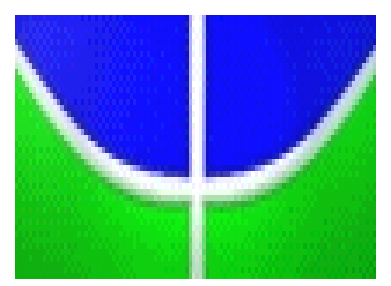

UNIVERSIDADE DE BRASÍLIA - UnB

INSTITUTO DE LETRAS - IL

DEPARTAMENTO DE LÍNGUAS ESTRANGEIRAS E TRADUÇÃO - LET

PROGRAMA DE PÓS-GRADUAÇÃO EM ESTUDOS DE TRADUÇÃO - POSTRAD

\title{
O FLORESCER DAS VOZES NA TRADUÇÃO DE PURPLE HIBISCUS,
} DE CHIMAMANDA NGOZI ADICHIE

FERNANDA DE OLIVEIRA MÜLLER

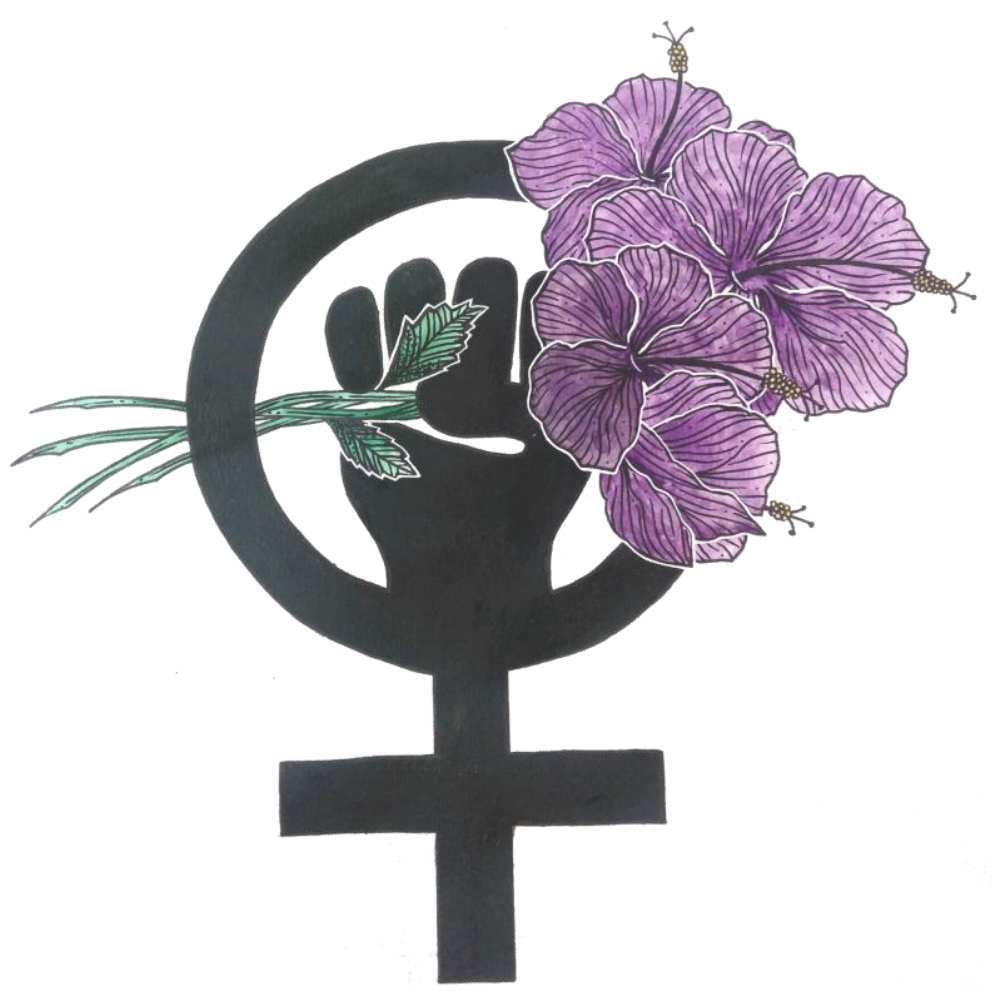

BRASÍLIA

MARÇO, 2017 


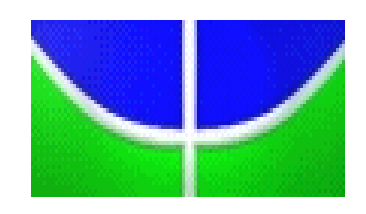

UNIVERSIDADE DE BRASÍLIA - UnB

INSTITUTO DE LETRAS - IL

DEPARTAMENTO DE LÍNGUAS ESTRANGEIRAS E TRADUÇÃO - LET PROGRAMA DE PÓS-GRADUAÇÃO EM ESTUDOS DE TRADUÇÃO POSTRAD

O FLORESCER DAS VOZES NA TRADUÇÃO DE PURPLE HIBISCUS, DE CHIMAMANDA NGOZI ADICHIE FERNANDA DE OLIVEIRA MÜLLER

\section{DISSERTAÇÃO DE MESTRADO EM ESTUDOS DA TRADUÇÃO}

BRASÍLIA

MARÇO, 2017 


\section{UNIVERSIDADE DE BRASÍLIA - UnB INSTITUTO DE LETRAS - IL}

DEPARTAMENTO DE LÍNGUAS ESTRANGEIRAS E TRADUÇÃO - LET

PROGRAMA DE PÓS-GRADUAÇÃO EM ESTUDOS DE TRADUÇÃO - POSTRAD

O FLORESCER DAS VOZES NA TRADUÇÃO DE PURPLE HIBISCUS, DE CHIMAMANDA NGOZI ADICHIE

\section{FERNANDA DE OLIVEIRA MÜLLER}

ORIENTADORA: PROF ${ }^{\text {a }}$ DRA. SABINE GOROVITZ

DISSERTAÇÃO DE MESTRADO EM ESTUDOS DA TRADUÇÃO

BRASÍLIA 
UNIVERSIDADE DE BRASÍLIA

INSTITUTO DE LETRAS - IL

DEPARTAMENTO DE LÍNGUAS ESTRANGEIRAS E TRADUÇÃO - LET

PROGRAMA DE PÓS-GRADUAÇÃO EM ESTUDOS DE TRADUÇÃO - POSTRAD

\title{
O FLORESCER DAS VOZES NA TRADUÇÃO DE PURPLE HIBISCUS, DE CHIMAMANDA NGOZI ADICHIE
}

\section{FERNANDA DE OLIVEIRA MÜLLER}

\begin{abstract}
Dissertação de Mestrado submetida ao Programa de Pós-Graduação em Estudos da Tradução, como parte dos requisitos necessários à obtenção do grau de mestra em Estudos da Tradução.
\end{abstract}

APROVADA POR:

PROF ${ }^{\mathrm{a}}$. DRA. SABINE GOROVITZ, POSTRAD/UnB

(ORIENTADORA)

PROF ${ }^{a}$. DRA. GERMANA HENRIQUES PEREIRA DE SOUSA, POSTRAD/UnB (EXAMINADORA INTERNA)

PROF $^{\text {a }}$ DRA. FERNANDA ALENCAR, POSLIT/UnB

(EXAMINADORA EXTERNA)

PROF ${ }^{\text {a }}$ DRA. SORAYA FERREIRA ALVES, POSTRAD/UnB (SUPLENTE) 


\section{REFERÊNCIA BIBLIOGRÁFICA E CATALOGAÇÃO}

MÜLLER, Fernanda de Oliveira. O florescer das vozes na tradução de Purple hibiscus, de Chimamanda Ngozi Adichie. Brasília: Departamento de Línguas Estrangeiras e Tradução, Universidade de Brasília, 2017, 107f. Dissertação de mestrado em Estudos da Tradução.

Documento formal, autorizando reprodução desta dissertação de mestrado para empréstimo, exclusivamente para fins acadêmicos, foi passado pela autora à Universidade de Brasília e acha-se arquivado na Secretaria do Programa. A autora reserva para si os outros direitos autorais, de publicação. Nenhuma parte desta dissertação de mestrado pode ser reproduzida sem a autorização por escrito da autora. Citações são estimuladas, desde que citada a fonte.

\section{FICHA CATALOGRÁFICA}

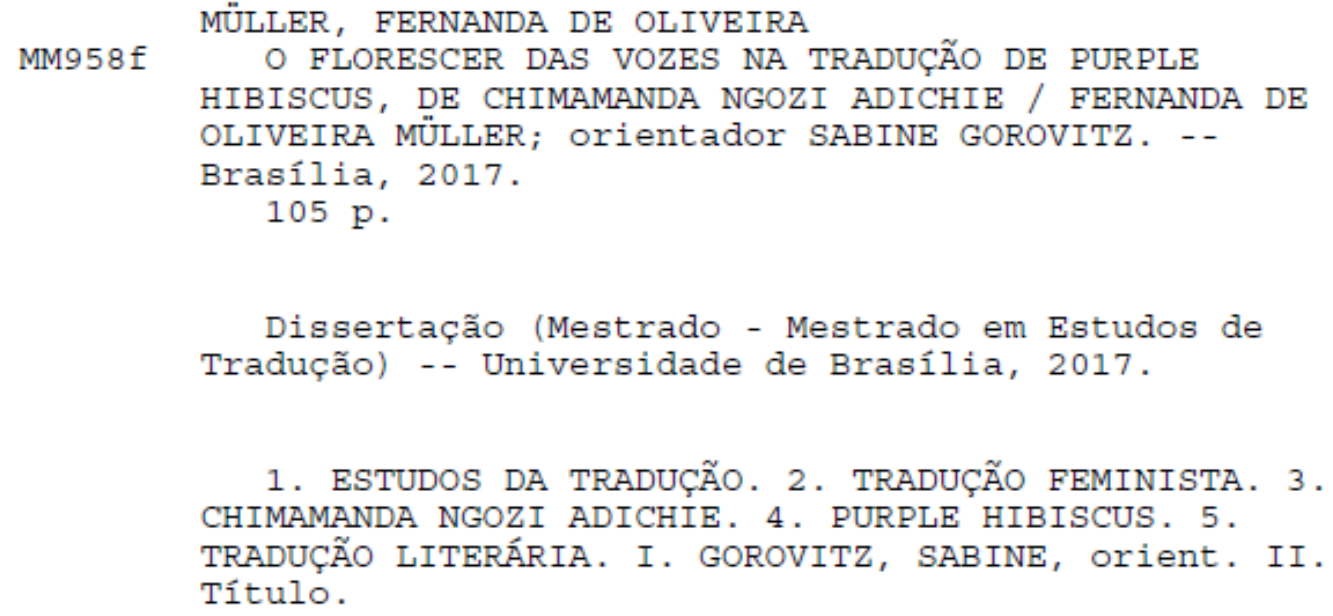


Para Melissa e Fábio

Que dão cor e perfume à minha vida. 


\section{AGRADECIMENTOS}

À Chimamanda, pelos livros que escreveu e pelos que ainda vai escrever, que tanto inspiram mulheres pelo mundo afora.

À tradutora Júlia Romeu, por meio de quem tantas leitoras brasileiras conheceram essa escritora fantástica. Obrigada por estar sempre disposta a colaborar com minha pesquisa.

À professora Sabine, orientadora querida. Obrigada por estar por perto, pronta a me atender em qualquer dia e horário. E por me apresentar à professora Fernanda e ao grupo de pesquisa Number 6, tão importantes na minha caminhada.

À Cláudia, amiga tão maravilhosa, sem quem esta dissertação não existiria. Obrigada por plantar a semente dos Estudos da Tradução no meu coração cheio de literatura, por me incentivar a fazer a inscrição, pelos milhares de livros, pela paciência infinita nas revisões, por me motivar e não me deixar desistir. Gratidão eterna.

Ao Fábio, companheiro de todas as horas, que acreditou em mim, quando nem eu mesma acreditava. Obrigada por cuidar de mim e da nossa Mel enquanto eu corria atrás deste sonho, e por fazer do nosso universo particular um lugar maravilhoso. Amo você.

À minha menina, minha Melissa. Doce Mel, que tantas vezes ouviu mamãe dizer peraí, quando estava em frente ao computador, e teve que esperar para brincar comigo. Minha parceira, minha flor, obrigada por existir. Você é uma grande menina e certamente se tornará uma grande mulher.

Aos meus pais, pela "casa da vovó": um lugar mágico de portas sempre abertas para a menina de mãe mestranda.

Às professoras, aos professores e colegas do Postrad, com quem aprendi tanto e compartilhei as dores e as delícias de ser uma pós-graduanda. 
God, when will you create a woman who will be fulfilled in herself, a full human being, not anybody's appendage? she prayed desperately.

(Buchi Emecheta, The Joys of Motherhood). 


\section{LISTA DE TABELAS}

Tabela 1: Exemplos de atitude feminista nos discursos 30

Tabela 2: Exemplos de discursos de Amaka 31

Tabela 3: Exemplos de discursos de Olanna 32

Tabela 4: Exemplos de discursos de Kainene 33

Tabela 5: Trechos do blog da personagem Ifemelu 34

Tabela 6: Referências aos hibiscos roxos 36

Tabela 7: Mescla de sujeitos do discurso 44

Tabela 8: Descrição da postura resignada de Beatrice 45

Tabela 9: Frequência de palavras do campo lexical do falar 47

Tabela 10: Frequência de palavras do campo lexical do olhar em Purple $\quad 47$ hibiscos

Tabela 11: Frequência de palavras do campo lexical do olhar em Hibisco roxo 48

Tabela 12: Linguagem do olhar entre Jaja e Kambili 49

Tabela 13: Linguagem do olhar entre Jaja e Kambili 50

Tabela 14: Linguagem do olhar entre Jaja e Kambili 50

Tabela 15: Verbo look away significando fuga 51

Tabela 16: Verbo look away significando fuga 51

Tabela 17: Encontro de olhares 51

Tabela 18: Fala de Kambili com o intuito de agradar o pai 52

Tabela 19: Diálogo entre Beatrice e Eugene 53

Tabela 20: Tosse forçada de Kambili 53

Tabela 21: Descrição do modo de falar de Ifeoma 53

Tabela 22: Kambili expressa seu desejo de falar 54

Tabela 23: Descrição do olhar de Amaka 54

Tabela 24: Descrição do olhar de Amaka 55

Tabela 25: Descrição do olhar de Amaka 55 
Tabela 26: Descrição do olhar e do falar de Ifeoma

Tabela 27: Verbos do campo lexical do falar cujo sujeito é Kambili 57

Tabela 28: Exemplos de desvio do olhar como atitude assertiva 57

Tabela 29: Verbo do campo lexical do olhar como atitude assertiva 58

Tabela 30: Linguagem do olhar entre Jaja e Kambili 58

Tabela 31: Verbo do campo lexical do olhar como atitude assertiva 59

Tabela 32: Kambili expressa seu desejo de falar 59

Tabela 33: Mudança dos verbos usados para introduzir a fala de Eugene $\quad 61$

Tabela 34: Início da conquista da voz de Beatrice $\quad 61$

Tabela 35: Linguagem corporal e do olhar de Kevin 61

Tabela 36: Kambili como sujeito de verbos do campo lexical do falar 62

Tabela 37: Silêncio libertador 63

Tabela 38: Liberdade de falar (ainda em processo) 63

Tabela 39: Liberdade de falar (ainda em processo) 63

Tabela 40: Olhar e falar indicando o trauma de Beatrice 63

Tabela 41: Verbos no futuro como sinal de esperança 64

Tabela 42: Descrição do ofertório $\quad 65$

Tabela 43: Mudança do sotaque de Eugene 66

Tabela 44: Uso do igbo em momentos de raiva 66

$\begin{array}{ll}\text { Tabela 45: Beatice canta em igbo } & 67\end{array}$

Tabela 46: Tratamento entre Ifeoma e Beatrice $\quad 67$

Tabela 47: Tratamento entre Amaka e Kambili 68

$\begin{array}{ll}\text { Tabela 48: Feitiço em igbo } & 68\end{array}$

Tabela 49: Confronto entre Ifeoma e Eugene $\quad 69$

Tabela 50: Fala de Beatrice após o aborto $\quad 82$

Tabela 51: Confronto entre mãe e filha 83

Tabela 52: Poligamia na cultura igbo $\quad 83$ 


\section{RESUMO}

Purple hibiscus, primeiro livro da escritora nigeriana Chimamanda Ngozi Adichie, é um romance de temática feminista sobre a conquista da própria voz e do rompimento com a submissão e o silêncio impostos pelo patriarcado, pela religião e pelo conservadorismo. Tomando por base as teorias da Tradução Feminista, sobretudo de Simon (1996) e Von Flotow (1997 e 2012), investigo de que forma as marcas de feminismo na obra foram abordadas na tradução para o português do Brasil. A pesquisa inicia-se pela biografia da escritora - sua conexão com a literatura póscolonial e militância feminista -, seguindo para os vários conceitos e vertentes do feminismo. Na sequência, apresento uma análise quali-quantitativa dos termos referentes aos campos lexicais do olhar e do falar no texto de partida, tomados como indicadores do desabrochar da liberdade, e proponho alternativas à tradução de Hibisco roxo, elaboradas com o intuito de reforçar as marcas feministas. Ao final, traço um histórico da Tradução Feminista, indicando novas tendências que estão a florescer. Este trabalho trata sobre a liberdade. Sobre vozes abafadas e inaudíveis que, aos poucos, começam a se fortalecer e a serem notadas, até aflorarem completamente. É uma pesquisa sobre a luta da mulher por independência e visibilidade, em uma sociedade patriarcal que, desde os primórdios, coloca-a em uma posição assessória, inferior e incompleta em si mesma. É sobre a liberdade do ato da tradução, da autonomia da tradutora para fugir da invisibilidade e da submissão, de manipular o texto e fazer sua voz ser ouvida pelo leitor. E é também sobre o processo de conquista da liberdade pelos personagens de Purple hibiscus, e de como essa conquista está associada à militância feminista de sua autora.

Palavras-chave: Estudos da Tradução; Tradução Feminista; Chimamanda Ngozi Adichie; Purple hibiscus; Tradução Literária. 


\begin{abstract}
Nigerian writer Chimamanda Ngozi Adichie's debut novel, Purple hibiscus, is a feminist-themed novel about the conquest of one's own voice and the break with submission and silence imposed by patriarchy, religion, and conservatism. Based on Feminist Translation theories, especially on Simon (1996) and Von Flotow (1997 and 2012), I investigate how the translator approached the feminist marks in the Brazilian Portuguese version. First, the research presents the writer's biography, underscoring her connection to postcolonial literature and feminist militancy. Next, the various concepts and strands of feminism are discussed. After that, I present a qualiquantitative analysis of terms belonging to the lexical fields look and speech in the starting text, considered to be indicators of the blooming of freedom. In an attempt to intentionally reinforce the feminist marks in the text, I present alternatives to that translation of Purple hibiscus. Finally, I provide a brief background of Feminist Translation, presenting new trends that are flourishing. This work is about freedom. It is about muffled and inaudible voices that, little by little, became louder, until they finally flourished. It is a research on the struggle of women for independence and visibility in a patriarchal society which, from the earliest stages, places women in an inferior and secondary position. It is about the freedom of translation and the autonomy of the translator to fight invisibility and submission and to manipulate the text in order to make his/her voice heard by the reader. And it is also about the liberation of Purple hibiscus oppressed characters, and the connections between their freedom and the author's feminist militancy.
\end{abstract}

Keywords: Translation Studies; Feminist Translation; Chimamanda Ngozi Adichie; Purple hibiscus; Literary Translation. 


\section{SUMÁRIO}

$\begin{array}{lc}\text { INTRODUÇÃO } & 14\end{array}$

CAPÍTULO 1 - BREAKING GODS: QUEBRANDO PARADIGMAS DA 18 MULHER E DA NIGÉRIA

1.1 Chimamanda Ngozi Adichie: biografia e produção literária 18

1.2 As mulheres de Chimamanda: a temática feminista nos romances 26

1.3 O florescer - o hibisco e a Nigéria 32

CAPÍTULO 2 - SPEAKING WITH OUR SPIRITS: A VOZ DAS 40 PERSONAGENS

2.1 A voz e o silêncio em Purple hibiscus: marcas feministas nas personagens $\quad 40$ e nos discursos

2.2 Igbo, inglês e o lugar de fala das mulheres $\quad 61$

CAPÍTULO 3 - THE PIECES OF GODS: (RE)CONSTRUINDO 69 SIGNIFICADOS

3.1 Feminismo, feminismo negro, womanism, Africana Womanism: várias $\quad 69$ mulheres, várias lutas

3.2 A tradução feminista e o empoderamento da tradutora 73

3.3 Translatress, translatrix, translator: problematizando o masculino 81 generalizante

3.4 A invisibilidade da tradutora no mercado editorial 84

CAPÍTULO 4 - A DIFFERENT SILENCE - THE PRESENT: 87

CONSIDERAÇÕES FINAIS

REFERÊNCIAS BIBLIOGRÁFICAS 94

APÊNDICE - ENTREVISTAS COM A TRADUTORA JÚLIA ROMEU 98

$\begin{array}{ll}\text { ANEXOS - IMAGENS } & 104\end{array}$

Imagem 1: Apresentação da cantora Beyoncé no 2014 MTV VMAs 104

Imagem 2: Chimamanda durante a Women's March on Washington 104

Imagem 3: Desfile de estreia de Maria Grazia Chiuri para Dior 105

Imagem 4: Anúncio da linha No. 7, da marca inglesa de cosméticos Boots 105 


\section{INTRODUÇÃO}

Este trabalho trata sobre a liberdade. Sobre vozes abafadas e inaudíveis que, aos poucos, começam a se fortalecer e a serem notadas, até aflorarem completamente. É uma pesquisa sobre a luta da mulher por independência e visibilidade, em uma sociedade patriarcal que, desde os primórdios, coloca-a em uma posição assessória, inferior e incompleta em si mesma. É sobre a liberdade do ato da tradução, da autonomia da tradutora para fugir da invisibilidade e da submissão, de manipular o texto e fazer sua voz ser ouvida pelo leitor. E é também sobre o processo de conquista da liberdade pelos personagens de Purple hibiscus, e de como essa conquista está associada ao feminismo de sua autora.

Chimamanda Ngozi Adichie é uma escritora nigeriana nascida em 1977, que, aos 19 anos, mudou-se para os Estados Unidos. É autora de três romances, um livro de contos e diversos ensaios e palestras, e sua produção é permeada por temas relacionados à liberdade: liberdade de seu país, em questões que se referem à busca de uma identidade na Nigéria pós-independência do Reino Unido, em 1960; liberdade para seu povo, com a oportunidade de resgatar suas raízes, que brotam das variadas etnias; e liberdade para as mulheres, que, historicamente, foram limitadas a ocupar um espaço secundário e subalterno, tanto na sociedade como na família e na própria História, agindo sempre como coadjuvantes de homens.

Em suas palestras e entrevistas, a escritora faz questão de deixar patente sua posição como feminista e ativista pelos direitos da mulher. Um dos discursos mais famosos, com quase três milhões de acessos no site YouTube, foi apresentado para o canal TEDx Euston em abril de 2013, intitulado We should all be feminists [Todos devemos ser feministas]. Na apresentação, que em 2014 foi publicada como livro, a escritora conclama a todos, homens e mulheres, a aderirem à proposta feminista. Defende um feminismo para o século XXI, libertador de todos os estereótipos que envolvem a questão de gênero e que luta contra a discriminação da mulher:

Algumas pessoas perguntam: "Por que a palavra feminista? Por que não dizer simplesmente que você defende os direitos humanos, ou algo assim?." Porque isso seria desonesto. É claro que o feminismo faz parte dos direitos humanos em geral - mas utilizar uma expressão tão vaga como "direitos humanos" seria negar o problema específico do gênero. Seria uma forma de fingir que não foram especificamente as mulheres que foram excluídas por séculos. Seria uma forma de negar que o problema de gênero tem como alvo as mulheres. Que o problema não é sobre ser humano, mas especificamente 
sobre ser mulher. Por séculos, os seres humanos foram divididos em dois grupos, e um grupo foi excluído e oprimido pelo outro. É justo que a solução para o problema leve isso em consideração. Alguns homens se sentem ameaçados pela ideia do feminismo. Eu acredito que isso aconteça por causa do modo como os meninos são criados, da insegurança que sentem quando não estão "naturalmente" na posição de controle, como homens. ${ }^{1}$

O romance de estreia da escritora, Purple hibiscus, publicado originalmente nos Estados Unidos em 2003, e, no Brasil, em 2011, com o título Hibisco roxo, também pode ser considerado um livro feminista. A narrativa gira em torno da descoberta da liberdade por uma adolescente nigeriana, e trata de temas como "patriarcalismo", "conservadorismo", "fundamentalismo religioso", "violência contra a mulher", "conflitos familiares" e "resistência feminina", inseridos no cenário da Nigéria póscolonial na década de 1980 .

Os acontecimentos na vida de Kambili - uma garota de 15 anos que vive com a mãe e o irmão sob a cerviz de um pai autoritário, católico conservador, que exerce abusos físicos e psicológicos sobre a família -, são narrados pela própria menina. Ao longo da história, ela descobre outra possibilidade de vida fora dos muros da mansão onde mora, ao viver uma realidade diferente na casa simples de sua tia Ifeoma, uma jovem viúva, professora, e de seus três filhos. Embates políticos e culturais também fazem parte dessa narrativa, cujos principais personagens são mulheres.

Beatrice, mãe de Kambili, assim como a menina, vive uma vida subjugada pelas regras de seu marido Eugene. Sofre calada a violência e a opressão do marido, que chegam a causar o aborto em mais de uma gestação. Ao mesmo tempo, tia Ifeoma e sua filha Amaka, que tem a mesma idade da adolescente, são mulheres livres e questionadoras que expressam o próprio pensamento e que acabam por influenciar as demais.

É o olhar de Kambili que mostra ao leitor as mudanças que ocorrem no país, na família e nela mesma. Trata-se de um Bildungsroman: termo da crítica literária que

\footnotetext{
${ }^{1}$ Discurso disponível no canal YouTube em: <https://www.youtube.com/watch?v=hg3umXU_qWc>. ["Some people ask: 'Why the word feminist? Why not just say you are a believer in human rights, or something like that?' Because that would be dishonest. Feminism is, of course, part of human rights in general - but to choose to use the vague expression 'human rights' is to deny the specific and particular problem of gender. It would be a way of pretending that it was not women who have, for centuries, been excluded. It would be a way of denying that the problem of gender targets women. That the problem was not about being human, but specifically about being a female human. For centuries, the world divided human beings into two groups and then proceeded to exclude and oppress one group. It is only fair that the solution to the problem acknowledge that. Some men feel threatened by the idea of feminism. This comes, I think, from the insecurity triggered by how boys are brought up, how their sense of self-worth is diminished if they are not 'naturally' in charge as men."] Esta e todas as outras traduções de textos críticos e teóricos são de minha autoria, exceto se expressamente informada a fonte.
} 
caracteriza o romance que expõe o desenvolvimento de um personagem desde a infância, retratando as transições e os conflitos, até seu amadurecimento, na idade adulta. Como explica Bailey (2005):

O gênero do Bildungsroman, [...] significa "romance de aprendizado" ou "romance de desenvolvimento". Tal aprendizado refere-se ao processo de formação psicológica, espiritual e social da personagem central da obra, geralmente narrado a partir de sua infância até o início da idade madura, quando a personagem se encontraria "formada", tendo terminado seu aprendizado de vida (BAILEY, 2005, p. 444).

É um romance sobre a conquista da própria voz e do rompimento com a submissão e o silêncio impostos pelo patriarcado, a religião e o conservadorismo - uma história sobre o florescer. A crítica feminista da autora está presente no registro usado, tanto nos diálogos quanto nas descrições - termos, expressões e palavras, escolhas lexicais e valor semântico -, que levantam questionamentos quanto aos papéis de homens e mulheres na sociedade e às relações de poder.

O objetivo principal da presente pesquisa é analisar, sob o viés das teorias da tradução feminista de Simon (1996), Von Flotow (1996 e 2012), entre outras, a tradução de Purple hibiscus para o português do Brasil, a fim de investigar de que forma o feminismo comparece, tanto por meio de marcas lexicais, como morfossintáticas.

Para tanto, busquei conhecer a fundo a escritora Chimamanda Ngozi Adichie, sua obra e sua militância feminista. Em seus romances e contos, a autora apresenta sua crítica à questão de gênero através das personagens: mulheres que, colocadas em situações de opressão sexista e patriarcal em diferentes contextos, apresentam sempre uma postura de resistência e fazem da sua voz e da sua atitude uma forma de questionamento do status quo e de empoderamento feminino.

Em seguida, destaquei os termos nos campos lexicais do olhar e do falar, em Purple hibiscus e Hibisco roxo, relacionados à voz e ao silêncio, os quais revelam o processo de conquista da liberdade das personagens. Realizei, então, um levantamento quantitativo, utilizando a ferramenta computacional AntConc versão 3.2.1, e uma análise qualitativa, comparando a tradução desses termos e detectando os "achatamentos", ocorridos em decorrência de uma tradução literal para, na sequência,

\footnotetext{
${ }^{2}$ Nesta pesquisa, faço uso do termo "achatamento" como uma metáfora do processo que a narrativa, originalmente tão rica em nuances e relevos, sofre ao ser traduzida de forma literal e rasa, tornando-se um terreno homogêneo, unidimensional e plano, perdendo muito do seu significado e da intenção primeira da autora em seu projeto literário.
} 
propor alternativas de tradução que mantenham as marcas feministas do texto de chegada e evite o empobrecimentos do texto.

Também busquei conhecer a tradutora Júlia Romeu e o contexto da tradução do romance no Brasil, a fim de observar em que medida as exigências do mercado editorial e as regras das editoras podem impedir a autonomia e a visibilidade da tradutora (ou do tradutor) no texto traduzido. A tradutora tem experiência na tradução de escritoras de língua inglesa como Jane Austen e Charlotte Brontë, e se considera feminista. Entretanto, em sua tradução não apresenta traços da manifestação de seu feminismo.

Finalmente, procurei investigar a importância da atividade tradutória na consolidação de movimentos feministas, as principais teóricas da Tradução Feminista (em especial Sherry Simon e Luise Von Flotow) e as tendências atuais de pesquisas nessa área.

Meu interesse pelo tema surgiu ao ler o romance Purple hibiscus e perceber a maneira como a autora apresenta sua crítica à questão de gênero. Como leitora contumaz da literatura de autoria feminina e admiradora de Chimamanda, fiquei intrigada sobre como essa militância comparece (ou não) na tradução para o português do Brasil, sobre quem seria a tradutora a fazer esse trabalho e qual seria seu projeto de tradução. Ao ler Hibisco roxo, percebi que a ideologia e a militância da autora, manifestadas tanto na narrativa quanto na forma literária, haviam sido reduzidas, "achatadas”, por uma tradução bastante literal. A partir daí, interessei-me pelas teorias da tradução feminista, que propõem um novo enfoque para o que é traduzido e para quem faz a tradução.

As correntes da tradução feminista não se propõem a prescrever uma forma única de traduzir. Ao contrário, propõem uma postura ativa das tradutoras, como um sujeito visível, que não se prende à letra do texto. Defendem, também, uma tradução consciente de modo que a biografia e a ideologia das autoras também possam se manifestar na tradução. Por isso, acredito que a presente pesquisa é de relevância, tanto para os Estudos da Tradução como para os Estudos Literários: porque a perspectiva de um sujeito-tradutor visível, livre para agir sobre o texto e com voz para falar ao leitor, pode fazer florescer diferentes leituras e releituras nessas duas áreas. 


\title{
CAPÍTULO 1: BREAKING GODS: QUEBRANDO PARADIGMAS DA MULHER E DA NIGÉRIA
}

\subsection{Chimamanda Ngozi Adichie: biografia e produção literária}

\author{
Geralmente, não associamos a ideia de sabedoria a principiantes, \\ mas aqui está uma nova escritora dotada do talento dos antigos \\ contadores de histórias. ${ }^{3}$
}

(Chinua Achebe, sobre Chimamanda)

A trajetória de Chimamanda Ngozi Adichie como escritora iniciou-se na Nigéria, ainda na adolescência. Nascida em 15 de setembro de 1977, na cidade de Abba, estado de Anambra, sul da Nigéria, de etnia Igbo, ${ }^{4}$ passou a infância e a adolescência em Nsukka, cidade universitária no estado de Enugu, no sudeste do país, onde seu pai, James Nwoye Adichie, trabalhou como professor de Estatística na Universidade da Nigéria, e sua mãe, Grace Ifeoma Adichie, era secretária.

Durante os anos de escola, recebeu prêmios acadêmicos e publicou seus primeiros textos: uma coletânea de poemas, Decisions [Decisões], em 1997, e uma peça de teatro, intitulada For love of Biafra [Por amor a Biafra], em 1998, ambos sob o pseudônimo de "Amanda N. Adichie". Cursou Medicina na Universidade da Nigéria por um ano e meio. Nesse período, foi editora da revista The Compass, publicada pelos alunos.

Aos 19 anos, Chimamanda recebeu uma bolsa de estudos da Drexel University, na Filadélfia, Estados Unidos, para o curso de Comunicação. Depois, transferiu-se para a Eastern Connecticut State University, onde estudou Comunicação e Ciência Política. Lá, escrevia artigos para a revista da Universidade, Campus Lantern. Formou-se em 2001 com distinção máxima - summa cum laude - e concluiu o Mestrado em Escrita Criativa na Johns Hopkins University, Baltimore, Maryland. Também tem mestrado em Estudos Africanos, pela Universidade de Yale, e recebeu financiamentos de universidades, como Princeton e Harvard para pesquisa e produção de seus livros.

\footnotetext{
${ }^{3}$ Frase atribuída a Chinua Achebe, publicada na capa da primeira edição britânica de Half of a yellow sun. Disponível em: <http://www.premiumtimesng.com/arts-entertainment/108378-chinuaachebeat82we-remember-differently-by-chimamanda-ngozi-adichie.html>. ["We do not usually associate wisdom with beginners, but here is a new writer endowed with the gift of ancient storytellers".]

${ }^{4}$ Há duas grafias possíveis para a denominação da etnia: Ibo e Igbo. Nesta pesquisa, optei por utilizar a grafia igbo, que também foi a utilizada nas obras de Chimamanda em português brasileiro.
} 
Seu primeiro romance, Purple hibiscus, foi publicado em 2003 nos Estados Unidos por uma pequena editora no estado da Carolina do Norte, Algonquin Books, e em 2004, no Reino Unido e na Nigéria. A obra foi aclamada pela crítica e recebeu diversos prêmios, sendo um dos principais o Commonwealth Writers' Prize for Best First Book, ${ }^{5}$ em 2005, quando foi reconhecido como a melhor obra-prima daquele ano entre os países do Commonwealth. O romance já foi traduzido para 20 línguas, ${ }^{6}$ dentre as quais o português brasileiro, em 2011.

Em 2006, o segundo romance, Half of a yellow sun [Meio sol amarelo], foi publicado por editoras dos Estados Unidos, do Reino Unido e da Nigéria; e também foi sucesso de crítica, sendo incluído na lista dos 100 livros mais notáveis do ano de 2006 pelo jornal The New York Times. Recebeu, em 2007, o Orange Prize de ficção, prêmio entregue anualmente ao melhor romance escrito por uma mulher em língua inglesa, e ao qual Purple hibiscus havia sido indicado anteriormente. O romance foi traduzido para 25 línguas, e chegou ao Brasil em 2008. Também foi adaptado para o cinema em 2013, em uma parceria Nigéria-Estados Unidos. A adaptação do filme agradou a escritora, que, ao autorizar a adaptação, estabeleceu como pré-requisito a filmagem in loco na Nigéria, local onde se passa a trama. ${ }^{7}$

Seu terceiro livro, The thing around your neck [A coisa à volta do teu pescoço], publicado em 2009, é uma coleção de 12 contos publicados em jornais e revistas diversos. Já foi traduzido para 10 línguas e foi um dos finalistas ao prêmio de escritores do Commonwealth de 2010. Até o momento, não há uma edição em português brasileiro, somente uma versão portuguesa.

Em 2013, Chimamanda publicou seu terceiro romance, Americanah, que foi selecionado pelo New York Times como um dos 10 melhores livros de 2013, além de estar na lista dos melhores de 2013 do canal britânico BBC e do jornal The Guardian. ${ }^{8}$

\footnotetext{
${ }^{5}$ Prêmio oferecido anualmente pela Commonwealth Foundation, entre 1987 e 2012, com a finalidade de incentivar novos escritores de ficção e divulgar sua literatura para outros países, nas categorias Melhor Livro e Melhor Livro de Estreia. Em 2012, passou a ser denominado Commonwealth Book Prize, com prêmio no valor de 10 mil libras para Melhor Livro de Estreia, e Commonwealth Short Story Prize, no valor de 5 mil libras para o melhor conto. Desde 2013, só permanece a categoria para contos. (Disponível em: <http://www.commonwealthwriters.org/commonwealth-book-prize/>.)

6 Estatísticas atualizadas até janeiro de 2017, fornecidas pelo site <http://www.cerep.ulg.ac.be/adichie/cnaprim.html\#translation>.

${ }^{7}$ Opinião de Chimamanda durante entrevista à revista Salt, em 27 de fevereiro de 2014. (Disponível em: <http://www.saltmagazine.org/chimamanda-ngozi-adichie/>. Acesso em 01 de fevereiro de 2017.)

${ }^{8}$ Disponível em: <http://www.newsexpressngr.com/news/3835-Chimamanda-Adichies-AMERICANAHmakes-New-York-Times-BBC-Best-Book-of-the-Year>.
} 
A produção de um filme baseado no romance estaria em fase de negociação, mas ainda sem previsão de lançamento 9 .

Em 2014, seu discurso apresentado em dezembro de 2012 na conferência TEDxEuston, com mais de três milhões de acessos no canal YouTube, ${ }^{10}$ intitulado We should all be feminists, foi publicado como livro e traduzido para cinco línguas.

No Brasil, até janeiro de 2017, ${ }^{11}$ mais de 60 mil livros da escritora, traduzidos para o português do Brasil, todos publicados pela editora Companhia das Letras, já foram vendidos. Hibisco roxo, Americanah e Sejamos todos feministas (este último o livro mais vendido de Chimamanda no Brasil) estão na quinta reimpressão, e Meio sol amarelo está na terceira.

Anchieta e Pereira (2017) levantam algumas possibilidades que justificariam o curto período entre o lançamento das obras da escritora e a publicação das traduções no Brasil, o que não acontecia no passado com obras de escritores do continente africano: uma delas seria o sucesso de vendas e de crítica e as premiações recebidas em âmbito internacional, que podem ter atraído o interesse do mercado editorial brasileiro. Outra seria a Lei $n^{0} 10.639 / 2003$, alterada pela Lei $n^{0} 11.645 / 2008$, que torna obrigatório o ensino da história e cultura afro-brasileira e africana em todas as escolas, públicas e particulares, do ensino fundamental até o ensino médio.

Esta lei, que é um instrumento importante para a luta contra o racismo, pretende enfatizar a herança africana como um dos componentes mais relevantes da sociedade brasileira. Além de razões econômicas que fomentaram o investimento por editoras em diferentes cenas literárias, esta lei também aumentou a curiosidade, o interesse e a necessidade de publicar autores africanos $^{12}$ (ANCHIETA; PEREIRA, 2017, p. 4).

Ao pesquisar sobre a vida de Chimamanda, percebe-se que a literatura, a produção de textos, sempre estiveram presentes, mesmo antes de abraçar a carreira de escritora. Ainda criança, vivia em uma casa de intelectuais, com abundância de livros. A menina lia tanto que sua mãe, em uma entrevista, afirmou que ela havia sido criada para

\footnotetext{
9 Fonte: https://www.theguardian.com/film/2014/jun/06/lupita-nyong-o-brad-pitt-americanahchimamanda-ngozi-adichie (Acesso em 01 de fevereiro de 2017).

${ }^{10}$ Disponível em: 〈https://www.youtube.com/watch?v=hg3umXU_qWc〉.

${ }^{11}$ Informação fornecida pela editora Cia. das Letras por e-mail, em 14 de janeiro de 2017.

12 "This law, which is an important instrument for the fight against racism, intends to emphasise African heritage as one of the most relevant constituents of Brazilian society. Besides economic reasons that fostered investment by publishing houses in different literary scenes, this law has also enhanced curiosity, interest and the need to publish African authors."
} 
"ser uma devoradora de livros". ${ }^{13}$ Também criava e contava suas próprias histórias desde os 7 anos, como conta na sua palestra The danger of a single story (traduzida para o português como "O perigo de uma única história"). ${ }^{14} \mathrm{E}$ durante os anos escolares escrevia contos e poemas que lhe deram reconhecimento:

Escrever não é sobre fama. (...) É sobre amar contar histórias. Quando eu era uma menina, eu enchia meus livros escolares com histórias. Eu sempre escrevi, sempre foi o meu primeiro amor, e, mesmo que eu nunca tivesse vendido um único livro, eu ainda estaria escrevendo. ${ }^{15}$

Mesmo assim, quando chegou o momento de escolher o curso universitário, a opção foi por seguir a tradição cultural de seu país e ingressar em um curso conservador, almejado por toda família nigeriana que tivesse condições de dar aos filhos uma profissão promissora, que garantiria ascensão social e status. Então, da mesma forma que seus irmãos mais velhos, que cursaram Engenharia, Medicina, Farmácia, Chimamanda ingressou na faculdade de Medicina na Universidade da Nigéria.

Mas, mesmo durante o curso, a produção escrita estava presente. Chimamanda escrevia para a revista dos alunos e continuava a mostrar seu talento. Até que, com ousadia, inscreveu-se para concorrer a uma bolsa de estudos nos Estados Unidos.

Em entrevista ao jornal britânico The Guardian, em 2014, ela narra como foi recebida por seus pais a notícia de que não estava satisfeita e desejava deixar a Nigéria para estudar Comunicação nos Estados Unidos. Seus pais, segundo ela, são pessoas progressistas e, apesar de perplexos no primeiro momento, concordaram. ${ }^{16}$

\footnotetext{
13 "We raised her a bookworm." Fala de Grace Ifeoma Adiche, em entrevista para o jornal This Day Online, em 25 de setembro de 2004. Disponível em <http://www.cerep.ulg.ac.be/adichie/cnasecond.html>.

14 Palestra apresentada em julho de 2009. Disponível em: <https://www.ted.com/talks/chimamanda_adichie_the_danger_of_a_single_story?language=pt-br $>$.

${ }^{15}$ Entrevista disponível em: <http://www.saltmagazine.org/chimamanda-ngozi-adichie/>. ["Writing is not about fame, she said firmly, It's all about a love for storytelling. As a little girl I'd fill up my school books with stories. I've always been writing, it's always been my first love, and even if I'd never sold one book - I'd still be writing"'].

16 “They thought I was slightly strange, but my parents are quite lovely; they're progressive. Still, it is a standing joke in the family that I say to them: 'The only reason you supported me is because my sister was already a doctor.' If not, I think they would have said, nobody leaves medical school, and especially not for reasons such as 'I'm not happy"'. (Disponível em: <https://www.theguardian.com/books/2014/mar/21/chimamanda-ngozi-adichie-interview>).

["Eles me achavam um pouco estranha, mas meus pais são muito amáveis, são progressistas. Mesmo assim, tem uma velha piada na minha família, que eu digo pra eles: 'A única razão por que vocês me apoiaram é porque minha irmã já era médica.' Se não fosse, eu acho que eles teriam dito, ninguém deixa a faculdade de Medicina, muito menos por motivos como 'Eu não estou feliz'”]
} 
A própria Chimamanda afirmava que um facilitador para que sua decisão fosse bem-sucedida foi o fato de que sua irmã já havia se formado em Medicina e já morava nos Estados Unidos. Então, o dever social, a cobrança cultural de cumprir o protocolo e ter filhos médicos já havia sido cumprida. Assim, a responsabilidade que se colocava sobre ela, que era a quinta de seis filhos, era menor.

A escritora passou quatro anos ininterruptos nos Estados Unidos, período durante o qual não visitou a Nigéria e passou por diversas situações de choque cultural. Muitas dessas experiências foram adaptadas para seus romances e vividas por seus personagens, como o estranhamento dos norte-americanos diante do contraste entre uma jovem da Nigéria e os estereótipos de fome e exotismo sobre a população do continente africano: a questão racial nos Estados Unidos, a migração de jovens nigerianos para outros continentes - a Diáspora - e a visão que os próprios nigerianos têm daqueles que deixam o país e retornam:

\begin{abstract}
Atualmente, Chimamanda vive nos Estados Unidos com seu esposo e filha, e na Nigéria, para onde viaja frequentemente e ministra, anualmente, uma oficina de escrita criativa. Ela tem se tornado uma celebridade mundialmente conhecida, não apenas por sua obra literária, mas por seu engajamento em questões humanitárias e de direitos das mulheres. Suas entrevistas, palestras e discursos têm milhares de acessos na internet e ela é considerada a mulher africana mais influente do mundo na atualidade. ${ }^{17}$
\end{abstract}

A visibilidade de Chimamanda como ativista feminista teve alcance mundial após a publicação no YouTube do discurso We should all be feminists. Uma parte dele foi incorporada à música "Flawless", da cantora norte-americana Beyoncé, em 2013 (Imagem 1). A popularidade de Chimamanda cresceu rapidamente após esse episódio, bem como a procura da imprensa internacional por entrevistas sobre o assunto. Mas a escritora manifestou que a importância dada por jornalistas ao fato foi muito além do que ela mesma considera. Seu objetivo é dar entrevistas como escritora, falar de suas obras e seus temas, e não se envolver em polêmicas do mundo das celebridades. ${ }^{18}$ Apesar de ter autorizado o uso de sua fala e de reconhecer que o papel da cantora pop na discussão sobre feminismo é importante para dar visibilidade à causa, seu feminismo e o de Beyoncé não são o mesmo:

17 Disponível em: <http://edition.cnn.com/2016/10/19/africa/chimamanda-adichie-influence-africa/> . (Acesso em 01 de fevereiro de 2017)

18 Entrevista para o jornal holandês Volkskrant, em outubro de 2016. Disponível em: <http://www.volkskrant.nl/boeken/ngozi-adichie-beyonce-s-feminism-isn-t-my-feminism a4390684/>. (Acesso em 01 de fevereiro de 2017) 
Ela retrata uma mulher responsável por seu próprio destino, que faz as coisas do seu jeito, e ela tem girl power. Estou convencida disso. Mesmo assim, seu tipo de feminismo não é o meu. É o tipo que, ao mesmo tempo, dá muito espaço à necessidade dos homens. Eu acho que os homens são lindos, mas eu não acho que as mulheres devem relacionar tudo o que fazem aos homens: "Ele me machucou?" "Vou perdoá-lo?" "Ele colocou um anel no meu dedo?" As mulheres são muito condicionadas a relacionar tudo com os homens. ${ }^{19}$

É exatamente essa proposta de pensar um feminismo para além dos homens que não propõe um confronto entre sexos, mas, sim, a problematização de toda a questão de gênero - o cerne de toda a produção de Chimamanda. Em seus livros, entrevistas, palestras, a principal mensagem é a da igualdade entre homens e mulheres. Tanto no que se refere a cobranças sociais - como a importância dada ao casamento e às responsabilidades de cuidados da casa e dos filhos - como na igualdade de oportunidades, em âmbito profissional e econômico - como a chance de não apenas poderem ingressar em qualquer carreira, mas também de galgarem cargos de chefia.

Em dezembro de 2015, uma cópia do livro We should all be feminists foi distribuída para cada adolescente no ensino médio da Suécia, numa iniciativa das organizações Swedish Women's Lobby, da editora Albert Bonniers, escritório sueco das Nações Unidas, The Order of the Teaspoone Unizon. A distribuição dos exemplares por essas instituições demonstra a preocupação do país em promover a igualdade de gênero e combater o preconceito, e também o alcance e a importância da escritora na atualidade.

Em 2016, Chimamanda publicou artigos e falou abertamente sobre as eleições presidenciais nos Estados Unidos e o avanço que significaria a eleição de uma mulher para presidir o país. Após o resultado, com o anúncio da vitória de Donald Trump, continuou a se manifestar, publicando uma carta de agradecimento à ex-primeira-dama Michelle Obama e uma crônica sobre a posse do novo presidente, em um diálogo entre Trump, a nova primeira-dama Melania e a filha. No dia seguinte à posse de Trump, em 21 de janeiro de 2017, participou da Women's March on Washington, marcha que

19 Disponível em: <http://www.volkskrant.nl/boeken/ngozi-adichie-beyonce-s-feminism-isn-t-myfeminism a4390684/>. ["She portrays a woman who is in charge of her own destiny, who does her own thing, and she has girl power. I am very taken with that. Still, her type of feminism is not mine, as it is the kind that, at the same time, gives quite a lot of space to the necessity of men. I think men are lovely, but I don't think that women should relate everything they do to men: "did he hurt me", do "I forgive him", did "he put a ring on my finger"? We women are so conditioned to relate everything to men."] 
concentrou milhares de mulheres em Washington, D.C., contra as opiniões sexistas do presidente eleito (Imagem 2).

Mesmo com toda a visibilidade proporcionada pela mídia, Chimamanda busca ao máximo preservar sua privacidade. Em julho de 2016, durante uma entrevista, comentou com o jornalista do Financial Times que havia dado à luz uma menina. Porém, recusou-se a dar detalhes sobre a gravidez, o nascimento e até mesmo o nome da criança. Segundo ela, não por querer esconder, mas por desejar manter esse assunto na esfera privada. E por não querer seguir a tendência moderna de as mulheres terem que mostrar uma atuação performática da gravidez e da maternidade, o que nunca é esperado dos homens quanto à paternidade. ${ }^{20}$

Em outubro de 2016, Chimamanda publicou, em sua página oficial do Facebook, uma carta endereçada a uma mulher de nome "Ijeawele", intitulada "Dear Ijeawele, or a feminist manifesto in fifteen suggestions". ${ }^{21}$ No texto ficcional, ela dá dicas a uma amiga que acabou de ter um bebê - uma menina de nome Chizalum - sobre como criar a criança para que se torne uma feminista. Ela incentiva a mãe a falar com a filha sobre a divisão de tarefas domésticas, papéis de gênero, relacionamentos amorosos, dignidade, respeito, opressão, padrões culturais e sociais, diversidade, entre outros. A publicação teve grande repercussão, e foi, por muitos, interpretada como um manifesto da própria escritora sobre o tipo de criação que pretende dar à filha.

Essa posição independente e autônoma da mulher, defendida por Chimamanda, tem sido explorada, recentemente, pela publicidade, o que tem levado a uma série de críticas por outras feministas.

No ano de 2016, a escritora assistiu a um desfile no Paris Fashion Week, ocasião em que o DJ do evento tocou o discurso We Should All Be Feminists, enquanto uma modelo desfilava na passarela vestindo uma camiseta com a mesma frase (Imagem 3). Tratava-se da coleção da estilista italiana Maria Grazia Chiuri, a primeira mulher a se tornar diretora de criação da marca Dior.

\footnotetext{
20 Disponível em: <http://jezebel.com/chimamanda-ngozi-adichie-quietly-gave-birth-refused-to1783171806>.

${ }^{21}$ Disponível em: <https://www.facebook.com/chimamandaadichie/posts/10154412708460944>. O texto, em formato de livro, foi lançado em 07 de março de 2017, em inglês, pela editora canadense Knopf e pela inglesa Fourth Estate, e no Brasil, pela Cia. das Letras, sob o título Para educar crianças feministas - um manifesto (tradução de Denise Bottman).
} 
A escritora foi criticada por permitir que a frase, um lema de igualdade e uma conclamação a que homens e mulheres venham a aderir ao feminismo, esteja sendo usada como produto comercial. Principalmente por se tratar de uma empresa tão poderosa da indústria da moda, que impõe padrões de beleza inatingíveis para mulheres comuns, sobretudo quanto ao peso. Igualmente inacessível para a grande maioria é o preço da camiseta, que é vendida por 500 Euros.

Em dezembro do mesmo ano, a marca de cosméticos Boots, do Reino Unido, passou a estampar Chimamanda como a modelo de seus anúncios da linha No.7, que também acompanham frases de seus discursos sobre a beleza e o uso de maquiagem (Imagem 4).

Mais uma vez, as críticas foram feitas no sentido de reprovar a atitude da escritora, que estaria associando sua imagem a produtos que servem para impor padrões de beleza e incentivarem mulheres a recorrerem a meios artificiais para disfarçarem e ocultarem características físicas consideradas como defeitos.

Chimamanda afirma que o uso de maquiagem que ela propõe não está relacionado a regras ou à moda, mas ao bem-estar e à vontade da própria mulher, que pode ter a opção de variar sua aparência e realçar os atributos que mais lhe agradam, sem se preocupar em agradar a homens ou a se encaixar em um padrão. Isso agradou parte do público, que apoiou a campanha, por ter uma mulher fora dos padrões tradicionais - de modelo branca, magra, de olhos claros - em seus anúncios. Mas, outra parte do público passou a publicar comentários negativos nas redes sociais e a criticar a escritora.

A questão que se coloca é a da "representatividade". Para as perguntas "Até que ponto uma nigeriana que emigrou aos 19 anos pode representar a Nigéria?”, “Até que ponto uma mulher negra que vive em uma condição econômica confortável experimenta situações de racismo e machismo em seu cotidiano?", “Até que ponto uma mulher negra, com traços finos e diferentes da maior parte das negras, e que usa roupas e acessórios elegantes, representa a aparência do todo?”, não há respostas, e as opiniões sobre o tema se dividem.

Polêmicas à parte, não há como negar que Chimamanda não é um mero produto midiático. A escritora tem, indiscutivelmente, um papel importante na literatura de autoria feminina na atualidade, bem como na literatura africana de língua inglesa e póscolonial. 


\subsection{As mulheres de Chimamanda: a temática feminista nos romances}

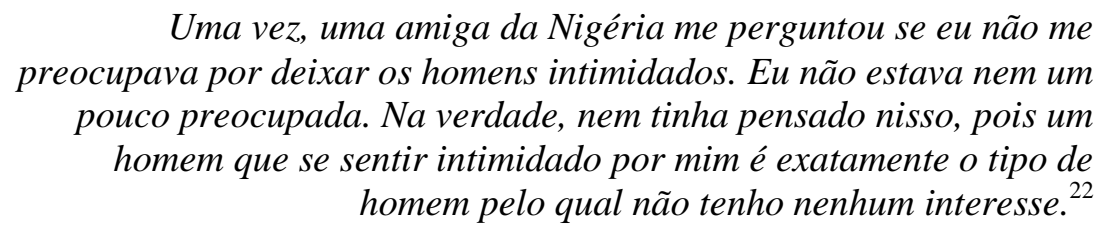

(Adichie, 2013)

Os três romances de Chimamanda, Purple hibiscus, Half of a yellow sun e Americanah são protagonizados por mulheres. A temática do "empoderamento feminino" é recorrente em toda a sua obra, inclusive nos contos de The thing around your neck. Todas elas rompem, de maneiras diferentes, os estereótipos de mulheres submissas, dependentes e frágeis. São mulheres fortes, oriundas da Nigéria, a maioria de etnia Igbo, decididas, que não têm uma atitude passiva, como esperada nos moldes tradicionais.

Muitas das características dessas personagens remetem à vida da escritora, e têm relação com sua própria experiência como mulher, negra, de origem africana, vivendo nos Estados Unidos como imigrante.

Em Purple hibiscus, as mulheres de postura feminista, que fazem o contraponto ao personagem Eugene - homem, opressor, violento e autoritário -, são a irmã dele, Ifeoma, e a sobrinha, Amaka.

Ifeoma é uma professora universitária, viúva, que cria sozinha seus três filhos, Amaka, Obiora e Chima, em meio a dificuldades financeiras, na cidade de Nsukka. A personagem pode ser considerada uma homenagem à mãe da escritora, Grace Ifeoma, que conseguiu se tornar a primeira mulher a ocupar o cargo de secretária na Universidade da Nigéria, em Nsukka, o que, à época, também foi um sinal de ousadia. O livro é dedicado aos pais da escritora, James e Ifeoma Adichie.

Ifeoma questiona os padrões sociais e culturais da sociedade nigeriana, e não tem medo de discordar, enfrentar e mostrar o seu ponto de vista sobre casamento,

\footnotetext{
${ }^{22}$ Retirado do discurso We should all be feminists, publicado no canal YouTube, em 2013; disponível em: <https://www.youtube.com/watch?v=hg3umXU_qWc>. [“A Nigerian acquaintance once asked me if I was worried that men would be intimidated by me. I was not worried at all. In fact it had not occurred to me to be worried because a man who will be intimidated by me is exactly the kind of man I would have no interest in."]
} 
religião, e mesmo sobre a situação política do país. Na Tabela $1,{ }^{23}$ pode-se ver alguns trechos de falas da personagem que demonstram essa postura feminista: Ifeoma almeja ascensão profissional e financeira, mas quer conseguir por seus próprios méritos e não por um casamento. Ela critica o governo e se mostra consciente e ativa no questionamento à situação política de seu país.

Tabela 1: Exemplos de atitude feminista nos discursos em Purple hibiscus e Hibisco roxo

\begin{tabular}{|c|c|}
\hline Purple hibiscus & Hibisco roxo (tradução de Júlia Romeu) \\
\hline $\begin{array}{l}\text { "Nwunye } m \text {, sometimes life begins when } \\
\text { marriage ends." (p. 39) }\end{array}$ & $\begin{array}{l}\text { - Nwunye m, algumas vezes a vida começa } \\
\text { quando o casamento termina. (p. 39) }\end{array}$ \\
\hline $\begin{array}{l}\text { "Look what this military tyrant is doing to our } \\
\text { country." (p. 40) }\end{array}$ & $\begin{array}{l}\text { - Veja o que esse tirano militar está fazendo } \\
\text { com o nosso país. (p. 39) }\end{array}$ \\
\hline $\begin{array}{l}\text { "My spirit will intercede for you, so that } \\
\text { Chukwu will send a good man to take care of } \\
\text { you and the children." } \\
\text { "Let your spirit ask Chukwu to hasten my } \\
\text { promotion to senior lecturer, that is all I ask," } \\
\text { Aunty Ifeoma said. (p. 43) }\end{array}$ & $\begin{array}{l}\text { - Meu espírito vai interceder em seu favor, } \\
\text { para que Chukwu mande um bom homem para } \\
\text { tomar conta de você e das crianças. } \\
\text { - Seu espírito que peça a Chukwu para } \\
\text { acelerar minha promoção a professora sênior, } \\
\text { é só isso que eu quero - disse tia Ifeoma. (p. } \\
\text { 43) }\end{array}$ \\
\hline $\begin{array}{l}\text { "We cannot sit back and let it happen, } m b a \text {. } \\
\text { Where else have you heard of such a thing as a } \\
\text { sole administrator in a university?" (p. 107) }\end{array}$ & $\begin{array}{l}\text { - A gente não pode cruzar os braços e permitir } \\
\text { que isso aconteça, mba. Onde já se viu ter uma } \\
\text { universidade com apenas um administrador? } \\
\text { (p. 111) }\end{array}$ \\
\hline
\end{tabular}

No apartamento de Ifeoma, "igualdade" e "liberdade" são palavras de ordem. Apesar de católica, a família respeita e preserva a religião tradicional - pré-colonial. A mãe coordena a rotina da casa, e todos têm obrigações nas tarefas domésticas, até mesmo Chima, o filho mais novo, de 7 anos (p. 77). Todos são livres para expressar suas opiniões e também para argumentar e discordar. E a mãe é atenta a tudo, como um técnico que observa a performance do seu time após treiná-lo, incentivando a autonomia de ação e pensamento dos filhos.

A filha de Ifeoma, Amaka, é uma adolescente segura de si, questionadora e desafiadora. No seu estilo de agir, de falar, e até na sua aparência, demonstra confiança e ousadia. Amaka questiona a atitude servil de tentar imitar e considerar a cultura, a religião, a língua do colonizador da Nigéria, o inglês, superior. Ela mescla a religião católica com a religião originalmente praticada pelos Igbos, assim como mescla a língua

\footnotetext{
${ }^{23}$ Ao longo do trabalho, as citações do texto de partida serão apresentadas em tabela, com a tradução publicada em português no Brasil, mesmo quando não se tratar de análise de tradução dos trechos selecionados. Os trechos em destaque são grifos meus. Optei por esta forma com o objetivo de auxiliar o leitor que não tenha conhecimento profundo da língua inglesa, mas se interesse pelo tema tratado.
} 
inglesa com o igbo em sua fala e prefere bandas nigerianas ao produto cultural importado dos Estados Unidos (Tabela 2).

Tabela 2: Exemplos de discursos de Amaka

\begin{tabular}{|c|c|}
\hline Purple hibiscus & Hibisco roxo (tradução de Júlia Romeu) \\
\hline $\begin{array}{l}\text { "I listen mostly to indigenous musicians. } \\
\text { They're culturally conscious; they have } \\
\text { something real to say. Fela and Osadebe and } \\
\text { Onyeka are my favorites. Oh, I'm sure you } \\
\text { probably don't know who they are, I'm sure } \\
\text { you're into American pop like other } \\
\text { teenagers." (p. 60) }\end{array}$ & $\begin{array}{l}\text { - Eu quase só ouço músicos nativos. Eles são } \\
\text { socialmente conscientes; têm algo real a dizer. } \\
\text { Fela, Osadebe e Onyeka são os meus } \\
\text { preferidos. Aposto que você nunca ouviu falar } \\
\text { deles, aposto que gosta de pop americano } \\
\text { como os outros adolescentes. (p. 60). }\end{array}$ \\
\hline $\begin{array}{l}\text { "Interesting. So now rich people can't decide } \\
\text { what to do day by day, they need a schedule to } \\
\text { tell them."(p. 63) }\end{array}$ & $\begin{array}{l}\text { - Interessante. Então gente rica não consegue } \\
\text { decidir o que fazer todo dia, precisa de um } \\
\text { horário. }\end{array}$ \\
\hline $\begin{array}{l}\text { "Besides, it's about time Our Lady came to } \\
\text { Africa. Don't you wonder how come she } \\
\text { always appears in Europe? She was from the } \\
\text { Middle East, after all." (p. 69) }\end{array}$ & $\begin{array}{l}\text { - Além disso, já está mais do que na hora de } \\
\text { Nossa Senhora aparecer na África. Você não } \\
\text { acha estranho ela só aparecer na Europa? } \\
\text { Afinal de contas ela era do Oriente Médio. (p. } \\
\text { 70) }\end{array}$ \\
\hline $\begin{array}{l}\text { "But what's the point, then?" Amaka said to } \\
\text { Father Amadi, as if she had not heard her } \\
\text { mother. "What the church is saying is that } \\
\text { only an English name will make your } \\
\text { confirmation valid. 'Chiamaka' says God is } \\
\text { beautiful. 'Chima' says God knows best, } \\
\text { 'Chiebuka' says God is the greatest. Don't } \\
\text { they all glorify God as much as 'Paul' and } \\
\text { 'Peter' and 'Simon"?' (p. 130) }\end{array}$ & $\begin{array}{l}\text { - Mas então qual é o objetivo? - perguntou } \\
\text { Amaka a padre Amadi, como se não houvesse } \\
\text { escutado o que sua mãe dissera. - O que a } \\
\text { Igreja está dizendo é que só um nome inglês } \\
\text { torna válida a nossa crisma. O nome } \\
\text { "Chiamaka" diz que Deus é belo. "Chima" diz } \\
\text { que Deus sabe mais, "Chiebuka" diz que Deus } \\
\text { é o melhor. Por acaso eles não glorificam } \\
\text { Deus da mesma forma que "Paul", "Peter" e } \\
\text { "Simon"? (p. 135) }\end{array}$ \\
\hline
\end{tabular}

A fala de Amaka reflete sua segurança em ser mulher. Em nenhum momento ela precisa se afirmar como mulher, e também não sente nunca a necessidade de ser protegida ou guiada por um homem. Mesmo sendo uma adolescente, já demonstra que seguirá os passos da mãe e se tornará uma mulher autônoma, com opinião própria. Uma mulher que demonstra por meio de atitudes e do seu discurso que o gênero não deve ser uma forma de distinção. A adolescente valoriza a cultura local, as tradições e músicas Igbo, e questiona a imposição de valores eurocêntricos, como nomes e valores católicos.

No segundo romance, Half of a yellow sun, as irmãs gêmeas Olanna e Kainene são as protagonistas. Filhas de um rico empresário nigeriano, são duas mulheres que não se adéquam ao meio e ao que é esperado delas. Muitas são as falas e as atitudes ousadas de ambas ao longo da história.

Olanna é a gêmea mais emocional, que segue seu coração. Apaixonada por um professor universitário, Odenigbo, deixa a vida confortável em Lagos e se muda para a 
cidade de Nsukka, onde passa a viver com ele e a trabalhar como professora. Ela enfrenta as críticas da sua família, que acredita que ela poderia viver uma vida de luxo ao lado de um homem influente e rico, e da mãe de Odenigbo, por viverem maritalmente sem assumirem o compromisso do matrimônio (por decisão da própria Olanna), e por não poder gerar um filho.

Ela é uma mulher segura e confiante, que se afirma, se impõe, em diversas ocasiões. Ao confrontar Odenigbo quando descobre sua traição. E ao decidir perdoá-lo e reatar o relacionamento. Ao acolher a filha de Odenigbo com a empregada de sua mãe e criá-la como sua própria filha. Ao abandonar a casa onde morava para viver na comunidade que criaria a nação Biafra.

Olanna segue o conselho de sua tia Ifeka: "“Você nunca deve se comportar como se a sua vida pertencesse a um homem. Ouviu bem?', disse tia Ifeka. 'A sua vida pertence a você e só a você, soso gi."” (p. 186). Na Tabela 3, estão alguns trechos em que sua atitude assertiva pode ser vista.

Tabela 3: Exemplos de discursos de Olanna

\begin{tabular}{|c|c|}
\hline Half of a yellow sun & Meio sol amarelo (tradução de Beth Vieira) \\
\hline $\begin{array}{l}\text { She was used to this, being grabbed by men } \\
\text { who walked around in a cloud of cologne- } \\
\text { drenched entitlement, with the presumption } \\
\text { that, because they were powerful and found } \\
\text { her beautiful, they belonged together. She } \\
\text { pushed him back, finally, and felt vaguely } \\
\text { sickened at how her hands sank into his soft } \\
\text { chest. "Stop it, Chief." (p. 32) }\end{array}$ & $\begin{array}{l}\text { Estava acostumada com isso, com ser } \\
\text { agarrada por homens embebidos em nuvens de } \\
\text { direitos, recendendo a colônia, que } \\
\text { presumiam, por serem poderosos e acharem-na } \\
\text { bonita, que eles se pertenciam. Por fim, } \\
\text { empurrou-o e sentiu uma náusea vaga ao } \\
\text { perceber que suas mãos haviam afundado } \\
\text { naquele peito mole. "Pare com isso, chefe." (p. } \\
\text { 31) }\end{array}$ \\
\hline $\begin{array}{l}\text { "I don't want to work in Lagos. I want to work } \\
\text { in the university, and I want to live with } \\
\text { him."(p. 33) }\end{array}$ & $\begin{array}{l}\text { "Eu não quero trabalhar em Lagos. Quero } \\
\text { trabalhar na universidade e quero morar com } \\
\text { ele." (p. 33) }\end{array}$ \\
\hline $\begin{array}{l}\text { "Our relationship is the most important thing } \\
\text { to me, nkem," he said quietly. "We have to } \\
\text { make the right decision for us." }\end{array}$ & $\begin{array}{l}\text { "Nossa relação é o mais importante, para } \\
\text { mim, nkem", disse ele, baixinho. "Temos de } \\
\text { tomar a decisão correta para nós." }\end{array}$ \\
\hline $\begin{array}{l}\text { "You were not thinking about us when you got } \\
\text { her pregnant", Olanna said. (p. 175) }\end{array}$ & $\begin{array}{l}\text { "Você não estava pensando em nós quando } \\
\text { engravidou a moça", disse Olanna. (p. 206) }\end{array}$ \\
\hline
\end{tabular}

Kainene é uma mulher altiva, que não se importa em ser o centro das atenções; transborda confiança e tem uma atitude sarcástica e crítica que não evita nem oculta. Administra as empresas e a riqueza do pai, trata de assuntos políticos, negocia de igual para igual com homens poderosos. O elogio machista de seu pai, ao dizer que "Kainene não é só como um filho, ela é como dois filhos homens" (p. 30), é desprezado por ela. 
A opinião dos outros, sobretudo a masculina, para ela não importa. Suas escolhas, seu estilo de vida, o hábito de fumar, o homem com quem se relaciona (um inglês branco), nada afeta Kainene (Tabela 4).

\section{Tabela 4: Exemplos de discursos de Kainene}

\begin{tabular}{|l|l|}
\hline \multicolumn{1}{|c|}{ Half of a yellow sun } & Meio sol amarelo (tradução de Beth Vieira) \\
\hline $\begin{array}{l}\text { Kainene looked Chief Okonji right in the eyes, } \\
\text { with that stare that was so expressionless, so } \\
\text { blank, that it was almost hostile. "What about } \\
\text { me indeed?" She raised her eyebrows. "I too } \\
\text { will be putting my newly acquired degree to } \\
\text { good use. I'm moving to Port Harcourt to } \\
\text { que era quase um ato de hostilidade. "E quanto } \\
\text { manage Daddy's businesses there."(p. 31) } \\
\text { a mim, é o que eu me pergunto." Ergueu as } \\
\text { recém-adquirido diploma em uso. Vou me } \\
\text { mudar para Port Harcourt para administrar os } \\
\text { negócios de papai por lá." (p. 30) }\end{array}$ \\
$\begin{array}{l}\text { "The benefit of being the ugly daughter is that } \\
\text { nobody uses you as sex bait." (p. 33) }\end{array}$ & $\begin{array}{l}\text { "O bom de ser a filha feia é que ninguém usa a } \\
\text { gente como isca sexual." (p. 33) }\end{array}$ \\
\hline $\begin{array}{l}\text { "How's Nsukka? How's your revolutionary } \\
\text { lover?" (p. 75) }\end{array}$ & $\begin{array}{l}\text { "Como vai Nsukka? E o seu amante } \\
\text { revolucionário?" (p. 87) }\end{array}$ \\
\hline $\begin{array}{l}\text { "Isn't it against the tenets of socialism, } \\
\text { though, impregnating people of the lower } \\
\text { classes?" Kainene asked.(p. 172) }\end{array}$ & $\begin{array}{l}\text { "Mas não é contra os princípios do socialismo } \\
\text { engravidar pessoas das classes inferiores?", } \\
\text { perguntou Kainene. (p. 203) }\end{array}$ \\
\hline
\end{tabular}

O mais recente romance de Chimamanda, Americanah, narra a história de Ifemelu, uma nigeriana que deixa seu país e vai viver nos Estados Unidos. O livro tem muito das experiências de Chimamanda nos Estados Unidos: assim como Ifemelu, a escritora trabalhou como babá, passou por conflitos culturais e estranhamento da generalização como "africana" e experimentou toda a situação racial daquele país.

A personagem questiona tudo: os padrões de beleza da sociedade norteamericana, tão diferentes dos da Nigéria - onde modelos e capas de revistas têm o tom de pele e os cabelos semelhantes aos das mulheres locais, onde se pode comprar maquiagem e facilmente conseguir um cabeleireiro que tenha costume de lidar com cabelos de mulheres negras; o tratamento dado a imigrantes nos Estados Unidos e na Inglaterra; e a forma como esses mesmos imigrantes são tratados ao retornarem ao seu país de origem, com um comportamento e uma visão de mundo mudados pela experiência.

A própria Chimamanda se tornou uma "Americanah", que é como os nigerianos se referem àquelas pessoas que voltam da América: geralmente em uma condição financeira superior, com status, sotaque alterado pela interferência do estrangeiro, opinião crítica sobre hábitos culturais que são considerados normais pela maioria, e sofreu e sofre críticas dos nigerianos que reprovam sua fama internacional, seu sotaque 
com nuances americanas e o fato de morar nos Estados Unidos. Ainda assim, não se trata de um livro autobiográfico. As experiências da escritora são apenas o ponto de partida para o romance.

Ifemelu é a personagem feminista por excelência. Sua atitude decidida, sua independência, sua recusa a se recolher e se submeter a um homem ou a uma regra social e, até mesmo, seus relacionamentos amorosos - nos quais é ela quem decide se vai ou não se entregar, se vai se envolver apenas fisicamente ou também sentimentalmente com o homem e continuar a relação -, estão em sintonia com cada um dos aspectos dos discursos da escritora, sobretudo com Sejamos todos feministas. Ela registra suas reflexões em um blog, que atrai milhares de seguidoras, principalmente mulheres negras. Nos textos da personagem, é possível ouvir sua voz: ela protesta, discorda e, por vezes, faz uso do humor e do sarcasmo para fazer sua voz ser ouvida. Critica a invisibilidade da mulher negra dentro da sociedade e da cultura norteamericana, os padrões de beleza impostos e preconceitos quanto aos cabelos de mulheres negras e, sobretudo, o racismo. Vejamos alguns trechos do blog Small Redemptions of Lagos (Tabela 5):

Tabela 5: Trechos do blog da personagem Ifemelu

\begin{tabular}{|c|c|}
\hline Americanah & Americanah (tradução de Júlia Romeu) \\
\hline $\begin{array}{l}\text { You see, in American pop culture, beautiful } \\
\text { dark women are invisible. (The other group } \\
\text { just as invisible is Asian men. But at least they } \\
\text { get to be super smart.) In movies, dark black } \\
\text { women get to be the fat nice mammy or the } \\
\text { strong, sassy, sometimes scary sidekick } \\
\text { standing by supportively. They get to dish out } \\
\text { wisdom and attitude while the white woman } \\
\text { finds love. But they never get to be the hot } \\
\text { woman, beautiful and desired and all. (p.158) }\end{array}$ & $\begin{array}{l}\text { Na cultura pop americana, as mulheres bonitas } \\
\text { de pele escuras são invisíveis. (Outro grupo } \\
\text { que é tão invisível quanto é o de homens } \\
\text { asiáticos. Mas, pelo menos, eles são } \\
\text { considerados superinteligentes.) Nos filmes, as } \\
\text { mulheres de pele escura fazem o papel da } \\
\text { empregada gorda e maternal, ou da amiga da } \\
\text { protagonista, que é forte, desbocada e às vezes } \\
\text { assustadora, e que está sempre ali pra dar um } \\
\text { apoio. Elas falam coisas sábias e têm atitude, } \\
\text { enquanto a mulher branca encontra um grande } \\
\text { amor. Mas elas nunca podem fazer o papel da } \\
\text { mulher gostosa, linda e desejada por todos. (p. } \\
\text { 158) }\end{array}$ \\
\hline $\begin{array}{l}\text { I have natural kinky hair. Worn in cornrows, } \\
\text { Afros, braids. No, it's not political. No, I am } \\
\text { not an artist or poet or singer. Not an earth } \\
\text { mother either. I just don't want relaxers in my } \\
\text { hair - there are enough sources of cancer in } \\
\text { my life as it is. (p. 217) }\end{array}$ & $\begin{array}{l}\text { Eu tenho cabelo crespo natural. Que uso em } \\
\text { afros, tranças, tranças de raiz. Não, não é uma } \\
\text { coisa política. Não, eu não sou artista plástica, } \\
\text { poeta ou cantora. Também não sou natureba. } \\
\text { Só não quero relaxar o cabelo - já estou em } \\
\text { contato com muitas outras substâncias } \\
\text { cancerígenas no meu cotidiano. (p. } 217 \text { ) }\end{array}$ \\
\hline $\begin{array}{l}\text { Racism should never have happened and so } \\
\text { you don't get a cookie for reducing it. (p. 222) }\end{array}$ & $\begin{array}{l}\text { O racismo nunca deveria ter acontecido, então } \\
\text { você não ganha um doce por ele ter diminuído. } \\
\text { (p. 222) }\end{array}$ \\
\hline Don't say “Oh, it's not really ra & Não diga: “Ah, na verdade não é uma questão \\
\hline
\end{tabular}


Oh, it's not race, it's gender. Oh, it's not race, it's the cookie monster." You see, American Blacks actually don't WANT it to be race. They would rather not have racist shit happen. So maybe when they say something is about race, it's maybe because it actually is? (p. 237)

If you don't understand, ask questions. If you're uncomfortable about asking questions, say you are uncomfortable about asking questions and then ask anyway. It's easy to tell when a question is coming from a good place. (p. 238) de raça, mas de classe. Ah, não é uma questão de raça, mas de gênero." Ah, não é uma questão de raça, é o bicho-papão. Entenda, os Negros Americanos na verdade não querem que seja uma questão de raça. Para eles, seria melhor se merdas racistas não acontecessem. Portanto, quando dizem que algo é uma questão de raça, talvez seja porque é mesmo, não? (p. 237)

Se você não entende, faça perguntas. Se tem vergonha de fazer perguntas, diga que tem vergonha de fazer perguntas e faça assim mesmo. É fácil perceber quando uma pergunta está sendo feita de coração. (p. 238)

\section{$1.3 \mathrm{O}$ florescer - o hibisco e a Nigéria}

Sim, eu acredito que é impossível escrever qualquer coisa na África sem algum tipo de engajamento, sem algum tipo de mensagem, algum tipo de protesto. Mesmo aqueles primeiros romances que pareciam recriações suaves do passado - o que eles estavam dizendo, de fato, é que nós tínhamos um passado. Isso era um protesto, porque havia pessoas que pensavam que nós não tínhamos um passado. O que nós estávamos fazendo era dizer, educadamente, que nós tínhamos - aqui está. Então, o engajamento não é uma coisa nova. O engajamento passa por todo o nosso trabalho. ${ }^{24}$ (Achebe, apud NUNES, 2008, p. 6).

A narradora de Hibisco roxo, Kambili, e seu irmão Jaja só passam a enxergar outra possibilidade de vida - sem violência, sem o peso da imposição de comportamento do pai e da Igreja Católica, sem medo - quando convivem com a família de tia Ifeoma em Nsukka. É após essa experiência de liberdade de pensamento, de fala e de voz, que "o mundo começou a se despedaçar". ${ }^{25}$

\footnotetext{
24 "Yes, I believe it's impossible to write anything in Africa without some kind of commitment, some kind of message, some kind of protest. Even those early novels that look like very gentle recreations of the past - what they were saying, in effect, was that we had a past. That was protest, because there were people who thought we didn't have a past. What we were doing was to say politely that we did - here it is. So commitment is nothing new. Commitment runs right through our work."

${ }^{25}$ Disponível em: <https://www.poetryfoundation.org/poems-and-poets/poems/detail/43290>). "Things started to fall apart at home" é a primeira frase de Purple hibiscus. Traduzida em Hibisco roxo como "Tudo desmoronou", é uma referência ao título do primeiro romance de Chinua Achebe (1958), traduzido no Brasil como $O$ mundo se despedaça, e em Portugal como Quando tudo se desmorona. $\mathrm{O}$ título de Achebe é uma referência a um verso do poema "The Second Coming", do poeta irlandês William Butler Yeats, publicado em 1920. ["Things fall apart; the centre cannot hold / Mere anarchy is loosed upon the world"].
} 
Na casa de Ifeoma, cercada por plantas, os irmãos descobrem uma flor que não existe nos jardins da sua mansão, tão bem cuidados, cultivados por empregados e repletos de flores podadas milimetricamente: o hibisco roxo. Ela chama a atenção por ser exótica, e é tão bela e causa tanta fascinação que, ao retornar para casa, Jaja leva consigo uma muda e planta-a no seu jardim. Na Tabela 6, apresento trechos do romance em que os personagens se referem aos "hibiscos roxos".

\section{Tabela 6: Referências aos hibiscos roxos}

\begin{tabular}{|c|c|}
\hline Purple hibiscus & Hibisco roxo (tradução de Júlia Romeu) \\
\hline $\begin{array}{l}\text { Closer to the house, vibrant bushes of hibiscus } \\
\text { reached out and touched one another as if they } \\
\text { were exchanging their petals. The purple } \\
\text { plants had started to push out sleepy buds, but } \\
\text { most of the flowers were still on the red ones. } \\
\text { (p. 8) }\end{array}$ & $\begin{array}{l}\text { Mais perto da casa, os coloridos arbustos de } \\
\text { hibiscos se esticavam e tocavam uns aos } \\
\text { outros, como se estivessem trocando pétalas. } \\
\text { Os arbustos de hibiscos roxos começavam a } \\
\text { florescer lentamente, porém a maioria das } \\
\text { flores ainda era vermelha. (p. } 8 \text { ) }\end{array}$ \\
\hline $\begin{array}{l}\text { Jaja's defiance seemed to me now like Aunty } \\
\text { Ifeoma's experimental purple hibiscus: rare, } \\
\text { fragrant with the undertones of freedom, a } \\
\text { different kind of freedom from the one the } \\
\text { crowds waving green leaves chanted at } \\
\text { Government Square after the coup. A freedom } \\
\text { to be, to do. (p. 13) }\end{array}$ & $\begin{array}{l}\text { A rebeldia de Jaja era como os hibiscos roxos } \\
\text { experimentais de tia Ifeoma: rara, com o } \\
\text { cheiro suave da liberdade, uma liberdade } \\
\text { diferente daquela que a multidão, brandindo } \\
\text { folhas verdes, pediu na Government Square } \\
\text { após o golpe. Liberdade para ser, para fazer. } \\
\text { (p. 11) }\end{array}$ \\
\hline $\begin{array}{l}\text { But my memories did not start at Nsukka. } \\
\text { They started before, when all the hibiscuses in } \\
\text { our front yard were a startling red. (p.13) }\end{array}$ & $\begin{array}{l}\text { Mas minhas lembranças não começavam em } \\
\text { Nsukka. Começavam antes, quando todos os } \\
\text { hibiscos do nosso jardim da frente ainda eram } \\
\text { de um vermelho chocante. (p.11) }\end{array}$ \\
\hline $\begin{array}{l}\text { In front was a circular burst of bright colors - } \\
\text { a garden - fenced around with barbed wire. } \\
\text { Roses and hibiscuses and lilies and ixora and } \\
\text { croton grew side by side like a handpainted } \\
\text { wreath. (p. 58) }\end{array}$ & $\begin{array}{l}\text { Na frente dele, havia um círculo de cores } \\
\text { vibrantes - um jardim - com uma cerca de } \\
\text { arame farpado em volta. Rosas, hibiscos, } \\
\text { lírios, ixoras e crótons cresciam lado a lado } \\
\text { como numa guirlanda pintada à mão. (p. 57) }\end{array}$ \\
\hline $\begin{array}{l}\text { "'That's a hibiscus, isn't it, Aunty?' Jaja } \\
\text { asked, staring at a plant close to the barbed } \\
\text { wire fencing. 'I didn't know there were purple } \\
\text { hibiscuses.' } \\
\text { Aunty Ifeoma laughed and touched the flower, } \\
\text { colored a deep shade of purple that was almost } \\
\text { blue. 'Everybody has that reaction the first } \\
\text { time. My good friend Phillipa is a lecturer in } \\
\text { botany. She did a lot of experimental work } \\
\text { while she was here."' (p. 65) }\end{array}$ & $\begin{array}{l}\text { - Isso é um hibisco, não é, tia? - perguntou } \\
\text { Jaja, olhando uma planta que havia perto da } \\
\text { cerca de arame farpado. } \\
\text { - Não sabia que existiam hibiscos roxos. } \\
\text { Tia Ifeoma riu e tocou a flor, que era de um } \\
\text { tom púrpura tão fechado que chegava quase a } \\
\text { ser azul. } \\
\text { - Todo mundo tem essa reação quando vê } \\
\text { essas flores pela primeira vez. Minha amiga } \\
\text { Phillipa é professora de botânica. Ela fez } \\
\text { alguns experimentos na época em que morava } \\
\text { aqui. (p. 65) }\end{array}$ \\
\hline $\begin{array}{l}\text { It was wrapped in black cellophane paper, as } \\
\text { well, and he had lodged it in the refrigerator, } \\
\text { beneath bottles of Fanta. When he saw my } \\
\text { puzzled look, he said they weren't just sticks; } \\
\text { they were stalks of purple hibiscus. He would } \\
\text { give them to the gardener. (p. 97) }\end{array}$ & $\begin{array}{l}\text { A coisa também estava embrulhada em papel } \\
\text { celofane preto, e Jaja a colocara dentro da } \\
\text { geladeira, atrás de algumas garrafas de Fanta. } \\
\text { Quando viu meu olhar de interrogação, } \\
\text { explicou que aqueles não eram apenas galhos; } \\
\text { eram galhos de hibiscos roxos. (p. 97) }\end{array}$ \\
\hline Jaja's eyes shone as he talked about the & Os olhos de Jaja brilharam quando ele falou \\
\hline
\end{tabular}




\begin{tabular}{|c|c|}
\hline $\begin{array}{l}\text { hibiscuses, as he held them out so I could } \\
\text { touch the cold, moist sticks. He had told Papa } \\
\text { about them, yet he quickly put them back into } \\
\text { the fridge when we heard Papa coming. (p. 97) }\end{array}$ & $\begin{array}{l}\text { dos hibiscos, quando os tirou da geladeira } \\
\text { para que eu pudesse tocar os galhos frios e } \\
\text { úmidos. Ele contara a Papa sobre eles, mas } \\
\text { mesmo assim os colocou rapidamente de volta } \\
\text { na geladeira quando o ouviu se aproximando. } \\
\text { (p. 97) }\end{array}$ \\
\hline $\begin{array}{l}\text { "See, the purple hibiscuses are about to } \\
\text { bloom," Jaja said, as we got out of the car. He } \\
\text { was pointing, although I did not need him to. I } \\
\text { could see the sleepy, oval-shape buds in the } \\
\text { front yard as they swayed in the evening } \\
\text { breeze. (p. 122) }\end{array}$ & $\begin{array}{l}\text { - Viu, os hibiscos roxos estão prestes a } \\
\text { florescer - disse Jaja quando saímos do carro. } \\
\text { Ele estava apontando, mas eu não precisava } \\
\text { que fizesse isso. Já tinha visto os botões ovais } \\
\text { e sonolentos no jardim, balançando ao sabor } \\
\text { da brisa do fim da tarde. (p. 127) }\end{array}$ \\
\hline $\begin{array}{l}\text { "We'll plant new orange trees in Abba when } \\
\text { we come back, and Jaja will plant purple } \\
\text { hibiscus, too, and I'll plant ixora so we can } \\
\text { suck the juices of the flowers." (p. 146) }\end{array}$ & $\begin{array}{l}\text { - Vamos plantar laranjeiras novas em Abba } \\
\text { quando voltarmos, e Jaja vai plantar hibiscos } \\
\text { roxos também, e eu vou plantar ixoras para } \\
\text { podermos sugar o suco das flores. (p. 149) }\end{array}$ \\
\hline
\end{tabular}

Na mansão da família Achike, há hibiscos vermelhos que se proliferam e estão sempre florescendo. Porém, hibiscos vermelhos são comuns, não exigem esforço para serem cultivados e voltam facilmente a brotar, quando arrancados. Em Purple hibiscus, as flores vermelhas sempre são mencionadas em situações de opressão: próximas a agentes federais do governo em busca de suborno, na decoração do altar da igreja, e na presença de Eugene. Já o hibisco roxo é uma flor híbrida, resultado de um experimento, e é relacionado à ideia de novidade, de liberdade, de mudança.

A mudança que acontece com Kambili e Jaja, descobrindo sua própria identidade e conhecendo a si mesmos após tantos anos de opressão, também é a história da Nigéria. O florescer do hibisco roxo, o resgate de sua própria voz e o desenvolvimento de uma resistência à opressão podem ser lidos como a história do país que, após a independência do Reino Unido, em 1960, passa a ter a oportunidade de seguir por um caminho diferente tanto daquele traçado pelo colonizador, como da tradição dos antepassados. Mas, ao mesmo tempo, é uma independência delicada, ainda jovem e muito tênue, pois se trata de um momento de conflito, de transculturação, para o surgimento de uma terceira possibilidade cultural.

As famílias de Eugene e Ifeoma representam bem o que Chinua Achebe, precursor da literatura nigeriana, denomina de crossroads of cultures. Segundo Pereira (2012), essa "encruzilhada de culturas" a que Achebe se refere é um ponto de escolhas, em que não há só o encontro do antes e do depois da independência, mas a necessidade de optar por qual caminho seguir: 
A coabitação de duas culturas diferentes, com suas respectivas religiões, costumes e línguas é para ele como um cruzamento na estrada - uma imagem metafórica para representar a convivência "porta-a-porta" de dois mundos tão diferentes (PEREIRA, 2012, p. 28).

Em uma entrevista, a própria Chimamanda explica seu desejo de escrever sobre o colonialismo:

Eu queria escrever sobre o colonialismo, que é algo que eu acho que todo escritor africano faz, mesmo sem ter a intenção. A forma como somos é, em grande parte, resultado do colonialismo - o fato de eu pensar em inglês, por exemplo $^{26}$ (Chimamanda apud GARNER, 2005, p. 149).

Ela reconhece a influência de Chinua Achebe, que, segundo ela, foi o responsável pela descoberta da possibilidade de escrever uma literatura que se passa na Nigéria, com personagens e paisagens com as quais um nigeriano e qualquer africano poderiam se identificar.

Nunes (2005, p. 19) descreve a experiência de Achebe que, apaixonado por literatura e pela oralidade das histórias dos Igbos, "percebeu que nas aventuras que lia não sabia identificar que partido tomar: aquele do 'bom homem branco' ou do suposto 'negro selvagem'". Assim, mesmo sendo africano, acabava por ficar ao lado do homem branco, detentor das qualidades e do ideal de força e beleza, enquanto o negro africano era visto como inferior:

$\mathrm{O}$ autor afirma que desse contato perverso originaram suas reflexões sobre o papel da arte e da literatura para o público africano. Percebia que os currículos escolares de então não contemplavam as histórias africanas. Nesta época impressiona-se com um provérbio igbo que dizia: "até que os leões tenham seus próprios historiadores, a história da caça sempre glorificará o caçador" (NUNES, 2005, p. 20).

E foi a partir de então que Achebe abraçou a missão de devolver aos nigerianos suas histórias, resgatar sua dignidade e também mostrar ao mundo uma outra visão de África.

Segundo ele, no processo de colonização, o povo colonizado perde sua dignidade, uma parte de sua identidade, bem como o orgulho por sua cultura. Os valores e costumes desaparecem diante das referências trazidas pelo colonizador. Para Achebe, "o escritor é como um educador, que deve dar a seu público os meios para olhar sua cultura com respeito" (PEREIRA, 2012, p. 26).

\footnotetext{
26 "I wanted to write about colonialism, which I think every African writer does without meaning to. The way we are is very much the result of colonialism - the fact that I think in English, for example."
} 
Um dos frutos dessa missão, uma flor que desabrochou lendo a obra de Chinua Achebe (1930-2013), foi Chimamanda. Ela faz parte do que se convencionou chamar de "Escola Achebiana", formada por escritores que, seguindo o caminho aberto por Achebe, produzem literatura sobre a África, para contar a história a partir de outra perspectiva, valorizando a cultura tradicional africana e denunciando a destruição que o colonialismo europeu (inglês, no caso da Nigéria) causou a esses povos.

Ler Achebe me deu permissão para escrever sobre o meu mundo. Ele me transportou a um passado que era ao mesmo tempo familiar e desconhecido, um passado no qual eu imaginava que meu bisavô tivesse vivido. Quando olho para trás, percebo que o que ele fez por mim foi validar minha história, torná-la, de certa forma, digna ${ }^{27}$ (Chimamanda apud GARNER, 2005, [s.p.]).

Em sua palestra The danger of a single story, ${ }^{28}$ Chimamanda fala sobre o perigo por trás da construção de estereótipos, que levam ao apagamento da multiplicidade de versões para um mesmo fato e um mesmo local. Ela narra sua própria experiência com a literatura, quando, ainda criança, era influenciada por livros infantis ingleses e norteamericanos - cujas histórias sempre se passavam em locais com uma natureza diferente da sua, com neve e pinheiros, e cujos personagens tinham hábitos e aparência física também diferentes -, com os quais ela não poderia se identificar, e que ela reproduzia nas primeiras histórias que escreveu. Ela conta que foi por meio de Achebe que descobriu que a história do seu país e do seu próprio continente poderia ser contada, e que poderia haver livros com personagens e histórias como a dela. E assim, sua escrita floresceu:

Porque tudo que eu havia lido eram livros nos quais as personagens eram estrangeiras, eu convenci-me de que os livros, por sua própria natureza, tinham que ter estrangeiros e tinham que ser sobre coisas com as quais eu não podia me identificar.

Bem, as coisas mudaram quando eu descobri os livros africanos. Não havia muitos disponíveis e eles não eram tão fáceis de encontrar quanto os livros estrangeiros, mas devido a escritores como Chinua Achebe e Camara Laye eu passei por uma mudança mental em minha percepção da literatura. Eu percebi que pessoas como eu, meninas com a pele da cor de chocolate, cujos cabelos crespos não poderiam formar rabos de cavalo, também podiam existir na literatura. Eu comecei a escrever sobre coisas que eu reconhecia.

\footnotetext{
27 "Reading Achebe gave me permission to write about my world. He transported me to a past that was both familiar and unfamiliar, a past I imagined my great grandfather lived. Looking back, I realize that what he did for me at the time was validate my history, make it seem worthy in some way."

28 Versão em português oficial do site. Discurso disponível em: <https://www.ted.com/talks/chimamanda_adichie_the_danger_of_a_single_story?language=pt-br >.
} 
Bem, eu amava aqueles livros americanos e britânicos que eu lia. Eles mexiam com a minha imaginação, me abriam novos mundos. Mas a consequência inesperada foi que eu não sabia que pessoas como eu podiam existir na literatura. Então o que a descoberta dos escritores africanos fez por mim foi: salvou-me de ter uma única história sobre o que os livros são (ADICHIE, 2009). ${ }^{29}$

Chimamanda faz parte da terceira geração de escritores da Escola Achebiana, pois ela não viveu o período em que a Nigéria era uma colônia inglesa, o processo de independência do país, nem a guerra civil nigeriana. Nascida em 1977, ela sempre viveu na Nigéria independente, a República da Nigéria. Esse distanciamento temporal dos fatos históricos formadores do país torna o ponto de vista de sua análise e de sua narrativa distinto, transitando entre "o agora" e "o anterior", mantendo o diálogo com seus predecessores e demonstrando as influências das leituras feitas pela escritora. Como afirmam Sousa e Costa (2015):

A complexa e dinâmica organização que constitui o texto literário, além de ser contextualizada historicamente, tem como meta levar o leitor ao universo criado pelo escritor. Desse modo, podem-se perceber as influências das leituras feitas pelo escritor, isto é, a intertextualidade, sua leitura e releitura de mundo (SOUSA; COSTA, 2015, p. 161).

Em seus romances, Chimamanda expõe as consequências dessa colonização e os conflitos culturais (em Purple hibiscus), as feridas abertas pela guerra de Biafra às gerações que não viveram à época do massacre (em Half of a yellow sun) e mostra os conflitos atuais no país e a vida dos nigerianos imigrantes da chamada "diáspora" (em

\section{Americanah).}

Por diversas ocasiões, em textos e entrevistas, Chimamanda faz questão de frisar a importância e a influência de Achebe. Ela diz que esteve nos mesmos eventos em que o autor estava presente em três ocasiões, mas que nunca teve um contato próximo,

\footnotetext{
${ }^{29}$ Disponível em:

<https://www.ted.com/talks/chimamanda_adichie_the_danger_of_a_single_story?language=pt-br $>$.

["Because all I had read were books in which characters were foreign, I had become convinced that books by their very nature had to have foreigners in them and had to be about things with which I could not personally identify. Now, things changed when I discovered African books. There weren't many of them available, and they weren't quite as easy to find as the foreign books.

But because of writers like Chinua Achebe and Camara Laye, I went through a mental shift in my perception of literature. I realized that people like me, girls with skin the color of chocolate, whose kinky hair could not form ponytails, could also exist in literature. I started to write about things I recognized.

Now, I loved those American and British books I read. They stirred my imagination. They opened up new worlds for me. But the unintended consequence was that I did not know that people like me could exist in literature. So what the discovery of African writers did for me was this: It saved me from having a single story of what books are."]
} 
somente diálogos rápidos com aquele que ela chama de "ídolo". ${ }^{30}$ Mesmo assim, recebeu mensagens e comentários elogiosos do autor por meio de sua editora.

Contudo, apesar de sua admiração, Chimamanda faz questão de deixar claro que não quer viver à sombra de Achebe, mas que tem seu próprio projeto literário, sua própria identidade, e que essa comparação com o escritor não pode ser um parâmetro para a avaliação de sua produção. Nunes $(2016$, p. 216) cita a fala da escritora, que se sente, ao mesmo tempo, lisonjeada e cobrada pelas semelhanças com Achebe:

\begin{abstract}
Nosso país pode ter muitos problemas, mas nós ainda tempos uma cultura da qual podemos nos orgulhar. Por isso, eu acho que Achebe foi muito importante para mim. Eu amava seus trabalhos e o que ele fez, e eu volto a lê-lo frequentemente. Quando as pessoas me dizem "você está seguindo Achebe, parece que você é o novo Achebe", me sinto lisonjeada. E, ao mesmo tempo, eu espero que as pessoas não pensem que eu sou Achebe Segunda. Eu quero ser Adichie; seguindo o que Achebe fez, mas fazendo do meu jeito (ADICHIE apud NUNES, 2016, tradução minha). ${ }^{31}$
\end{abstract}

Chimamanda evita a associação excessiva, tanto de sua obra quanto de sua vida à de Achebe. Embora ambos pertençam à etnia Igbo e tenham morado, em períodos diferentes, na mesma casa, no campus da Universidade da Nigéria, em Nsukka coincidência da qual só tomou conhecimento anos depois -, ela não quer ser vista como envolta na "aura" do escritor. A admiração mútua é conhecida. Porém, ela faz questão de reforçar que outros escritores africanos também a influenciaram, como os nigerianos Buchi Emecheta, Flora Nwapa e Christopher Okigbo, o queniano Binyavanga Wainaina e Camara Laye, de Guiné. Em uma ocasião, ao ser arguida sobre a influência de Achebe - que é uma pergunta recorrente em entrevistas -, Chimamanda respondeu com humor e ironia:

Quando você é um escritor da África subsaariana, espera-se que você seja como Chinua Achebe, que é chamado "o pai da literatura africana moderna". Mas, provavelmente, você é comparado a ele porque as pessoas não

\footnotetext{
${ }^{30}$ A escritora narra esses eventos em um artigo publicado em novembro de 2012 , no aniversário de 82 anos de Achebe. Disponível em: <http://www.premiumtimesng.com/arts-entertainment/108378-chinuaachebe-at-82-we-remember-differently-by-chimamanda-ngozi-adichie.html\#amph=1>.

31 "It is my identity, something that I'm deeply proud of. Nigerians as a whole, we really should be keenabout our culture, so if I sell a book written by a Yoruba person that is very insistently Yoruba, I wouldadmire it as long as it is good thing. I think it is about time we started to value who we are. Our countrymay have many problems we still have a culture that we can afford to be proud of. So I think Achebe wasvery important for me. I really loved his works and what he did and I go back to read him constantly. Whenpeople say to me, you are following Achebe, it is like you are the next Achebe. I feel very flattered. And atthe same time, I hope that people don't think that I'm Achebe the Second. I want to be Adichie; following from what Achebe has done, but very much doing my own thing."
} 
conhecem nenhum outro escritor da África. [...] Então, eu sempre me pergunto quem é a mãe da literatura africana. E além disso: por que é que a literatura africana precisa de um pai e de uma mãe ? $^{32}$

32 Entrevista concedida ao site Times of India, em janeiro de 2011. Disponível em: $<$ http://timesofindia.indiatimes.com/city/jaipur/The-humour-and-politics-of-being-

Adichie/articleshow/7356435.cms>. ["Being a sub-Saharan African writer, you're supposed to be like Chinua Achebe, who is called the father of modern African literature. But you're probably compared to him because people don't know any other writers from Africa, she said. Then I always want to know who 'the mother of African literature is'. And also, why does African literature need a father and a mother at all?"] (Acesso em 01 de fevereiro de 2017) 


\section{CAPÍTULO 2: SPEAKING WITH OUR SPIRITS: A VOZ DAS PERSONAGENS}

\subsection{A voz e o silêncio em Purple hibiscus: marcas feministas nas personagens e nos discursos}

Purple hibiscus pode ser classificado como um Bildungsroman ou "romance de formação": ao longo da história, a personagem-narradora Kambili transforma-se, deixando de ser uma menina ingênua e amedrontada para se tornar uma jovem mulher que tem voz e pensamento próprios.

Tunca $^{33}$ (2009) defende que a complexidade do desenvolvimento da personagem e de sua personalidade não pode ser demonstrada simplesmente pela descrição de suas ações. Para ela, o uso que Kambili faz da fala - os tipos de discurso - e a maneira como ela registra suas impressões no discurso narrativo - registro do pensamento - são estratégias linguísticas que fazem parte das características estilísticas da autora e que devem ser igualmente analisadas, para que se alcance uma interpretação mais profunda do livro.

A própria Chimamanda se considera metódica, "obsessiva", quanto à sua escrita e às suas escolhas lexicais. Em uma entrevista ao jornalista Jon Snow, ela fala sobre seu processo criativo e explica por que leva um período considerado longo (cinco anos, no caso de Americanah) para concluir o livro:

Leva tempo. Quer dizer, acho que não sou um daqueles escritores que conseguem, sabe, escrever tudo de uma vez. Para mim, leva tempo. Sabe, eu escrevo devagar. Leva tempo para eu ficar satisfeita com uma frase. E eu reviso, reescrevo várias vezes. Sou um pouco obsessiva. Para mim, a frase é tão importante quanto o personagem. E eu sou muito interessada em meus personagens. Eu quero acreditar neles, quero conhecê-los. Então, eu gasto muito tempo. Eu levo bastante tempo com eles. ${ }^{34}$

É importante que a tradutora (ou o tradutor) tenha consciência de que cada palavra do texto foi escolhida intencionalmente e contém uma carga importante de

\footnotetext{
${ }^{33}$ Daria Tunca é pesquisadora da Universidade de Liège, na Bélgica. Tem diversas pesquisas publicadas sobre a obra de Chimamanda e mantém o site mais completo sobre publicações relacionadas à escritora, constantemente atualizado: 〈http://www.cerep.ulg.ac.be/adichie/index.html>.

${ }^{34}$ Entrevista ao canal britânico Channel 4, publicada em 12 de maio de 2013, grifo meu. Disponível em: <https://www.youtube.com/watch?v=IkwGjjhYZXQ\&list=FL0ohvl2vyreuIqlTV-xXRvA\&index=4>. ["It justtakes a while. I mean, I suppose I am not one of those writers who can, you know, crank them out. It takes a while for me. I need to... You know, I'm a slowwriter. It takes me a while to just be happy with a sentence. And I do lots of revising and rewriting. I'm a bit obsessive about that. For me, the sentence is as important as the character. I'm very interested in my characters. I want to believe them, I want to know them. So, I spend time. I spend quite a bit of time on them.”]
} 
significado. Da mesma forma que o processo criativo, o processo tradutório deve ser minucioso e reflexivo, ciente das estratégias linguísticas adotadas pela autora, para evitar o "achatamento" do significado.

Uma dessas estratégias linguísticas é a escolha da construção sintática do discurso. Segundo Tunca (2009), o uso de discursos do tipo indireto e indireto livre traz um efeito que pode, intencionalmente, gerar uma duplicidade de interpretações. Quando Kambili relata os momentos em que o pai opina sobre assuntos diversos junto à família, discursos e pensamentos registrados de forma indireta e indireta livre chegam às vezes a gerar ambiguidade, pois o leitor pode interpretar a fala como dita pelo pai ou pela filha. Em alguns casos, a ambiguidade formal é solucionada pelo tipo de vocabulário usado, ou posteriormente, quando há uma referência subsequente a quem disse ou pensou. Essa técnica estilística, que mescla intencionalmente os sujeitos, serve para demonstrar o quanto a autoridade do pai está internalizada na personalidade e na visão de mundo da menina.

Um exemplo dessa mescla é o trecho da Tabela 7. Como não há marcas de discurso direto (travessão ou aspas), a frase em destaque pode ser interpretada, sintaticamente, como a continuação da fala do pai, ou o pensamento de Kambili sobre o golpe militar levado a cabo por Ibrahim Babangida, em 1985.

Tabela 7: Mescla de sujeitos do discurso

\begin{tabular}{|l|l|}
\hline \multicolumn{1}{|c|}{ Purple hibiscus } & \multicolumn{1}{c|}{ Hibisco roxo } \\
\hline $\begin{array}{l}\text { Coups begat coups, he said, telling us about } \\
\text { the bloody coups of the sixties, which ended }\end{array}$ & $\begin{array}{l}\text { Golpes levavam a mais golpes, disse Papa, } \\
\text { contando-nos sobre os golpes sangrentos dos } \\
\text { up in civilwar just after he left Nigeria to } \\
\text { anos 1960, que acabaram se transformando em } \\
\text { study in England. A coup always began a } \\
\text { vicious cycle. Military men would always } \\
\text { overthrow one another, because they could, } \\
\text { because they were all power drunk. (p. 15) }\end{array}$ \\
$\begin{array}{l}\text { Nigéria para ir estudar na Inglaterra. Um golpe } \\
\text { sempre iniciava um ciclo vicioso. Militares } \\
\text { sempre derrubariam uns aos outros } \\
\text { simplesmente porque tinham como fazer } \\
\text { isso e porque todos ficavam embriagados } \\
\text { pelo poder. (p. 14) }\end{array}$ \\
\hline
\end{tabular}

Em todo o romance, o pensamento de Kambili, sua expressão pessoal dos fatos, serve como filtro para o que o leitor enxerga. Todos os acontecimentos são retratados pelas lentes da adolescente, o que significa que nem sempre são a expressão dos fatos. A maneira como a filha interpreta a postura de Beatrice, sua mãe, quanto à violência do pai e a sua apatia, é um exemplo dessa interpretação equivocada. A impressão que a 
adolescente tem, de que Beatrice é uma mulher resignada, é de uma menina ainda ingênua (Tabela 8).

Tabela 8: Descrição da postura resignada de Beatrice

\begin{tabular}{|l|l|}
\hline \multicolumn{1}{|c|}{ Purple hibiscus } & \multicolumn{1}{c|}{ Hibisco roxo } \\
\hline $\begin{array}{l}\text { It was not proper to let an older person do } \\
\text { your chores, but Mama did not mind; there } \\
\text { was so much that she did not mind. (p. 13) }\end{array}$ & $\begin{array}{l}\text { Não era certo permitir que uma pessoa mais } \\
\text { velha fizesse suas tarefas, mas Mama não se } \\
\text { nanomodava; havia muita coisa com que ela } \\
\text { nancomodava. (p. 12) }\end{array}$ \\
\hline
\end{tabular}

Essa proposta de análise de aspectos linguísticos e características formais pode ser aplicada também para a apreensão das características feministas do texto. A fim de dar escopo à classificação de Purple hibiscus como um romance feminista - para além da temática tratada e da ideologia defendida por sua autora -, decidi fazer o levantamento das marcas linguísticas desse feminismo - visíveis no léxico, na sintaxe e na semântica - que revelam as escolhas da escritora.

O levantamento e a análise desses aspectos intertextuais, da forma aqui apresentada, são uma contribuição da Análise do Discurso para os Estudos da Tradução. Minha proposta de destacar itens que remetem à oposição entre opressão e liberdade dentro do texto de partida e na tradução busca considerar a linguagem dentro dos jogos de poder, na formação discursiva. Como Campos (2008) explica:

\begin{abstract}
De forma resumida, podemos dizer que a Análise do Discurso (AD) defende ser o discurso um efeito de sentidos entre sujeitos constituídos no jogo sóciohistórico e político ideológico do dizer. Desse modo, a AD interessa particularmente ao campo dos Estudos da Tradução porque traz para a reflexão sobre o funcionamento da linguagem as questões das relações sociais, bem como as de poder sob um viés discursivo. Os sentidos são vistos como tendo relação com o confronto de forças presente na sociedade, em sua dimensão ideológica, não sendo a linguagem tomada pela $\mathrm{AD}$ como um mero instrumento de comunicação de significações. Esse é um dos (muitos) pontos em que as duas áreas se encontram (CAMPOS, 2008, p. 50).
\end{abstract}

Foram levantados termos recorrentes no discurso da narradora-personagem e nas descrições que faz ao longo da narrativa, e também nas falas das demais personagens que fazem referência à voz e ao silêncio, como metáforas do processo de conquista da liberdade. Em seguida, esses termos foram listados e comparados com a tradução feita por Júlia Romeu, em Hibisco roxo, para análise das estratégias tradutórias.

Cabe ressaltar que, para esta análise, não foram selecionadas apenas falas de mulheres, uma vez que, na história, Jaja, irmão de Kambili, é igualmente submetido aos 
maus-tratos e abusos do pai, e sofre a repressão, a violência e o silenciamento. Conforme afirma Bryce (2008, p. 12), a "díade irmã-irmão", ao incluir ambos os gêneros - em vez de privilegiar a feminilidade ou uma consciência individual -, amplia o escopo da subjetividade, de um indivíduo para uma coletividade. Juntos, irmã e irmão compartem mutuamente o que intimamente cada um sofre, e a sobrevivência de um está ligada à sobrevivência do outro.

A cumplicidade entre irmãos, a solidariedade, a empatia entre homens e mulheres e a luta conjunta contra a opressão e pela igualdade são características da postura feminista de Chimamanda que também podem ser inferidas desse contexto.

Para demonstrar mais facilmente como o Bildungsroman vai se desenrolando em uma sequência de conquistas e mudanças, apresento os termos selecionados na ordem cronológica em que se desenvolvem, e não na ordem em que são apresentados no livro. Purple hibiscus tem quatro partes, assim apresentadas: Palm Sunday - Before Palm Sunday - After Palm Sunday - The Present. Em cada parte, selecionei trechos em que termos relacionados à voz e ao silêncio, e também ao olhar, como forma de comunicação (ou fuga dela), revelam como a transformação ocorreu e a liberdade foi conquistada - como os personagens deixaram de falar somente através do espírito e adquiriram uma voz audível - desde o período antes do Domingo de Ramos até o presente.

Classifiquei esses termos em duas categorias, de acordo com o campo lexical: campo lexical do olhar e campo lexical do falar, e destaquei-os em inglês. Também destaquei a forma como foram traduzidos em Hibisco roxo.

No campo lexical do olhar, estão palavras ligadas ao sentido da visão: eye, face, look at, look down, look up, look away, stare, watch, glance, glare, observe, focus, bore into. No campo lexical do falar, estão aquelas relacionadas à expressão verbal: mouth, lip, tongue, word, ask, say, tell, speak, talk, whisper, stutter, mumble, silence, cough, smile, laugh.

Primeiramente, realizei a análise quantitativa desses termos e suas traduções para o português. Para isso, fiz uso do programa AntConc versão 3.2.1, desenvolvido por Laurence Anthony, da Universidade de Waseda, no Japão. Trata-se de uma ferramenta computacional utilizada na linguística de corpus, com diversas funcionalidades, tais como: concordância, lista de ocorrências de palavras, expressões e frases, palavras-chave e frequência de uso. 
O levantamento da frequência das palavras do campo lexical do falar (e suas variantes de número ou tempo verbal, quando foi o caso) é apresentado na Tabela 9. Nos casos em que elas são traduzidas de mais de uma maneira, a tradução aparece na ordem decrescente de frequência no texto. É fácil perceber que, à exceção de talk e speak, cada termo tem um correspondente distinto que, em português, também tem distinções semânticas semelhantes. Isso significa que não há conflitos tradutórios para esses termos.

Tabela 9: Frequência de palavras do campo lexical do falar

\begin{tabular}{|l|l|l|}
\hline \multicolumn{1}{|c|}{ Termo } & $\begin{array}{c}\text { Frequência em } \\
\text { Purple hibiscus }\end{array}$ & \multicolumn{1}{c|}{ Tradução em Hibisco roxo } \\
\hline say & 1029 & dizer \\
\hline ask & 335 & perguntar, pedir \\
\hline tell & 211 & contar \\
\hline talk & 110 & falar, conversar \\
\hline speak & 98 & falar \\
\hline lip & 53 & lábios, lábio \\
\hline mouth & 50 & boca \\
\hline silence & 29 & silêncio \\
\hline whisper & 27 & sussurro, sussurrar \\
\hline tongue & 16 & língua \\
\hline stutter & 10 & gaguejar \\
\hline mumble & 4 & murmurar \\
\hline
\end{tabular}

A estatística de frequência das palavras do campo lexical do olhar (e suas variantes de número ou tempo verbal, quando foi o caso) é apresentada na Tabela 10. $\mathrm{Na}$ coluna da direita, foram descritas as várias traduções empregadas, na ordem decrescente de frequência em que aparecem no texto.

Tabela 10: Frequência de palavras do campo lexical do olhar em Purple hibiscus

\begin{tabular}{|l|l|l|}
\hline \multicolumn{1}{|c|}{ Termo } & $\begin{array}{c}\text { Frequência em } \\
\text { Purple hibiscus }\end{array}$ & \multicolumn{1}{c|}{ Tradução em Hibisco roxo } \\
\hline eyes/eye & 190 & olho, olhos \\
\hline watch & 124 & observar, olhar, ver, examinar \\
\hline look at & 96 & olhar \\
\hline stare & 58 & encarar, olhar \\
\hline look away & 27 & desviar o olhar \\
\hline focus & 14 & fixar o olhar, olhar \\
\hline glance & 6 & olhar, dar uma olhada rápida \\
\hline observe & 4 & observar, olhar \\
\hline glare & 3 & lançar um olhar furioso, olhar furiosamente \\
\hline
\end{tabular}


Após analisar os termos do campo lexical do olhar em Purple hibiscus, levantei também as estatísticas de frequência de palavras relacionadas a esse campo em Hibisco roxo, incluindo verbos e suas conjugações (Tabela 11).

Tabela 11: Frequência de palavras do campo lexical do olhar em Hibisco roxo

\begin{tabular}{|l|c|}
\hline \multicolumn{1}{|c|}{ Termo } & Frequência em Hibisco roxo \\
\hline olho (substantivo) /olhos & 190 \\
\hline ver & 191 \\
\hline olhar (verbo) & 250 \\
\hline olhar (substantivo) & 45 \\
\hline observar & 81 \\
\hline encarar & 20 \\
\hline
\end{tabular}

No comparativo das palavras pertencentes ao campo lexical do olhar, percebe-se que a variedade de verbos em inglês é bem maior que em português. É importante destacar que, mesmo pertencendo ao mesmo campo lexical, os verbos na língua inglesa não são sinônimos, mas possuem diferenças semânticas, havendo uma modulação para expressar ações relacionadas à visão.

Em português, o verbo "olhar", por exemplo, foi usado para traduzir oito verbos diferentes do inglês. É claro que essa generalização de uso causa "achatamentos" no significado original na tradução, cabendo à tradutora (ou ao tradutor), de forma consciente, minimizá-los através de recursos como a complementação verbal, seja com adjetivos ou advérbios, para que o sentido original seja mantido e a tradução não apague as nuances do discurso.

Para analisar qualitativamente essa variação, no segundo momento, destaquei, nas tabelas a seguir, os termos dos campos lexicais do falar e do olhar, relacionados à opressão e à liberdade de ação, de fala e de pensamento.

Finalmente, após esta análise, apresentei uma tradução alternativa de alguns trechos, na qual seria possível manter as nuances discursivas do texto de partida.

\section{PARTE 2 - SPEAKING WITH OUR SPIRITS - BEFORE PALM SUNDAY "FALANDO COM NOSSOS ESPÍRITOS - ANTES DO DOMINGO DE RAMOS}

A segunda parte do livro é, como dito anteriormente, a primeira parte da história. Ela mostra como era a vida da família Achike antes da experiência de conviver com Ifeoma e os filhos em Nsukka: uma vida de riqueza material, com fartura de alimentos e 
uma casa de luxo. Mas, ao mesmo tempo, uma vida pobre de experiências, de ar, de liberdade e de vida; definida pelo medo.

Eugene é o opressor a quem todos temem e que jamais é questionado ou contrariado, sob pena de castigos severos. Beatrice é a esposa oprimida, que faz tudo para agradar o marido e é constantemente anulada por ele. Jaja é o adolescente que, a princípio, é inseguro e amedrontado. E Kambili tem uma mescla de medo e admiração pelo pai, um amor que suporta as dores e deseja estar perto dele, agradando-o ao máximo, pensando e agindo como ele.

A princípio, Kambili e Jaja não falam, apenas conversam através de olhares. Os irmãos têm uma linguagem secreta, a linguagem dos olhos: asusu anya. A seguir, selecionei alguns trechos em que essa linguagem acontece, com o intuito de avaliar a tradução.

Na Tabela 12, o verbo glance foi traduzido como "olhar". Porém, o significado do verbo em inglês não é neutro, como apresentado em português. No site do dicionário de Cambridge, ${ }^{35}$ a definição de glance é to give a quick short look, ou seja, "olhar rapidamente". A frase his eyes met mine demonstra um dos momentos em que os irmãos conversam em segredo pelo olhar. Ou seja, Jaja não encarou a irmã, como traduzido. Em um momento de tensão, os olhos dos irmãos se encontraram, pois partilhavam a mesma preocupação. Uma tradução mais significativa para o trecho poderia ser: "Senti um frio na barriga e olhei rapidamente para Jaja. Nossos olhos se encontraram. O que íamos dizer a Papa?"

Tabela 12: Linguagem do olhar entre Jaja e Kambili

\begin{tabular}{|l|l|}
\hline \multicolumn{1}{|c|}{ Purple hibiscus } & \multicolumn{1}{|c|}{ Hibisco roxo } \\
\hline I felt a lurch in my stomach and I glanced at & $\begin{array}{l}\text { Senti um frio na barriga e olhei para Jaja. Ele } \\
\text { Jaja. His eyes met mine. What would we tell } \\
\text { mencarou. O que íamos dizer a Papa? (p. } \\
\text { Papa? (p. 42) }\end{array}$ \\
\hline
\end{tabular}

Na Tabela 13, novamente, os olhares dos irmãos se encontram. A omissão do verbo "encontrar", meet, na tradução, oculta que a troca de olhares foi intencional, para, como em outros momentos, os dois conversarem. O piscar dos olhos de Kambili é parte

\footnotetext{
${ }^{35} \mathrm{O}$ site $<\mathrm{http}: / /$ dictionary.cambridge.org $>$ foi a fonte de referência para todos os verbos em língua inglesa apresentados nesta pesquisa. A opção por adotar o site foi por se tratar de um canal confiável de uma Universidade de prestígio, que contém informações completas como definição, sinônimos, antônimos, tradução e exemplos de cada verbete, e que está em constante atualização.
} 
dessa conversa silenciosa, e o irmão obedeceu à ordem dada, de permanecer em silêncio durante os cânticos.

Tabela 13: Linguagem do olhar entre Jaja e Kambili

\begin{tabular}{|c|c|}
\hline Purple hibi & Hib \\
\hline $\begin{array}{l}\text { My eyes met Jaja's. His eyes were watery, } \\
\text { full of suggestions. No! I told him, with a } \\
\text { tight blink. It was not right. You did not } \\
\text { break intosong in the middle of the rosary. I } \\
\text { did not join in the singing, and neither did } \\
\text { Jaja. (p. 64) }\end{array}$ & $\begin{array}{l}\text { Olhei nos olhos de } \\
\text { brilhantes, sugestivo } \\
\text { piscando os meus f } \\
\text { certo. Não se devia c } \\
\text { do rosário. Eu não ca } \\
\text { (p. } 63 \text { ) }\end{array}$ \\
\hline
\end{tabular}

Na Tabela 14, há um sinal interessante da evolução do personagem. Conforme Jaja vai conquistando autoconfiança e aprendendo a usar a própria voz, ele passa a evitar a linguagem do olhar com a irmã. Jaja não aceita mais o silêncio e, quando Kambili tenta se comunicar com ele nessa forma, ele olha para o outro lado, desvia o olhar, que é o significado do verbo look away. A tradução da ação como "virava o rosto" oculta, para o leitor do português, esse sinal. Look away está relacionado ao movimento do olhar, e não do rosto inteiro. É um movimento mais sutil e, ao mesmo tempo, mais significativo no contexto.

Tabela 14: Linguagem do olhar entre Jaja e Kambili

\begin{tabular}{|c|c|}
\hline Purple hibiscus & Hibisco roxo \\
\hline $\begin{array}{l}\text { Jaja and I did not talk about the many people } \\
\text { who came to the house. I wanted to talk } \\
\text { about it, but Jaja looked away when I } \\
\text { brought it up with my eyes, and he changed } \\
\text { the subject when I spoke of it. (p. } 99 \text { ) }\end{array}$ & $\begin{array}{l}\text { Jaja e eu não conversamos sobre as inúmeras } \\
\text { pessoas que vieram à nossa casa. Eu queria } \\
\text { fazê-lo, mas Jaja virava o rosto quando eu } \\
\text { trazia o assunto à baila com meus olhos, e } \\
\text { desconversava quando eu o mencionava. (p. } \\
\text { 103) }\end{array}$ \\
\hline
\end{tabular}

Em outras situações em que o verbo look away é usado na história, sobretudo em contextos que retratam medo e insegurança, a tradução usada é "desviar o olhar". Nesses momentos, a sutileza presente no campo lexical do ver, apresentando o desviar dos olhos como uma forma de fuga, é mantida na tradução.

No momento em que os netos visitam o avô, há, novamente, o encontro de olhares (o olhar do avô encontra o da neta enquanto ela o examina; ele não a encara, como foi expresso na tradução). Visto que o avô é considerado um pagão impuro, Kambili fica apreensiva e desvia o olhar (Tabela 15). 
Tabela 15: Verbo look away significando fuga

\begin{tabular}{|l|l|}
\hline \multicolumn{1}{|c|}{ Purple hibiscus } & \multicolumn{1}{|c|}{ Hibisco roxo } \\
\hline I had examined him that day, too, looking & Naquele dia eu também examinara Papa- \\
away when his eyes met mine, for signs of & Nukwu, desviando o olhar quando ele me \\
difference, of Godlessness. I didn't see any, & encarava, procurando por um sinal que \\
but I was sure they were there somewhere. & $\begin{array}{l}\text { marcasse sua diferença, sua condição de } \\
\text { pessoa ímpia. Não vi nenhum, mas estava } \\
\text { They had to be. (p. 34) }\end{array}$ \\
& $\begin{array}{l}\text { certa de que eles deviam estar em algum } \\
\text { lugar. Tinham de estar. (p. 33) }\end{array}$ \\
\hline
\end{tabular}

A insegurança faz com que Kambili desvie o olhar não apenas de Papa-Nnukwu, mas também de sua tia Ifeoma, no princípio da história. Quando a tia tem atitudes expansivas, fala com os sobrinhos sem rodeios, com humor, a menina se retrai e desvia o olhar, como uma forma de fuga (Tabela 16).

Tabela 16: Verbo look away significando fuga

\begin{tabular}{|l|l|}
\hline \multicolumn{1}{|c|}{ Purple hibiscus } & \multicolumn{2}{|c|}{ Hibisco roxo } \\
\hline $\begin{array}{l}\text { I looked away and inhaled deeply so that I } \\
\text { would not start to stutter. I did not know how } \\
\text { to handle that kind of playfulness. (p. 38) }\end{array}$ & $\begin{array}{l}\text { Desviei o olhar e respirei fundo, tentando não } \\
\text { gaguejar. Não sabia como lidar com } \\
\text { brincadeiras daquele tipo. (p.33) }\end{array}$ \\
\hline
\end{tabular}

O olhar de Kambili também foge de padre Amadi, por quem a menina começa a nutrir um sentimento romântico. Na Tabela 17, mais uma vez, o encontro de olhares, expresso em inglês pelo verbo meet, é traduzido como "encarar".

Tabela 17: Encontro de olhares

\begin{tabular}{|l|l|}
\hline \multicolumn{1}{|c|}{ Purple hibiscus } & \multicolumn{1}{c|}{ Hibisco roxo } \\
\hline It seemed so ungodly, so common. Father & Era uma atividade tão ímpia, tão ordinária. O \\
Amadi'seyes met mine across the table, and I & $\begin{array}{l}\text { padre Amadi me encarou do outro lado da } \\
\text { mesa e eu desviei o olhar depressa. (p. 75) }\end{array}$ \\
\hline
\end{tabular}

O site Dicionário Online de Português ${ }^{36}$ define "encarar" como "olhar fixamente para o rosto de alguém, olhar nos olhos, analisar atenciosamente, examinar, confrontar algo ou alguém." Pelo contexto (uma refeição em família) e pela importância que o olhar tem nessa parte da história, é fácil perceber que o padre não "olhou fixamente" para Kambili nem a "confrontou". Sendo assim, a melhor tradução seria "os olhos do padre Amadi encontraram os meus, do outro lado da mesa." Já a parte seguinte do trecho, "desviei o olhar depressa", foi uma escolha acertada na tradução, pois demonstra

\footnotetext{
${ }^{36} \mathrm{O}$ site www.dicio.com.br foi a fonte de consulta de todos os termos em língua portuguesa apresentados nesta pesquisa.
} 
que não houve qualquer movimento para além dos olhos. A timidez é que faz com que Kambili olhe em outra direção.

No campo lexical do falar, predominam, no início da história, o silêncio, o murmúrio e as falas, que apenas reproduzem a visão do pai e têm o objetivo de conquistar sua aprovação.

Um exemplo dessa necessidade de aprovação está na Tabela 18.

Tabela 18: Fala de Kambili com o intuito de agradar o pai

\begin{tabular}{|l|l|}
\hline \multicolumn{1}{|c|}{ Purple hibiscus } & \multicolumn{1}{c|}{ Hibisco roxo } \\
\hline $\begin{array}{l}\text { "God will deliver us," I said, knowing Papa } \\
\text { would like my saying that. (p. 16) }\end{array}$ & - Deus nos salvará - disse eu, sabendo que \\
Papa gostaria de ouvir isso. (p. 15)
\end{tabular}

$\mathrm{Na}$ língua inglesa, o gerúndio (também denominado present participle) altera a função gramatical da forma verbal, que passa a funcionar como substantivo. No trecho de Purple hibiscus, saying é precedido do adjetivo possessivo my, que é o principal elemento da frase. O possessivo indica que o orgulho do pai não viria da afirmação God will deliver us em si, mas, sim, do fato de Kambili ter dito aquilo. Na tradução, o foco foi alterado, pois o uso do verbo "ouvir" dá a entender que o pai gostaria de ouvir a frase, sem importar quem a tivesse dito. Uma tradução alternativa para o trecho, que manteria o enfoque na filha, poderia ser "eu disse, sabendo que Papa iria gostar de me ouvir dizer aquilo".

A voz embargada e a dificuldade em falar, causadas pela opressão, são perceptíveis pelos verbos usados para iniciar as falas de mãe e filha. No trecho a seguir, Tabela 19, em uma das poucas ocasiões em que Beatrice se dirige ao marido, o verbo usado é mumble, definido pelo dicionário de Cambridge como "falar baixo e de forma intrincada para que as palavras fiquem difíceis de entender" ${ }^{37} \mathrm{O}$ verbo foi traduzido como "murmurar", cuja definição no Dicionário Online de Português é "produzir som surdo e prolongado, falar baixinho, de forma inaudível, pronunciar em voz baixa, contar em segredo, criticar”. Essa foi a tradução acertadamente usada nas quatro entradas da palavra no livro.

\footnotetext{
37 "to speak quietly and in a way that is not clear so that the words are difficult to understand".
} 
Tabela 19: Diálogo entre Beatrice e Eugene

\begin{tabular}{|l|l|}
\hline \multicolumn{1}{|c|}{ Purple hibiscus } & \multicolumn{1}{|c|}{ Hibisco roxo } \\
\hline $\begin{array}{l}\text { "My body does not feel right," she mumbled. } \\
\text { "I asked if you were sure you wanted to stay }\end{array}$ & - Meu corpo não está bem - murmurou ela. \\
in the car." & quer ficar nontei se você tem certeza de que qua olhou para ele. \\
$\begin{array}{l}\text { Mama looked up. "I'll come with you. It's } \\
\text { really not that bad."(p. 18) }\end{array}$ & $\begin{array}{l}\text { - Não, eu vou com vocês. Não está tão ruim } \\
\text { assim. (p. 16) }\end{array}$ \\
\hline
\end{tabular}

A fala de Kambili no início da história, assim como a de sua mãe, é limitada pela opressão. Mesmo quando não está falando com o pai, a menina se sente insegura com os demais interlocutores, e, por diversas vezes, aparecem os verbos stutter e cough, traduzidos como "gaguejar" e "tossir", respectivamente, e também o substantivo cough, “tosse". Como é demonstrado na Tabela 20, quando, insegura para responder às perguntas da prima Amaka, tosse forçadamente (ação que se repete em diversas ocasiões).

Tabela 20: Tosse forçada de Kambili

\begin{tabular}{|l|l|}
\hline \multicolumn{1}{|c|}{ Purple hibiscus } & \multicolumn{1}{|c|}{ Hibisco roxo } \\
\hline $\begin{array}{l}\text { I forced a cough out of my throat; I hoped I } \\
\text { would not stutter. (p. 41) }\end{array}$ & $\begin{array}{l}\text { Dei uma tosse forçada; torci para não } \\
\text { gaguejar. (p. 40) }\end{array}$ \\
\hline
\end{tabular}

Os termos do campo lexical do falar, quando se referem à família de Ifeoma, denotam uma fala expansiva, risadas, voz em um tom alto. Alguns termos recorrentes são: voice, laugh, speak. Também são recorrentes as frases no imperativo ditas por Ifeoma, o que demonstra ser uma mulher audaciosa, ao contrário de Kambili e Beatrice. A primeira sensação de Kambili diante do ambiente da família da tia é o incômodo. As vozes, risadas e conversas a perturbam, e seu desejo é fazê-los calar (Tabela 21).

Tabela 21: Descrição do modo de falar de Ifeoma

\begin{tabular}{|l|l|}
\hline \multicolumn{1}{|c|}{ Purple hibiscus } & \multicolumn{1}{|c|}{ Hibisco roxo } \\
\hline Every time Aunty Ifeoma spoke to Papa, my & Toda vez que tia Ifeoma se dirigia a Papa, \\
heart stopped, then started again in a hurry. It & meu coração parava e depois começava a \\
was the flippant tone; she did not seem to & bater de novo, freneticamente. Era por causa \\
recognize that it was Papa, that he was & daquele tom atrevido; ela não parecia \\
different, special. I wanted to reach out and & reconhecer que aquele era Papa, que ele era \\
press her lips shut and get some of that shiny & $\begin{array}{l}\text { diferente, especial. Tive vontade de apertar } \\
\text { bronze lipstick on my fingers. (p. 40) }\end{array}$ \\
& $\begin{array}{l}\text { os lábios dela para fechá-los, e também para } \\
\text { pegar um pouco de batom cor de bronze nos } \\
\text { dedos. (p. 40) }\end{array}$ \\
\hline
\end{tabular}

Porém, em seguida, ela também começa a desejar ser assim: livre, falante, irreverente - flippant -, como sua prima e as amigas. O desejo de falar é embargado, 
novamente, pela tosse forçada. Assim como os verbos cough e stutter, as frases I wanted to say e I wanted to tell se repetem no discurso de Kambili, no início da história (Tabela 22).

Tabela 22: Kambili expressa seu desejo de falar

\begin{tabular}{|c|c|}
\hline Purple hibiscus & Hibisco roxo \\
\hline $\begin{array}{l}\text { I wanted to tell the girls that it was all my } \\
\text { hair, that there were no attachments, but the } \\
\text { words would not come. I knew they were } \\
\text { still talking about hair, how long and thick } \\
\text { mine looked. I wanted to talk with them, to } \\
\text { laugh with them so much that I would start } \\
\text { to jump up and down in one place the way } \\
\text { they did, but my lips held stubbornly } \\
\text { together. I did not want to stutter, so I } \\
\text { started to cough and then ran out and into the } \\
\text { toilet. (p. } 71 \text { ) }\end{array}$ & $\begin{array}{l}\text { Queria dizer às meninas que meu cabelo era } \\
\text { de verdade, que eu não usava extensões, mas } \\
\text { as palavras não saíam. Eu sabia que elas } \\
\text { ainda estavam conversando sobre cabelo, } \\
\text { comentando como o meu era comprido e } \\
\text { cheio. Queria conversar com elas, rir com } \\
\text { elas, rir tanto até começar a pular no } \\
\text { mesmo lugar como elas faziam, mas meus } \\
\text { lábios insistiram em permanecer fechados. } \\
\text { Como eu não quis gaguejar, comecei a tossir e } \\
\text { corri para o banheiro. (p. } 71 \text { ) }\end{array}$ \\
\hline
\end{tabular}

No campo lexical do olhar, os verbos, advérbios e adjetivos referentes ao modo de olhar de Ifeoma e dos primos também são mais assertivos, principalmente os de Amaka. Kambili descreve os olhos da prima como quizzical eyes (p. 41) - "olhos interrogativos" na versão em português. A tradução do adjetivo quizzical por "questionadores" daria uma carga semântica mais forte à descrição do olhar.

Por diversas vezes no texto, Amaka observa os primos com estranheza. Três verbos são usados para retratar a ação: glance, bore into e look at, e todos foram traduzidos por "olhar" em Hibisco roxo. A diferenciação dessas nuances, no português, teria de ser feita com a complementação de advérbios ou com o uso de locuções. No caso do verbo look, o próprio texto de partida já contém essa complementação, como no trecho a seguir (Tabela 23).

Tabela 23: Descrição do olhar de Amaka

\begin{tabular}{|c|c|}
\hline Purple hibiscus & Hibisco roxo \\
\hline $\begin{array}{l}\text { "What are you doing?" } \\
\text { I jumped. "Nothing." } \\
\text { She was looking at me oddly, right in the } \\
\text { eye. (p. } 50 \text { ) }\end{array}$ & $\begin{array}{l}\text { - O que você está fazendo? } \\
\text { Dei um pulo de susto. } \\
\text { - Nada. } \\
\text { Ela me olhava de um jeito estranho, bem } \\
\text { nos olhos. (p. } 49 \text { ) }\end{array}$ \\
\hline
\end{tabular}

Na tabela 24, há o caso de glance ("olhar rapidamente"), no qual não houve complementação. Após uma piada do avô, todos os primos riem, mas Kambili e Jaja permanecem sérios. Uma inserção possível na tradução seria "Amaka deu uma olhada 
rápida para Jaja e para mim" ou "Amaka olhou de relance para Jaja e para mim por um segundo".

Tabela 24: Descrição do olhar de Amaka

\begin{tabular}{|l|l|}
\hline \multicolumn{1}{|c|}{ Purple hibiscus } & \multicolumn{1}{c|}{ Hibisco roxo } \\
\hline $\begin{array}{l}\text { My cousins laughed, and Amaka glanced at } \\
\text { Jaja and me, perhaps wondering why we did } \\
\text { not laugh, too. (p. 43) }\end{array}$ & $\begin{array}{l}\text { Meus primos riram, e Amaka olhou para } \\
\text { Jaja e para mim, talvez achando estranho não } \\
\text { rirmos também. (p. 43) }\end{array}$ \\
\hline
\end{tabular}

O verbo bore into também contém uma carga de significado que pede complementação no português. A definição do verbo bore no dicionário é to make a hole in something using a tool - "perfurar"; e a explicação para bore into é "se os olhos de alguém bore into, eles olham para você de uma maneira muito dura que te deixa nervoso". ${ }^{38}$ Unindo ambas as definições, uma tradução mais significativa para a "ação" seria "Amaka continuava me fuzilando com os olhos" (Tabela 25).

Tabela 25: Descrição do olhar de Amaka

\begin{tabular}{|l|l|}
\hline \multicolumn{1}{|c|}{ Purple hibiscus } & \multicolumn{1}{|c|}{ Hibisco roxo } \\
\hline $\begin{array}{l}\text { "I was happy that he came to the hospital," I } \\
\text { said. It felt easy saying that, letting the words } \\
\text { roll off my tongue. Amaka's eyes still bored } \\
\text { into me. (p. 106) }\end{array}$ & $\begin{array}{l}\text { Foi fácil dizer isso, deixar as palavras } \\
\text { jorrarem da boca. Os olhos de Amaka ainda } \\
\text { estavam fixos em mim. (p. 110) }\end{array}$ \\
\hline
\end{tabular}

Diversas passagens do livro demonstram a importância de Ifeoma na formação da identidade de Kambili e na descoberta de sua voz. Um desses momentos é a briga em que a tia intervém, quando a prima Amaka ofende a menina com palavras agressivas e uma atitude hostil. Em vezes anteriores, Ifeoma saiu em defesa da sobrinha. Mas, dessa vez, ela incita a menina a reagir com a própria voz. Na Tabela 26, mais uma ordem de Ifeoma, no imperativo, e verbos frasais do campo lexical do falar, com forte carga semântica.

Tabela 26: Descrição do olhar e do falar de Ifeoma

\begin{tabular}{|l|l|}
\hline \multicolumn{1}{|c|}{ Purple hibiscus } & \multicolumn{1}{|c|}{ Hibisco roxo } \\
\hline "Yes. Don't you know how to prepare orah?" & - Isso. Não sabe preparar orah? \\
I shook my head. "No, Aunty." & Balancei a cabeça. \\
"Amaka will do it, then," Aunty Ifeoma said. & - Não, tia. \\
$\begin{array}{l}\text { She unfolded and refolded her wrapper around } \\
\text { her waist, knotting it at her side. }\end{array}$ & $\begin{array}{l}\text { - Então a Amaka faz - disse tia Ifeoma, } \\
\text { tirando a canga da cintura e amarrando-a de }\end{array}$ \\
\hline
\end{tabular}

\footnotetext{
38 "If someone's eyes bore into you, they look at you very hard and make you feel nervous."
} 
"Why?" Amaka burst out. "Because rich novo.

people do not prepare orah in their houses? - Por quê? - gritou Amaka. - Porque gente Won't she participate in eating the orah rica não prepara orah na casa deles? Ela não soup?"

Aunty Ifeoma's eyes hardened - she was not looking at Amaka, she was looking at me. "O ginidi, Kambili, have you no mouth? Talk back to her!'”(p. 84)

vai comer a sopa de orah também?

Tia Ifeoma lançou um olhar furioso - não para Amaka, mas para mim.

- O ginidi, Kambili, você não tem boca? Não deixe Amaka sem resposta! (p. 85)

O verbo burst out, traduzido como "gritar", perdeu muito de seu significado, pois "gritar" é um verbo neutro, que não tem a mesma carga, e burst out faz referência a uma erupção, uma explosão. No caso, numa explosão de revolta de Amaka, que se sentiu lesada por ter que cumprir as obrigações da prima. A indignação expressa na pergunta "Why?" vai além de um mero grito. Para que esse significado não se perca, seria interessante complementar a ação com adjetivos ou advérbios, além de substituir o verbo por "berrar" - “Amaka berrou: Por que eu?", ou "Indignada, Amaka deu um berro: Por que eu?", ou substituir a pergunta por uma afirmação categórica que marcaria bem a personalidade da adolescente: "Eu, não! - berrou Amaka."

A reação de Ifeoma ao ver sua filha humilhar Kambili - o "olhar furioso", muito bem colocado pela tradutora, e a frase Talk back to her! - têm o objetivo de incitar na sobrinha a indignação e fazer brotar nela a coragem para insurgir-se. Não era a primeira vez que Kambili se sujeitava às palavras ofensivas da prima. $\mathrm{O}$ imperativo e os verbos usados têm uma carga que é suavizada na tradução "Não deixe Amaka sem resposta!", que seria mais intensa como "Não deixe Amaka te tratar assim!", ou "Faça alguma coisa, não deixe que ela fale assim de você!", ou até mesmo "Reaja, Kambili! Você tem que revidar!"

Com a convivência com a família da tia, Kambili adquire uma nova voz, que é, por vezes, desconhecida pela própria menina. Ela estava tão condicionada a permanecer em silêncio que não conhecia o som da sua risada, nem do seu choro, e fica surpresa quando ouve o próprio som. Ao final da primeira parte da história, Kambili, Jaja e Beatrice começam a se tornar sujeitos de outros verbos do campo lexical do falar, como se pode ver nos exemplos da Tabela 27. 
Tabela 27: Verbos do campo lexical do falar cujo sujeito é Kambili

\begin{tabular}{|c|c|}
\hline Purple hibiscus & Hibisco roxo \\
\hline $\begin{array}{l}\text { I laughed. It sounded strange, as if I were } \\
\text { listening to the recorded laughter of a stranger } \\
\text { being played back. I was not sure I had ever } \\
\text { heard myself laugh. (p. } 89 \text { ) }\end{array}$ & $\begin{array}{l}\text { Eu ri. O som foi esquisito, como se eu } \\
\text { estivesse ouvindo a risada de um estranho } \\
\text { numa gravação. Acho que nunca tinha me } \\
\text { ouvido rir antes. (p. } 90 \text { ) }\end{array}$ \\
\hline $\begin{array}{l}\text { I did not know that the sobbing voice "I'm } \\
\text { sorry! I'm sorry!"- was mine until the water } \\
\text { stopped and I realized my mouth was moving } \\
\text { and the words were still coming out. (p. 96) }\end{array}$ & $\begin{array}{l}\text { Eu não sabia que aquela voz que soluçava - } \\
\text { Desculpe! Desculpe! - era minha até que a } \\
\text { água parou de cair e percebi que minha boca } \\
\text { se movia e as palavras ainda saíam por ela. (p. } \\
\text { 98) }\end{array}$ \\
\hline
\end{tabular}

O silêncio, a partir daí, já não é sinal de opressão, mas, sim, de independência e de personalidade. Inicia-se a formação da autonomia, quando Kambili, Jaja e Beatrice percebem que podem decidir falar ou calar. Calar-se, assim como fechar os olhos, passa, então, a ser não uma fuga, mas um enfrentamento. Não há mais sussurros nem murmúrios, mas, sim, os primeiros momentos em que surge a fala afirmativa e o silêncio de quem já não aceita submeter-se nem falar apenas para concordar e agradar: a semente da liberdade foi plantada (Tabela 28).

Tabela 28: Exemplos de desvio do olhar como atitude assertiva

\begin{tabular}{|l|l|}
\hline \multicolumn{1}{|c|}{ Purple hibiscus } & \multicolumn{1}{c|}{ Hibisco roxo } \\
\hline $\begin{array}{l}\text { "My precious daughter. Nothing will happen } \\
\text { to you. My precious daughter." I was not sure } \\
\text { if it was a dream. I closed my eyes. (p. 100) }\end{array}$ & $\begin{array}{l}\text { - Minha filha preciosa. Nada vai acontecer } \\
\text { com você. Minha filha preciosa. } \\
\text { Eu não sabia se aquilo era um sonho. Fechei } \\
\text { os olhos. (p. 106) }\end{array}$ \\
\hline $\begin{array}{l}\text { "Your father has been by your bedside every } \\
\text { night these past three days. He has not slept a } \\
\text { wink." }\end{array}$ & $\begin{array}{l}\text { Seu pai passou as últimas três noites na } \\
\text { cabeceira de sua cama. Ele não dormiu nem } \\
\text { lt was hard to turn my head, but I did it and } \\
\text { looked away. (p. 104) }\end{array}$ \\
$\begin{array}{l}\text { um minuto. } \\
\text { Foi difícil virar a cabeça para o outro lado, } \\
\text { mas eu o fiz mesmo assim. (p. 108) }\end{array}$ \\
\hline
\end{tabular}

No reencontro com o pai, que cometeu um ato de violência brutal, Kambili se recusa a olhar para ele. Ela não enfrenta o pai verbalmente, mas com desprezo. Nesse momento, o ato de fechar os olhos já não é sinal de medo, mas de coragem. Mais uma vez é usado o verbo look away, omitido na tradução. Uma tradução alternativa para a última frase, com enfoque no campo lexical do olhar, seria "mesmo com dificuldade, eu virei a cabeça e desviei o olhar”. O olhar se desvia para mostrar-se livre, como demonstração de que a visão está ampliada e vai além da imagem do opressor diante do oprimido. 


\section{PARTE 1 - BREAKING GODS - PALM SUNDAY \\ QUEBRANDO DEUSES - ANTES DO DOMINGO DE RAMOS}

A primeira parte do livro mostra a sequência da história, a ruptura que acontece após a estadia em Nsukka e a liberdade que começa a germinar. A "quebra dos deuses" pode ser interpretada como a quebra de paradigmas familiares e religiosos. Jaja é o primeiro a se rebelar, recusando-se a participar da comunhão na igreja, criticando os elementos sagrados e o ritual perante o seu pai e mostrando a ele que não vai mais se submeter à sua autoridade (Tabela 29).

Tabela 29: Verbo do campo lexical do olhar como atitude assertiva

\begin{tabular}{|c|c|}
\hline & \\
\hline $\begin{array}{l}\text { o to communion," Papa } \\
\text { question. } \\
\text { missal on the table as }\end{array}$ & $\begin{array}{l}\text { com ele. } \\
\text { missal sobre a mesa, como } \\
\text { ne mau hálito. (p. } 6 \text { ) }\end{array}$ \\
\hline
\end{tabular}

No campo lexical do olhar, o verbo mais frequente nessa parte do livro é stare, definido no dicionário de Cambridge como "olhar por um longo tempo com olhos bem abertos, especialmente quando surpreso, assustado ou pensando", ${ }^{39}$ ou seja, um olhar fixo, demorado, de olhos bem abertos. Em Hibisco roxo, é traduzido por "olhar" e por "encarar". Traduzir somente como "olhar", como no exemplo acima, atenua o significado do verbo. É necessário um complemento para que a ideia original desse olhar se mantenha. No caso a seguir, Tabela 30, a tradutora optou por usar o adjetivo "atônita" para transmitir essa ideia, que foi uma boa escolha.

Tabela 30: Linguagem do olhar entre Jaja e Kambili

\begin{tabular}{|l|l|}
\hline \multicolumn{1}{|c|}{ Purple hibiscus } & \multicolumn{1}{|c|}{ Hibisco roxo } \\
\hline $\begin{array}{l}\text { I stared at Jaja. Had something come loose in } \\
\text { his head? (p. 7) }\end{array}$ & $\begin{array}{l}\text { - Eu olhei atônita para Jaja. Será que ele } \\
\text { tinha ficado maluco? (p. 6) }\end{array}$ \\
\hline
\end{tabular}

Jaja, pela primeira vez, desafia a autoridade do pai. O adolescente não age como esperado, não fala nem se cala quando deveria. Torna-se defiant - "rebelde" - como o personagem histórico Jaja of Oprobo que Ifeoma lhe apresentou. Kambili também tenta algumas vezes falar com ele pela linguagem do olhar, mas o retorno é sempre negativo:

\footnotetext{
39 "to look for a long time with the eyes wide open, especially when surprised, frightened, or thinking".
} 
He did not look at me (p. 7). Na Tabela 31, a seguir, apresento um exemplo desse olhar enfrentador de Jaja para o pai.

Tabela 31: Verbo do campo lexical do olhar como atitude assertiva

\begin{tabular}{|c|c|}
\hline Purple hibiscus & Hibisco roxo \\
\hline $\begin{array}{l}\text { Papa was staring pointedly at Jaja. "Jaja, } \\
\text { have you not shared a drink with us, gbo? } \\
\text { Have you no words in your mouth?" (p. 10) } \\
\text { "Mba, there are no words in my mouth," Jaja } \\
\text { replied. "Have you nothing to say, gbo, Jaja?" } \\
\text { Papa asked again. } \\
\text { "Mba, there are no words in my mouth," Jaja } \\
\text { replied. } \\
\text { "What?" There was a shadow clouding Papa's } \\
\text { eyes, a shadow that had been in Jaja's eyes. } \\
\text { Fear. It had left Jaja's eyes and entered } \\
\text { Papa's. "I have nothing to say," Jaja said. (p. } \\
\text { 10) }\end{array}$ & $\begin{array}{l}\text { Papa olhava fixamente para Jaja. } \\
\text { - Jaja, você não bebeu conosco, gbo? Não há } \\
\text { palavras em sua boca? (p. 9) } \\
\text { - Você não tem nada a dizer, gbo, Jaja? - } \\
\text { perguntou Papa novamente. } \\
\text { - Mba, não há palavras em minha boca - } \\
\text { respondeu Jaja. } \\
\text { - O quê? } \\
\text { Havia uma sombra enegrecendo os olhos de } \\
\text { Papa, a mesma sombra que estivera nos olhos } \\
\text { de Jaja. Medo. O medo deixara os olhos de } \\
\text { Jaja e entrara nos de Papa. (p. 10) }\end{array}$ \\
\hline
\end{tabular}

O modo como Eugene olha para o filho, a expressão staring pointedly (p. 10), traduzida como "olhar fixamente", demonstra mais que um olhar fixo: um olhar crítico, de cobrança, que quer enfatizar e chamar a atenção, expressa pelo advérbio pointely (na definição do dicionário de Cambridge: "de uma forma óbvia, geralmente para expressar crítica ou reprovação" ${ }^{40}$ ). Para transmitir essa mesma interpretação em português, a frase poderia ser traduzida como "Papa encarou Jaja firmemente, com um olhar reprovador".

No campo lexical do falar, aparece o verbo reply - "responder" -, do qual Jaja é o sujeito. Contudo, Kambili ainda mantém-se insegura para verbalizar seu pensamento. Aparecem, por diversas vezes, as expressões I wanted to say e I meant to say (Tabela $32)$.

Tabela 32: Kambili expressa seu desejo de falar

\begin{tabular}{|l|l|}
\hline \multicolumn{1}{|c|}{ Purple hibiscus } & \multicolumn{1}{|c|}{ Hibisco roxo } \\
\hline I meant to say I am sorry Papa broke your & Eu quis dizer que sentia muito por Papa ter \\
figurines, but the words that came out were, & quebrado as estatuetas dela, mas as palavras \\
"I'm sorry your figurines broke, Mama." She & que saíram foram: \\
nodded quickly, then shook her head to & - Sinto muito que suas estatuetas tenham \\
show that the figurines did not matter. (p. & $\begin{array}{l}\text { quebrado, Mama. } \\
\text { 9) }\end{array}$ \\
& $\begin{array}{l}\text { Ela assentiu rapidamente, e depois } \\
\text { balançou a cabeça para indicar que as } \\
\text { estatuetas não eram importantes. (p. 8) }\end{array}$ \\
\hline
\end{tabular}

40 "in a very obvious way, usually to express criticism or disapproval". 
Kambili fica impressionada e assiste, chocada e "atônita" - como bem descreve a tradutora -, às atitudes do irmão. A mãe também já dá sinais de que não é a mesma. Duas semanas antes, ela "rearrumara as estatuetas" (p. 8), já tinha trocado a posição das bailarinas: um pequeno sinal de que a mudança havia começado. Depois, com um gesto, sinaliza à filha que as bailarinas, símbolo da violência que sofria, já não eram importantes. Assim como Kambili, Beatrice não verbaliza pensamentos e sentimentos.

O fato de Jaja, o personagem masculino, ser o primeiro a enfrentar o pai pode ser interpretado como um indício de que a submissão está cultural e socialmente mais arraigada às mulheres, e que, para elas, escapar da subjugação seria mais difícil. A voz de Jaja, sua liberdade, começa a brotar, timidamente, enquanto Kambili e Beatrice ainda internalizam seu desejo de viverem de outra forma.

\section{PARTE 3 - THE PIECES OF GOD (AFTER PALM SUNDAY) OS PEDAÇOS DE DEUSES - APÓS O DOMINGO DE RAMOS}

Na tradição católica, o Domingo de Ramos é o dia em que se inicia a Semana Santa. É a liturgia que relembra a entrada de Cristo na cidade de Jerusalém, saudado pelo povo, que forrou o chão com palmas para celebrar. O Domingo de Ramos marca a última semana da Quaresma, tempo de preparação para a Páscoa, em que os fiéis praticam jejum e penitência e relembram a crucificação de Cristo. O simbolismo da Semana Santa, para os cristãos, contém a mensagem do sacrifício e da morte, mas também a mensagem de esperança e renascimento, com a Páscoa. A terceira parte do livro - após o Domingo de Ramos - é a história do renascimento de Kambili, Jaja e Beatrice.

A frase "Everything came tumbling down after Palm Sunday" (p. 124), que inicia o capítulo, relembra a primeira frase do livro. Os verbos tumble down e fall apart trazem a ideia de "quebra", "ruína”, "destruição". Assim como as bailarinas decorativas, tudo está em pedaços, inclusive a Nigéria, que acabara de sofrer um golpe militar. $\mathrm{Na}$ casa dos Achike, também, metaforicamente, os pilares vieram abaixo.

O pai não é mais um homem indestrutível. A descrição de seu corpo franzino, fraco, com feridas causadas pelo envenenamento, reflete também na sua fala. Não há mais ordens, frases no imperativo, vindas de Eugene. Ele se limita a pedir - ask - e, mesmo assim, não é obedecido pelo filho (Tabela 33). 
Tabela 33: Mudança dos verbos usados para introduzir a fala de Eugene

\begin{tabular}{|c|c|}
\hline Purple hibiscus & Hibisco roxo \\
\hline $\begin{array}{l}\text { Jaja did not come out of his room even though } \\
\text { Papa asked him to. The first time Papa } \\
\text { asked him, the day after Palm Sunday, Papa } \\
\text { could not open his door because he had } \\
\text { pushed his study desk infront of it. (p. 124) }\end{array}$ & $\begin{array}{l}\text { Jaja não saiu do quarto, embora Papa tenha } \\
\text { lhe pedido que o fizesse. Na primeira vez em } \\
\text { que Papa lhe pediu isso, no dia seguinte ao } \\
\text { Domingo de Ramos, ele tentou abrir a porta de } \\
\text { Jaja, mas não conseguiu, pois Jaja colocara a } \\
\text { escrivaninha na frente dela. (p. 128) }\end{array}$ \\
\hline
\end{tabular}

A mãe não é mais apenas o objeto das ações, mas o sujeito das orações. Após a morte do opressor, não precisa mais sussurrar, e esboça até um discreto sorriso (Tabela $34)$.

Tabela 34: Início da conquista da voz de Beatrice

\begin{tabular}{|c|c|}
\hline Purple hibiscus & Hibisco roxo \\
\hline $\begin{array}{l}\text { When Mama asked Sisi to wipe the floor of } \\
\text { the living room, to make sure no dangerous } \\
\text { pieces of figurines were left lying somewhere, } \\
\text { she did not lower her voice to a whisper. } \\
\text { She did not hide the tiny smile that drew } \\
\text { lines at the edge of her mouth. She did not } \\
\text { sneak Jaja's food to his room, wrapped in } \\
\text { cloth so it would appear that she had simply } \\
\text { brought his laundry in. She took him his food } \\
\text { on a white tray, with a matching plate. (p. } \\
\text { 124) }\end{array}$ & $\begin{array}{l}\text { Quando Mama pediu que Sisi varresse o chão } \\
\text { da sala de estar, para ter certeza de que } \\
\text { nenhum fragmento perigoso das estatuetas } \\
\text { ainda estivesse oculto em algum lugar, ela } \\
\text { não baixou a voz. Não escondeu o } \\
\text { minúsculo sorriso que formava covinhas } \\
\text { nos cantos de sua boca. Não levou a comida } \\
\text { até o quarto de Jaja escondida num pedaço de } \\
\text { pano para que parecesse que estava apenas } \\
\text { carregando a roupa limpa dele. Levou a } \\
\text { comida numa bandeja branca e num prato da } \\
\text { mesma cor. (p. 124) }\end{array}$ \\
\hline
\end{tabular}

Nessa parte da história, é interessante perceber que os verbos do campo lexical do falar relacionados à timidez e à intimidação, como whisper e mutter - "sussurrar" e "murmurar" -, não são mais usados em referência aos personagens anteriormente oprimidos. Com a conquista da voz pelas mulheres, o murmúrio, a linguagem corporal, o "dar de ombros", agora se referem aos opressores. O motorista Kevin, lacaio do pai, assim como seu patrão, já não é temido, e tem que obedecer às ordens de Jaja.

Kevin leva os irmãos a contragosto, e é ele quem permanece em silêncio durante a viagem, e não todos os ocupantes do carro, como dá a entender a tradução "permanecemos" (Tabela 35).

Tabela 35: Linguagem corporal e do olhar de Kevin

\begin{tabular}{|l|l|}
\hline \multicolumn{1}{|c|}{ Purple hibiscus } & \multicolumn{1}{|c|}{ Hibisco roxo } \\
\hline $\begin{array}{l}\text { Kevin shrugged, and muttered, "This kind } \\
\text { of trip, can't you go tomorrow?" before }\end{array}$ & Kevin deu de ombros e murmurou: - Uma \\
starting the car. He remained silent throughout & Mas ele ligou o o motor do carro. \\
the drive, and I saw his eyes often dart to us, & Permanecemos em silêncio a viagem toda e vi \\
\hline
\end{tabular}


mostly to Jaja, in the rearview mirror." (p. 126) que Kevin olhou muitas vezes para nós, e principalmente para Jaja, pelo retrovisor. (p. 130)

Os verbos da frase I saw his eyes often dart to us também estão relacionados ao campo lexical do olhar e, como nos casos anteriores, não têm o significado neutro de "olhar". To dart a glancel a look at somebody significa, de acordo com o dicionário de Cambridge, to look quickly at someone - "olhar para alguém rapidamente". Não há nuances de intenção ou de sentimentos, apenas quanto à velocidade e à direção certeira, como um "dardo" - dart. Uma tradução alternativa para a última frase seria "Ele ficou calado a viagem inteira, e eu percebi seus olhos nos espiando pelo retrovisor várias vezes".

Após o Domingo de Ramos, Kambili aparece por diversas vezes como sujeito de dois verbos do campo lexical do falar: "cantar" (sing) e "rir" (laugh) (Tabela 36). Ela canta durante o banho e não se importa de cantar na frente da prima, que exclama admirada: "You are singing along, [...]" (p. 132).

Tabela 36: Kambili como sujeito de verbos do campo lexical do falar

\begin{tabular}{|l|l|}
\hline \multicolumn{1}{|c|}{ Purple hibiscus } & \multicolumn{1}{|c|}{ Hibisco roxo } \\
\hline $\begin{array}{l}\text { I laughed. I laughed because the allamanda } \\
\text { flowers were so yellow. I laughed imagining }\end{array}$ & $\begin{array}{l}\text { Eu ri. Ri porque as alamandas eram bem } \\
\text { amarelas. Ri de imaginar o gosto ruim que seu }\end{array}$ \\
how bitter their white juices would taste if & $\begin{array}{l}\text { suco branco teria se o padre Amadi realmente } \\
\text { Father Amadi had really sucked them. I }\end{array}$ \\
$\begin{array}{l}\text { laughed because Father Amadi's eyes were so } \\
\text { brown I could see my reflection in them. (p. }\end{array}$ & padre Amadi eram tão castanhos que eu podia \\
129) & ver meu reflexo neles. (p. 134) \\
\hline
\end{tabular}

\section{PARTE 4 - A DIFFERENT SILENCE - THE PRESENT}

\section{UM SILÊNCIO DIFERENTE - O PRESENTE}

A última parte do livro mostra a nova realidade da família, completando o ciclo do hibisco: plantio-cultivo-botões-flor. A família não vive mais um silêncio amedrontador, não existe mais a comunicação silenciosa pelo olhar. No campo lexical do falar, não há mais verbos relacionados a um falar contido, como "sussurrar", “murmurar", "gaguejar". Há, ainda, palavras do campo semântico do silêncio, mas não se trata do mesmo "silêncio opressor". Como afirma Kambili na Tabela 37: 
Tabela 37: Silêncio libertador

\begin{tabular}{|l|l|}
\hline \multicolumn{1}{|c|}{ Purple hibiscus } & \multicolumn{1}{c|}{ Hibisco roxo } \\
\hline $\begin{array}{l}\text { Silence hangs over us, but it is a different } \\
\text { kind of silence, one that lets me breathe. (p. } \\
145)\end{array}$ & $\begin{array}{l}\text { O silêncio paira sobre nós, mas é um tipo } \\
\text { diferente de silêncio, um que me permite } \\
\text { respirar. (p. 148) }\end{array}$ \\
\hline
\end{tabular}

A liberdade ainda é experimental, como os hibiscos roxos plantados. Mãe e filha ainda estão no processo de assimilação dessa liberdade, e ainda há assuntos que não podem ser verbalizados, como se vê no trecho da Tabela 38 .

Tabela 38: Liberdade de falar (ainda em processo)

\begin{tabular}{|c|c|}
\hline Purple hibiscus & Hibisco roxo \\
\hline $\begin{array}{l}\text { There is so much more that Mama and I do } \\
\text { not talk about }[\ldots . .] \text { There is still so much that } \\
\text { we do not say with our voices, that we do not } \\
\text { turn into words. (p. } 141 \text { ) }\end{array}$ & $\begin{array}{l}\text { Há muitas outras coisas sobre as quais } \\
\text { Mama e eu não conversamos. [...] Ainda há } \\
\text { muito que não dizemos com nossas vozes, } \\
\text { que não transformamos em palavras. (p. 145) }\end{array}$ \\
\hline
\end{tabular}

Também entre os irmãos, que deixaram para trás a linguagem do olhar, o diálogo não é completamente aberto. Ainda há muito a ser conversado entre eles (Tabela 39).

Tabela 39: Liberdade de falar (ainda em processo)

\begin{tabular}{|l|l|}
\hline \multicolumn{1}{|c|}{ Purple hibiscus } & \multicolumn{1}{c|}{ Hibisco roxo } \\
\hline There is so much that is still silent between & $\begin{array}{l}\text { Há muita coisa que ainda é silêncio entre mim } \\
\text { Jaja and me. Perhaps we will talk more with } \\
\text { e Jaja. Talvez algum dia nos falemos mais, } \\
\text { time, or perhaps we never will be able to } \\
\text { ou talvez nunca sejamos capazes de dizer } \\
\text { that have to clothe things in words, things } \\
\text { tudo, de vestir as coisas com roupas, as } \\
\text { coisas que estão nuas há tanto tempo. (p. } \\
148)\end{array}$ \\
\hline
\end{tabular}

Jaja assumiu a autoria do envenenamento do pai a fim de proteger a verdadeira autora: Beatrice. Após a prisão de Jaja, a mãe mostra que está traumatizada, com o olhar vazio (Tabela 40).

Tabela 40: Olhar e falar indicando o trauma de Beatrice

\begin{tabular}{|l|l|}
\hline \multicolumn{1}{|c|}{ Purple hibiscos } & \multicolumn{1}{|c|}{ Hibisco roxo } \\
\hline $\begin{array}{l}\text { Most times, her answers are nods and } \\
\text { shakes of the head, and I wonder if she really }\end{array}$ & $\begin{array}{l}\text { Na maioria das vezes, ela só responde } \\
\text { assentindo ou balançando a cabeça e eu me }\end{array}$ \\
heard. I used to ask Sisi to talk to her, because & pergunto se escutou mesmo. Eu costumava \\
she would sit with Sisi in the living room & pedir que Sisi conversasse com Mama, porque \\
forlong hours, but she said Mama would not & ela ficava horas sentada na sala de estar com \\
reply to her, that Mama simply sat and & $\begin{array}{l}\text { Sisi. Mas Sisi contou que Mama não } \\
\text { stared. (p. 142) }\end{array}$ \\
& $\begin{array}{l}\text { respondia, que ela só olhava para o nada, em } \\
\text { silêncio. (p. 142) }\end{array}$ \\
\hline
\end{tabular}


Apesar de traumas e assuntos não permitidos, o livro termina com um tom otimista. Kambili e sua mãe estão felizes com a saída iminente de Jaja da prisão, em uma semana: Her voice is loud (p. 145), I can talk about the future now (p. 145), I am laughing (p. 146). Os verbos que encerram o livro estão todos no futuro, demonstrando planos de vida nova. Novas chuvas se preparam para cair, anunciando a renovação da natureza e da vida da mãe e dos filhos (Tabela 41).

Tabela 41: Verbos no futuro como sinal de esperança

\begin{tabular}{|c|c|}
\hline Purple hibiscos & Hibisco roxo \\
\hline $\begin{array}{l}\text { "We will take Jaja to Nsukka first, and then } \\
\text { we'll go to America to visit Aunty Ifeoma," I } \\
\text { say. "We'll plant new orange trees in Abba } \\
\text { when we come back, and Jaja will plant } \\
\text { purple hibiscus, too, and I'll plant ixora so } \\
\text { we can suck the juices of the flowers." [...] } \\
\text { Above, clouds like dyed cotton wool hang } \\
\text { low, so low I feel I can reach out and squeeze } \\
\text { themoisture from them. The new rains will } \\
\text { come down soon. (p. 146) }\end{array}$ & $\begin{array}{l}\text { - Vamos levar Jaja primeiro a Nsukka e } \\
\text { depois vamos aos Estados Unidos visitar tia } \\
\text { Ifeoma - digo. - Vamos plantar laranjeiras } \\
\text { novas em Abba quando voltarmos, e Jaja vai } \\
\text { plantar hibiscos roxos também, e eu vou } \\
\text { plantar ixoras para podermos sugar o suco } \\
\text { das flores. } \\
\text { [...] Lá em cima, nuvens que parecem algodão } \\
\text { tingido pairam bem baixas, tão baixas que } \\
\text { sinto que posso esticar o braço e espremer a } \\
\text { água delas. As novas chuvas vão cair em } \\
\text { breve. (p. 149) }\end{array}$ \\
\hline
\end{tabular}

\subsection{Igbo, inglês e o lugar de fala das mulheres}

Para compreender o contexto em que se passa a narrativa de Purple hibiscus, é importante conhecer o locus da enunciação, ou seja, o lugar onde se encontra o sujeito que fala. A história acontece em cidades no sudeste da Nigéria: Abba, Nsukka, Aokpe, que fazem parte da Igboland, onde a maior parte da população pertence à etnia Igbo. Pereira (2012) resume a história do local e sua colonização:

\footnotetext{
A Igboland, ou a região Igbo, numa tradução para o português, está localizada no sudeste da Nigéria, incluindo os estados de Abia, Ebonyin, Enugu, Imo e Anambra. Os Igbos compõem o terceiro grupo étnico do país, depois dos hauçás-fulani e dos iorubás. Sua região foi um dos últimos territórios nigerianos a receber os missionários britânicos, que se estabeleceram por lá entre 1885 e 1960 (PEREIRA, 2012, p. 30).
}

Atualmente, o idioma oficial da Nigéria é o inglês. A língua do colonizador é a utilizada na mídia, no sistema educacional, na legislação e em ambientes formais, sendo, por isso, considerada a língua de prestígio. Já o igbo é a língua vernácula, usada na rua, nos lares, e em situações informais, sobretudo na Igboland. Nessa região, como 
no restante do país, percebe-se a situação de diglossia. Segundo Gorovitz e Martinez ([s.d.]), trata-se de:

[...] um conceito da sociolinguística e da sociologia da linguagem que se refere à situação de coexistência de duas ou mais línguas, relacionadas ou não, ou de variedades de uma mesma língua, [...] no mesmo território geográfico, tendo um tratamento diferenciado pela comunidade de fala de acordo com as situações comunicativas (GOROVITZ; MARTINEZ, [s.d.; s.p.]).

Diferentemente do bilinguismo, que se refere a um indivíduo, a diglossia está relacionada a uma "organização sociolinguística" (GOROVITZ; MARTINEZ, [s.d.]). No ambiente de Purple hibiscus, igbo e inglês coexistem, mas em situações comunicativas distintas.

Na família de Eugene, que é um homem rico e influente, o uso de inglês é obrigatório. Principalmente quando estão com outras pessoas, como o padre inglês da igreja St. Agnes, a professora irlandesa de Kambili, e autoridades nigerianas e estrangeiras. O igbo é inferiorizado e proibido, inclusive dentro da igreja. Assim como a cultura tradicional daquela etnia, é menosprezado e permitido somente em situações específicas, como no momento do ofertório (Tabela 42).

Tabela 42: Descrição do ofertório

\begin{tabular}{|c|c|}
\hline Purple hibiscus & Hibisco roxo \\
\hline $\begin{array}{l}\text { Father Benedict had changed things in the } \\
\text { parish, such as insisting that the Credo and } \\
\text { kyrie be recited only in Latin; Igbo was not } \\
\text { acceptable. Also, hand clapping was to be } \\
\text { kept at a minimum, lest the solemnity of Mass } \\
\text { be compromised. But he allowed offertory } \\
\text { songs in Igbo; he called them native songs, } \\
\text { and when he said "native" his straightline } \\
\text { lips turned down at the corners to form an } \\
\text { inverted U. (p. 6) }\end{array}$ & $\begin{array}{l}\text { O padre Benedict mudara as coisas na } \\
\text { paróquia, insistindo, por exemplo, que o credo } \\
\text { e o kyrie fossem recitados apenas em latim; } \\
\text { igbo não era aceitável. Além disso, devia-se } \\
\text { bater palmas o mínimo possível, para que a } \\
\text { solenidade da missa não ficasse } \\
\text { comprometida. Mas ele permitia que } \\
\text { cantássemos músicas de ofertório em igbo; } \\
\text { chamava-as de músicas nativas, e quando } \\
\text { dizia "nativas" a linha reta de seus lábios } \\
\text { pendia nos cantos e formava um U } \\
\text { invertido. (p. 5) }\end{array}$ \\
\hline
\end{tabular}

Raras são as situações comunicativas em que Eugene fala igbo. Ele, geralmente, fala inglês, e, dependendo de quem seja seu interlocutor, chega a forçar um sotaque britânico para ter um prestígio ainda maior (Tabela 43). 
Tabela 43: Mudança do sotaque de Eugene

\begin{tabular}{|c|c|}
\hline & Hib \\
\hline $\begin{array}{l}\text { Papa changed his accent when he spoke, } \\
\text { sounding British, just as he did when he } \\
\text { spoke to Father Benedict. He was gracious, in } \\
\text { the eager-to-please way that he always } \\
\text { assumed with the religious, especially with } \\
\text { the white religious. (p. 26) }\end{array}$ & $\begin{array}{l}\text { Papa mudou de sotaque quando respondeu, } \\
\text { adotando uma pronúncia britânica, como } \\
\text { fazia quando falava com o padre Benedict. Ele } \\
\text { se mostrou gracioso e ansioso por agradar, } \\
\text { como sempre era com os religiosos, } \\
\text { principalmente os religiosos brancos. (p. 24) }\end{array}$ \\
\hline
\end{tabular}

Quando Eugene usa o igbo, expressa emoções intensas e primitivas, como a raiva. Por exemplo, na cena em que pune Kambili violentamente, após encontrar o retrato de Papa-Nnukwu, e quando questiona, logo no início do livro, a atitude de Jaja, de não responder ao seu questionamento. Eugene fala em igbo, o que a filha considera um mau sinal, de raiva e de descontrole (Tabela 44).

Tabela 44: Uso do igbo em momentos de raiva

\begin{tabular}{|c|c|}
\hline Purple hibiscus & Hibisco roxo \\
\hline $\begin{array}{l}\text { Papa was staring pointedly at Jaja. "Jaja, have } \\
\text { you not shared a drink with us, gbo? Have you } \\
\text { no words in your mouth?" he asked, entirely } \\
\text { in Igbo. A bad sign. He hardly spoke Igbo, } \\
\text { and although Jaja and I spoke it with } \\
\text { Mama at home, he did not like us to speak } \\
\text { it in public. We had to sound civilized in } \\
\text { public, he told us; we had to speak } \\
\text { English.(p. 10) }\end{array}$ & $\begin{array}{l}\text { Papa olhava fixamente para Jaja. } \\
\text { - Jaja, você não bebeu conosco, gbo? Não há } \\
\text { palavras em sua boca? - perguntou, falando } \\
\text { em igbo. Aquilo era um mau sinal. Papa } \\
\text { quase nunca falava em igbo e, embora Jaja } \\
\text { e eu usássemos a língua com Mama quando } \\
\text { estávamos em casa, ele não gostava que o } \\
\text { fizéssemos em público. Precisávamos ser } \\
\text { civilizados em público, ele nos dizia; } \\
\text { precisávamos falar inglês. (p. 10) }\end{array}$ \\
\hline
\end{tabular}

Gorovitz e Martínez ([s.d., s.p.]) explicam que "a diglossia funciona de acordo com o princípio de diferenciação linguística e de desigualdade social". Em Purple hibiscus, essa desigualdade se coloca, em um primeiro momento, no plano econômico e político, uma vez que, quanto mais poder e posses tiver o sujeito, mais distante ele estará das origens e da língua tradicional, a pré-colonial. Como consequência, o igbo se torna o que Ferguson (1959, apud GOROVITZ; MARTINEZ, [s.d., s.p.]) chama de uma "variedade baixa".

A língua materna fica, assim, em lugares desprestigiados e é usada por um grupo determinado, considerado inferior. O igbo é falado dentro dos lares, por pessoas tradicionalistas e, sobretudo, por mulheres, que são os sujeitos desses espaços e que, apesar de possuírem a competência linguística para falar inglês, optam pelo igbo quando a situação comunicativa lhes é confortável. 
Na casa de Ifeoma, mãe e filhos falam igbo, principalmente na presença do avô, Papa-Nwukwu - um ancião tradicionalista que não compreende a língua do colonizador; e orações e cânticos também são entoados em igbo. Na casa de Beatrice, apesar da repressão do marido, o igbo também tem seu lugar e é resgatado pelas mulheres na expressão de emoções, como no raro momento em que a mãe se permite cantar (Tabela 45).

Tabela 45: Beatice canta em igbo

\begin{tabular}{|l|l|}
\hline \multicolumn{1}{|c|}{ Purple hibiscus } & \multicolumn{1}{|c|}{ Hibisco roxo } \\
\hline She always waited by the front door on the & Ela sempre esperava na porta da frente no \\
last day of school, to sing praise songs in & último dia de aula, para cantar músicas de \\
Igbo and hug Jaja and me and caress our & agradecimento em igbo, me abraçar e \\
report cards in her hands. It was the only & abraçar Jaja e acariciar nossos boletins. Essa \\
time she sang aloud at home. & era a única ocasião em que Mama cantava \\
"O me mma, Chineke, o me mma..." Mama & em casa. \\
started her song and then stopped when I & - Orne mma, Chineke, o me mma... -cantou \\
greeted her. & $\begin{array}{l}\text { Mama interrompendo-se quando a a } \\
\text { "Good afternoon, Mama." (p. 22) }\end{array}$ \\
& cumprimentei. \\
\end{tabular}

Os vocativos também são marcas, ao longo do texto, do lugar social que o igbo ocupa: a língua doméstica, da intimidade. Os filhos se referem à mãe como Mama e ao pai como Papa, mesmo quando estão falando em inglês. $\mathrm{O}$ avô não colonizado é PapaNnukwu, enquanto o pai de Beatrice, que serviu aos missionários ingleses, quer ser chamado de Grandfather: "He had insisted that we call him Grandfather, in English, rather than Papa-Nnukwu or Nna-Ochie" (p. 36). ${ }^{41}$ Ifeoma sempre chama Beatrice de Nwunye $m$, expressão que lhe agrada, apesar de criticada por Eugene (Tabela 46).

Tabela 46: Tratamento entre Ifeoma e Beatrice

\begin{tabular}{|c|c|}
\hline Purple hibisc & Hibis \\
\hline $\begin{array}{l}\text { "Nwunye } m \text { ", Aunty Ifeoma called, and } \\
\text { Mama turned back. }\end{array}$ & $\begin{array}{l}\mathbf{m} \text { - chamou tia Ifeoma, e Mama s } \\
\text { lta. }\end{array}$ \\
\hline I heard Aunt & $\mathrm{N}$ \\
\hline $\operatorname{ars}$ ago, I v & Ma \\
\hline & \\
\hline & \\
\hline & \\
\hline & \\
\hline
\end{tabular}

\footnotetext{
41 "Insistira para que o chamássemos de Vovô em vez de Papa-Nnukwu ou Nna-Ochie." (p. 35) Ao traduzir "grandfather" como "vovô", ocorreu a perda desse importante marcador do inglês como língua de prestígio, adotada pelo colonizado.
} 
whispered, although we were alone in my room, "I am her wife, too, because I am your father's wife. It shows that she accepts me." (p. 38) que se casava. Mais tarde Mama sussurrara, apesar de estarmos sozinhas em meu quarto:

- Eu sou esposa dela também, pois sou esposa de seu pai. Isso mostra que ela me aceita. (p. 37)

Assim como o tratamento em igbo demonstra proximidade entre as cunhadas, o relacionamento entre as primas é selado quando Amaka, mostrando intimidade e amizade, passa a chamar Kambili de nwanne m nwanyi (Tabela 47).

Tabela 47: Tratamento entre Amaka e Kambili

\begin{tabular}{|l|l|}
\hline \multicolumn{1}{|c|}{ Purple hibiscus } & \multicolumn{1}{|c|}{ Hibisco roxo } \\
\hline "We will see you soon," Amaka whispered & - A gente se vê em breve - sussurrou Amaka \\
before we hugged good-bye. She called me & antes de nos abraçarmos. \\
nwanne $\boldsymbol{m}$ nwanyi - my sister. She stood & Ela me chamou de "nwanne m nwanyi" - \\
outside the flat, waving, until I could no & minha irmã. Ficou do lado de fora do \\
longer see her through the rear windscreen. (p. & $\begin{array}{l}\text { apartamento, acenando, até eu não conseguir } \\
\text { mais vê-la pelo retrovisor. (p. 126) }\end{array}$ \\
\hline 121$)$ &
\end{tabular}

O igbo é usado na forma oral de expressão, e essa oralidade remete à ancestralidade da língua, da cultura e a rituais. Quando Ifeoma, irritada com a oferta de Eugene de preparar um funeral católico para o pai, amaldiçoa o irmão, proferindo uma praga em igbo, ela resgata a tradição religiosa pré-colonial (Tabela 48).

Tabela 48: Feitiço em igbo

\begin{tabular}{|c|c|}
\hline Purple hibiscus & Hibisco roxo \\
\hline $\begin{array}{l}\text { "Was our father a Catholic? I ask you, } \\
\text { Eugene, was he a Catholic? Uchu gba gi!" } \\
\text { Aunty Ifeoma snapped her fingers at Papa; } \\
\text { she was throwing a curse at him.(p. 92) }\end{array}$ & $\begin{array}{l}\text { - [...] O nosso pai era católico? Estou lhe } \\
\text { perguntando, Eugene, ele era católico? Uchu } \\
\text { gba gi! } \\
\text { Tia Ifeoma estalou os dedos para Papa; ela } \\
\text { estava jogando uma maldição nele. (p. 95) }\end{array}$ \\
\hline
\end{tabular}

Ifeoma, personagem de personalidade feminista, é quem ousa reverter o padrão, tanto nas atitudes de sua vida (não tem marido, cria os filhos sozinha, questiona a função do casamento) quanto na esfera linguística. No contexto de diglossia, ela usa a língua materna, doméstica e inferiorizada - assim como a mulher naquela sociedade para confrontar o irmão, e discute com ele - em tom de igualdade, e não de submissão em igbo, mesmo quando ele fala em inglês (Tabela 49). 
Tabela 49: Confronto entre Ifeoma e Eugene

\begin{tabular}{|c|c|}
\hline Purple hibiscus & Hibisco roxo \\
\hline $\begin{array}{l}\text { Every time Aunty Ifeoma spoke to Papa, my } \\
\text { heart stopped, then started again in a hurry. It } \\
\text { was the flippant tone; she did not seem to } \\
\text { recognize that it was Papa, that he was } \\
\text { different, special. I wanted to reach out and } \\
\text { press her lips shut and get some of that shiny } \\
\text { bronze lipstick on my fingers. } \\
\text { "Where do you want to take them?" Papa } \\
\text { asked, standing by the door. } \\
\text { "Just to look around." } \\
\text { "Sightseeing?" Papa asked. He spoke } \\
\text { English, while Aunty Ifeoma spoke Igbo. (p. } \\
\text { 41) }\end{array}$ & $\begin{array}{l}\text { Toda vez que tia Ifeoma se dirigia a Papa, } \\
\text { meu coração parava e depois começava a } \\
\text { bater de novo, freneticamente. Era por causa } \\
\text { daquele tom atrevido; ela não parecia } \\
\text { reconhecer que aquele era Papa, que ele } \\
\text { era diferente, especial. Tive vontade de } \\
\text { apertar os lábios dela para fechá-los, e } \\
\text { também para pegar um pouco de batom cor de } \\
\text { bronze nos dedos. } \\
\text { - Para onde você quer levá-los? - perguntou } \\
\text { Papa, que estancara ao lado da porta. } \\
\text { - Para dar uma volta, só isso. } \\
\text { - Um passeio? - perguntou Papa, falando } \\
\text { inglês enquanto tia Ifeoma falava igbo. (p. } \\
\text { 40) }\end{array}$ \\
\hline
\end{tabular}

A ousadia de Ifeoma quebra a estratificação das línguas e dos papéis de homem e mulher. Ela leva o igbo para "fora da casa", do ambiente exclusivo das mulheres, e coloca as duas línguas em pé de igualdade. Para ela, não há uma língua socialmente privilegiada, assim como não deve haver um gênero privilegiado, que subjuga e exclui o outro.

A fala de Ifeoma pode ser interpretada como uma resposta à pergunta retórica de Spivak (2010): “pode o subalterno falar?" ou, nesse contexto, "pode a subalterna falar?”. Ifeoma tem sua própria consciência e não aceita ser representada na categoria da oprimida, do estereótipo de mulher que se submete à tradução cultural. Em seu discurso, ela tira sua posição como mulher e sua língua do lugar marginal e mostra orgulho em ser o que é.

A inserção de termos em igbo é uma característica recorrente na produção literária de Chimamanda, que também está presente na obra de Chinua Achebe, em quem se inspirou. Conforme explica Sommer (1994), a estratégia de manter trechos na língua ancestral em um texto escrito na língua do colonizador seria uma maneira de manter o distanciamento do leitor, limitando seu acesso à total significação do texto. Não é uma barreira a ser transposta, um desafio a ser vencido, mas um sinal para o leitor “outsider"- o forasteiro que quer se apossar e conquistar - não ultrapassar.

Nos textos dos dois autores, é permitido que o leitor compreenda alguns termos do igbo, mas, em outros momentos, a incompreensão, a incomunicabilidade e o silêncio permanecem intencionalmente. O silêncio que se instala, nesses trechos, é um alerta contra a homogeneização: “Os gestos ecumênicos para reduzir a alteridade para a 
igualdade sugerem que a diferença é um problema superável em vez de uma fonte de orgulho ou, simplesmente, a forma como somos no mundo"42 (SOMMER, 1994, p. 534). Por meio do registro de duas línguas, Achebe e Chimamanda denunciam as posições assimétricas de colonizado e colonizador e rejeitam essa proposta multicultural de coexistência hegemônica.

Anchieta (2014) elenca quatro estratégias de inserção do vocabulário igbo no romance Things fall apart (1958), de Achebe: tradução literal, repetição de termos ao longo do texto, paráfrase e contextual. As mesmas estratégias podem ser percebidas igualmente na fala dos personagens, em Purple hibiscus, e foram mantidas em Hibisco roxo.

A primeira estratégia elencada é a "tradução literal” do termo. O equivalente em inglês aparece após a palavra em igbo, seguida de palavras explicativas como or, called, ou pelo sinal de pontuação. Um exemplo é a explicação do título recebido por Eugene: Papa's title was omelora, after all, The One Who Does for the Community. ${ }^{43}$

A segunda estratégia é a "repetição de determinados termos no decorrer da obra, de tal forma que o leitor se familiarizasse com eles e compreendesse seus sentidos" (ANCHIETA, 2014, p. 40). A expressão nne, por exemplo, aparece 45 vezes em diálogos ao longo do texto, e pode ser entendida como um vocativo carinhoso para mulheres - como "querida"; na maioria das vezes, utilizado entre mães e filhas: "Nne, you're going to have a brother or a sister." 44

A terceira estratégia, "paráfrase", é aquela em que se "explica determinada situação antes de inserir o termo" (ANCHIETA, 2014, p. 41). Como bem assinalado por Anchieta (2014), evidências dessa estratégia são mais diluídas pela obra. Como na explicação da palavra Chukwu, na frase "This is what our people say to the High God, the Chukwu," Papa-Nnukwu said. ${ }^{45}$

A quarta estratégia, chamada de "contextual", "permite que o leitor compreenda o termo pelo contexto de determinadas situações da obra" (ANCHIETA, 2014, p. 41). Como exemplo, o significado do termo akwam ozu, que se refere ao ritual fúnebre de Papa-Nnukwu:

\footnotetext{
42 "The ecumenical gestures made to reduce otherness to sameness suggest that difference is a superable problem rather than a source of pride or simply the way we are in the world."

${ }^{43}$ Purple hibiscus, p. 30 / Afinal, o título de Papa era omelora, Aquele Que Faz pela Comunidade (Hibisco Roxo, p. 29, grifo meu).

${ }^{44}$ Purple hibiscus, p. 13 / - Nne, você vai ganhar um irmão ou uma irmã. (Hibisco roxo, p. 12, grifo meu).

${ }^{45}$ Purple hibiscus p. 43 / - Isso é o que dizemos para o Grande Deus, Chukwu - disse Papa Nnukwu (Hibisco roxo, p. 43, grifo meu).
} 
"You know Papa-Nnukwu's akwam ozu is next week?"

"Yes."

"We will wear white. Black is too depressing, especially that shade people wear to mourn, like burnt wood. I will lead the dance of the grandchildren." She sounded proud $^{46}$ (ADICHIE, 2004, p. 99, grifo meu).

A tradutora de Hibisco roxo manteve todos os termos em igbo de Purple hibiscus, mantendo a mesma grafia. Ao ser questionada sobre essa decisão, Júlia Romeu respondeu que não havia recebido da editora um glossário e que havia buscado na internet o significado de alguns termos, mas em nenhuma fonte oficial. Segundo ela, sua opção por manter os termos foi feita de forma consciente, com o intuito de preservar o estranhamento intencional da escritora. ${ }^{47}$ Embora não conhecesse o histórico da escritora e suas influências, a manutenção dos termos foi uma decisão acertada da tradutora, que conseguiu, assim, transmitir também ao leitor do português tanto o estranhamento como o conhecimento de vocabulários da cultura nigeriana.

${ }^{46}$ - Sabia que o akwam ozu de Papa-Nnukwu é na semana que vem?

- Sabia.

- Nós vamos nos vestir de branco. Preto é deprimente demais, principalmente aquele tom que as pessoas usam quando estão de luto, que parece cor de madeira queimada. Eu vou ser a primeira a fazer a dança dos netos - disse, parecendo orgulhosa.

47 "Não, não elaborei. Acredito que a Chimamanda, assim como muitos autores que falam línguas pouco conhecidas pelo grande público, deixou alguns termos em igbo sem tradução propositalmente, para causar uma estranheza no leitor com a presença deles ali. Na época, procurei a tradução de alguns por curiosidade e para melhor compreensão da obra como um todo, mas não tinha uma fonte confiável e não considerei a hipótese de incluir as traduções que encontrei na edição (resposta enviada por e-mail em 04 de janeiro de 2017). 


\section{CAPÍTULO 3: THE PIECES OF GODS: (RE)CONSTRUINDO SIGNIFICADOS}

\subsection{Feminismo, Feminismo Negro, Womanism, Africana Womanism: várias mulheres, várias lutas}

Ao narrar sua história e se apresentar ao público, Chimamanda descreve o embate por que passou ao se definir como feminista. A escritora utiliza a própria experiência para questionar o estereótipo de mulher feminista que ainda ocupa o imagético de grande parte das pessoas:

[...] Eu só queria ilustrar como a palavra "feminista" tem um peso negativo: a feminista odeia os homens, odeia sutiã, odeia a cultura africana, acha que as mulheres devem mandar nos homens; ela não se pinta, não se depila, está sempre zangada, não tem senso de humor, não usa desodorante (ADICHIE, 2015, p. 14-15).

Não há um conceito definido, unânime, para o feminismo. A luta pelas mulheres por uma posição de igualdade na sociedade tem diversas variações, assim como são diversas as necessidades e os tipos de exclusão e preconceitos sofridos, de acordo com a classe social, cor e região em que vivem. Também de acordo com o momento histórico, as fases - também denominadas "ondas" - do feminismo focaram em direitos específicos. ${ }^{48}$ Porém, isso não significa que as reivindicações da fase anterior tenham sido alcançadas, apenas que mudanças no contexto social tenham levado a ênfases diversas.

A primeira onda do chamado "movimento feminista" foi iniciada no século XIX, a partir do movimento sufragista, sobretudo em países da Europa e Estados Unidos. A luta era principalmente por direitos legais, como ao voto e à propriedade e melhoria das condições de trabalho e remuneração. O movimento sufragista foi considerado um movimento de mulheres brancas de classe média, pois não incluía as mulheres negras que, à época, sequer eram detentoras dos direitos básicos e continuaram sem direito ao voto.

Enquanto a primeira onda focava na igualdade jurídica e política entre homens e mulheres, o enfoque da segunda onda, iniciada na década de 1960, estava nas diferenças

\footnotetext{
${ }^{48}$ Como há vasta publicação acadêmica e da mídia acerca do Feminismo, da problematização, do conceito e mesmo do estabelecimento de ondas feministas, optei por me ater à sistematização apresentada sucintamente no livro $O$ que é feminismo, de Alves e Pitanguy (1985), de modo a localizar a vertente defendida pela escritora aqui pesquisada.
} 
entre ambos, no direito ao corpo, ao prazer sexual e aos direitos reprodutivos. Influenciada pela publicação de $O$ segundo sexo, de Simone de Beauvoir, em língua inglesa, passou a ser discutida a questão do "ser mulher" enquanto construto social, e ao questionamento de justificativas biológicas para desvalorização da mulher. É dessa época a diferenciação entre os conceitos de sexo (binário e definido genericamente: masculino e feminino), e gênero, definido social e culturalmente. Como explicam Alves e Pitanguy (1985):

\begin{abstract}
Simone de Beauvoir estuda a fundo o desenvolvimento psicológico da mulher e os condicionamentos que ela sofre durante o período de sua socialização, condicionamentos que, ao invés de integrá-la a seu sexo, tornam-na alienada, posto que é treinada para ser mero apêndice do homem. Para a autora, em nossa cultura, é o homem que se afirma através de sua identificação com seu sexo, e esta autoafirmação, que o transforma em sujeito, é feita sobre a sua oposição com o sexo feminino, transformado em objeto, e visto através do sujeito (ALVES; PITANGUY, 1985, p. 53).
\end{abstract}

A terceira onda do movimento feminista, iniciada a partir dos anos de 1980, tem sua questão centrada não mais na diferença entre homens e mulheres, mas nas desigualdades dentro da categoria "mulher". Nessa nova onda, são propostos recortes dentro dessa categoria, que não deve ser universalizada, sob o risco de se tornar excludente e apagar diferentes opressões sofridas por diferentes mulheres por cor, classe social, escolaridade, opção sexual, entre outros fatores.

Com o intuito de trazer maior visibilidade para a questão da opressão sofrida pela mulher negra, surgiram variedades do ativismo feminista. Dentre elas, destacamos o feminismo negro, o Womanism e o Africana Womanism.

O feminismo negro tornou-se popular na década de 1970 nos Estados Unidos, a partir da iniciativa de pensadoras como Audre Lorde e bell hooks, ${ }^{49}$ que criticavam o movimento feminista por não representar os anseios e as lutas das mulheres negras. Para essa corrente, preconceitos de gênero e cor estariam interligados e não poderiam ser combatidos separadamente.

O Womanism $^{50}$ foi um termo cunhado pela escritora Alice Walker, também na década de 1970. Tem abrangência mais ampla que o feminismo negro e uma proposta que, além de rejeitar a visão eurocêntrica feminista, abarca os homens negros, também

\footnotetext{
49 "bell hooks" é o pseudônimo de Gloria Jean Watkins, grafado sempre em minúsculas por opção da escritora.

${ }^{50}$ É possível encontrar textos em português sobre o mesmo tema utilizando a tradução mulherismo, enquanto outros usam o termo womanism. Nesta pesquisa, optei por manter a nomenclatura original womanism, que me pareceu mais abrangente.
} 
explorados e subjugados pelo patriarcado branco, e não se restringe somente a questões raciais e de gênero. Trata-se de uma proposta humanista de coletividade e igualdade racial, política, cultural e social. Como explica Veronesi (2015):

Definido por Walker, pela primeira vez no conto Coming Apart (1979), o "womanismo" é comumente usado na especificação do feminismo para mulheres negras. Entretanto, mais do que um movimento social, ele é, segundo Maparyan (2012), um movimento espiritual, comprometido com a sobrevivência e o bem-estar de todas as pessoas, independente de raça, sexo, religião, entre outros aspectos (VERONESI, 2015, p. 12).

A escritora e crítica nigeriana Chikwenye Okonjo Ogunyemi (1985) cunhou o termo Womanism africano, o qual não pode ser definido como uma corrente do feminismo, pois, apesar de ter algumas semelhanças iniciais, como a defesa da liberdade e da independência femininas, transcende a ideia de gênero e o conceito de patriarcado combatido pelas feministas brancas. Como explica Telega-Soares (2014),

[...] para Ogunyemi, o conceito do womanism subentende a consciência de que as questões de gênero não são e não podem ser separadas dos outros fatores e das outras realidades que, em conjunto, determinam a vida das mulheres no seu contexto familiar, local e comunitário. Só este contexto tem todo o sentido para as mulheres africanas e é aqui que elas divergem da compreensão do feminismo branco, muito focado nas questões de gênero e das relações de gênero privadas, muitas vezes, do seu contexto. A noção de raça ligada à classe e gênero, o trio abandonado pelas feministas marxistas, utilizada por Ogunyemi difere substancialmente da noção avançada por Alice Walker (TELEGA-SOARES, 2014, p. 39).

Em 1988, a professora Cleonora Hudson-Weems, da Universidade de Missouri, Estados Unidos, cunhou o termo Africana Womanism, inicialmente em palestras, e posteriormente publicando o livro Africana Womanism: reclaiming ourselves [Africana Womanism: resgatando a nós mesmas], em 1993. O termo Africana, na língua inglesa, refere-se a povos africanos no continente e nos outros países da diáspora africana (aqueles para onde foram levados, escravizados, ou para onde migraram) e seus descendentes em todo o mundo, tanto no continente americano como na Ásia e nas ilhas do Pacífico.

O Africana Womanism faz referência a todas as mulheres negras, africanas ou de ascendência africana, tanto as que vivem na África como as que estão "em diáspora”, ou seja, descendentes de africanas. É uma ideologia denominada "afrocêntrica", exclusiva para as mulheres negras, cujo enfoque está nas lutas, injustiças e experiências vividas 
por essas mulheres e no resgate das tradições e na história de seus antepassados africanos.

Há, atualmente, muitas outras ramificações de movimentos em prol da luta da mulher africana, como o Stiwanism, acrônimo de Social Transformation Including Women of Africa, Motherism, que valoriza o papel da mãe naquelas culturas, Negofeminismo, junção de duas palavras, "nego" - de negociação - e "feminismo", no qual "dominam os valores de compromisso - de dar e de receber - do equilíbrio e da harmonia" (TELEGA-SOARES, 2014, p. 45).

Igualmente, os movimentos se multiplicam em outras partes do mundo, buscando focar nas lutas de mulheres em regiões específicas, como o Mujerismo, pela liberação das mulheres hispânicas, e o Negralismo, pelo reconhecimento da mulher negra no Brasil. A conceitualização e a diferenciação dos ramos é imprecisa, assim como as teorias, ainda inconsistentes, em formação.

A ideologia apresentada por Chimamanda guarda várias semelhanças aos vieses africanos aqui apresentados, nos quais a luta por igualdade (e não pela supremacia feminina) valoriza a cultura e as origens da mulher (que têm opressões diferentes), além de defender que homens também têm um importante papel a desempenhar nessa conquista da liberdade. Acredito que a opção da escritora por utilizar o termo "feminismo" e se apresentar como "feminista" deve-se a certa amplitude do termo, que tem variadas interpretações e correntes e pode, assim, abarcar diferentes mulheres. $\mathrm{O}$ uso do termo "feminista" também fornece certa neutralidade, quando a escritora opta por utilizar a definição lexicográfica do dicionário. Como ela própria explica:

Ele tinha razão, anos atrás, ao me chamar de "feminista". Eu sou feminista. Naquele dia, quando cheguei em casa e procurei a palavra no dicionário, foi este o significado que encontrei: "Feminista: uma pessoa que acredita na igualdade social, política e econômica entre os sexos" (ADICHIE, 2015, p. 49).

Utilizando a definição, dessa forma, Chimamanda evita envolver-se em questões terminológicas polêmicas e consegue dar mais visibilidade ao assunto principal, que é a luta contra a desigualdade de gênero. 


\title{
3.2 A Tradução Feminista e o empoderamento da tradutora
}

Para compreender como se deu a convergência da proposta feminista com a prática tradutória, é importante vislumbrar as perspectivas histórica, política e social do fenômeno. Partindo-se da análise da evolução do papel da mulher dentro da literatura e da tradução, é possível perceber que a conquista do espaço próprio e da autonomia transcende o meramente literário e abarca, também, a conjuntura social, sobretudo quanto à questão de gênero.

Tradicionalmente, a tradução e a mulher têm papéis análogos, cabendo a ambas apenas a função secundária de reprodução. Segundo Simon (1996), na visão conservadora, o ato de criação seria exclusividade do autor e seria seguido de um ato passivo de transmissão: a tradução. Somente o texto de partida, o "original", conteria a verdadeira essência, o valor autêntico, "adâmico", como o personagem bíblico, criado diretamente do divino. À tradução, assim como à mulher, caberia somente o compromisso de fidelidade e submissão - ao texto de partida e ao homem -, esforçando-se ao máximo para manter-se invisível.

\begin{abstract}
Seu status "entre lugares" se reflete até no espaço físico dado aos seus nomes como autores de trabalhos traduzidos. Leitores íntimos com a história da literatura podem ser incapazes de citar o nome de um único tradutor. Isso porque, ao contrário do nome do autor, o nome do tradutor não tem nem significado nem função no mundo das letras. Ele não é usado nem para identificar nem para catalogar livros; apenas excepcionalmente considera-se que transmita alguma informação especial ao crítico ou ao leitor ${ }^{51}$ (SIMON, 1996, p. 60).
\end{abstract}

O ponto inicial de análise da ação da mulher-tradutora na literatura escolhido por Simon (1996) é o século XVI. Durante o Renascimento, sobretudo na Inglaterra, a tradução de textos religiosos era uma das únicas atividades intelectuais consideradas apropriadas às mulheres. Naquela época, não era dada à mulher a oportunidade de escrever sua própria obra e, nem mesmo em suas traduções, o nome da tradutora era registrado. Criar era um papel exclusivamente masculino, e a literatura, um campo cujo acesso era proibido às mulheres.

\footnotetext{
51 “Their 'in-between' status is reflected even in the physical space given to their name as the authors of translated works. Readers intimate with the history of literature might be unable to name a single translator. That is because, in contrast to the name of the author, the name of the translator has neither meaning nor function in the world of letters. It is used neither to identify nor to catalogue books; it is only exceptionally considered as conveying any particular information to the critic or reader."
} 
Os textos religiosos, que reiteravam a subserviência feminina e sua posição marginal na sociedade, foram, ironicamente, a porta por onde a mulher pôde adentrar o universo literário e a vida cultural da época, por meio da tradução:

\begin{abstract}
Em nome da palavra de Deus, as mulheres puderam e reivindicaram o seu direito de falar independentemente dos homens. Elas escreveram, traduziram e publicaram muitas obras religiosas. A religião provavelmente impediu muitas mulheres de escrever sobre assuntos seculares, já que a maior parte do material de autoria feminina neste período consiste de composições e traduções religiosas. Não obstante, a religião lhes deu uma voz legítima e uma oportunidade de serem ouvidas ${ }^{52}$ (Krontiris, 1992, apud SIMON, 1996, p. 46).
\end{abstract}

Simon apresenta Margaret Tyler como pioneira na manifestação da mulher no cenário literário. Tyler traduziu do espanhol o romance de cavalaria $A$ mirrour of princely deeds and knighthood [Um espelho de façanhas de príncipes e cavalaria], em 1578, cuja publicação em inglês continha, pela primeira vez, um prefácio escrito e assinado por uma mulher. Nele, a tradutora critica os valores do século XVI e a ideologia que marginalizava a mulher e a considerava incapaz de escrever com autenticidade. Pelo prefácio, a mulher ganhou voz, quando a tradutora defendeu abertamente o direito das mulheres de escrever, ler e traduzir textos que fossem para "além do divino".

Outra precursora, no século XVII, foi a escritora, dramaturga e tradutora inglesa Aphra Behn (1640-1689). Suas traduções atingiram grande prestígio e eram consideradas sofisticadas, sobretudo pelo denominado "desenvolvimento do original" (SIMON, 1996, p. 55) e pelo esforço criativo característico do seu trabalho. Ela expandia parágrafos para explicar ou tecer sua opinião sobre determinado acontecimento, parafraseava trechos e fazia alusão a aspectos da sociedade inglesa que desejava criticar.

Um exemplo interessante dessas intervenções, apresentado por Simon (1996, p. 57), é o último trabalho da tradutora: a tradução do latim do sexto volume da coleção Six Books of Plants, de Abraham Cowley. A versão de Behn é bem mais extensa (quase três quartos mais longa) que o original. De todas as intervenções que a tradutora faz no texto, a mais interessante é a inserção de sua marca de forma direta, com anotações nas

\footnotetext{
52 "In the name of the word of God, women could and did claim their right to speak independently from men. They wrote, translated, and published many religious works. Religion probably prevented many women from writing on secular subjects, as most female authored material in this period consists of religious compositions and translations. None the less, religion gave them a legitimate voice and an opportunity to be heard."
} 
margens das folhas com a nota the translatress in her own person speaks here, o que demonstra o tênue limite entre tradução e escrita criativa. A denominação com o sufixo feminino inglês -tress também tem a intenção de explicitar a marca da autoria feminina da tradução. Em vez de manter a denominação neutra translator, que tende a ser interpretada como um sujeito masculino, Behn faz questão de lembrar ao leitor que é a tradutora que fala.

No século seguinte, a francesa Madame de Staël (1766-1817) foi um ícone da mudança de perspectiva da tradução tradicional, escrevendo ensaios de suma importância sobre a Teoria da Tradução. Entre eles, De l'esprit des traductions [O espírito das traduções], de 1821, no qual valoriza a atividade da tradução, em especial em seu papel político. Sua visão liberal demonstra-se pela afirmação de que a circulação de ideias, por meio da tradução de literatura estrangeira, serviria para enriquecer o nacional, criar novas ideias e novas formas literárias. Para ela, não deveria ser imposto um modelo ao qual o texto estrangeiro deveria se adaptar na língua de chegada. Pelo contrário, essa deveria, sim, receber o novo e se enriquecer com ele.

No século XX, com o surgimento de novas correntes e influências, o espaço de criatividade da tradutora se expandiu para além dos paratextos - dos prefácios e notas onde ela explicitava sua opinião sobre autor e obra do texto de partida, seu processo tradutório e suas reflexões - e invadiu o próprio texto literário. Superando a dicotomia entre a tradução ética proposta pela teoria alemã, e a tradução bela, porém infiel, dos franceses, surge a proposta das escritoras e tradutoras feministas.

A influência das ideias feministas chegou à tradução a partir da década de 1960, sobretudo nos Estados Unidos e no Canadá. Na província canadense de Quebec, por uma convergência de fatores culturais, sociais e ideológicos do momento, esse movimento teve imensa repercussão e gerou novas abordagens para a tradução. Como explica Dépêche (2000):

Na cena do Quebec dos anos 70 assiste-se a uma convergência das aspirações nacionalistas da "revolução tranquila", da tomada de consciência social e política, do questionamento das instituições - inclusive a literária - da língua e da escrita. Este kairos, este momento propício e intensamente criativo é aquele no qual vai florescer a produção da Escola Canadense de Tradução, contexto literário e sociopolítico particular, onde a ideologia feminista penetra as tomadas de posição intelectuais (DÉPÊCHE, 2000, p. 171).

James (2011) explica que, nessa época, havia um movimento pela independência de Quebec do Canadá, que levou os cidadãos partidários dessa ideia a buscar uma 
cultura própria, que refletisse linguisticamente, socialmente e politicamente uma identidade sem influência externa, rejeitando o imperialismo francês e o inglês. Essa busca de identidade e de descolonização se assemelha à proposta do movimento feminista, de tornar o feminino independente, com valor próprio e dissociado do masculino, numa proposta livre da visão androcêntrica predominante.

Para as feministas, a própria língua seria um espaço de subordinação da mulher pelo homem, um instrumento de opressão ao qual seria necessário reagir. Uma dessas reações foi a proliferação do que James (2011) chama de "escrita feminista experimental", no Canadá. Por meio de experimentações literárias e linguísticas divulgadas em palestras, encontros feministas e leituras públicas, procurava-se produzir um trabalho que retratasse o mundo sob a perspectiva da mulher, fora do malestream, da visão masculina dominante. Quebec foi a primeira região de língua francesa onde as escritoras, autodenominadas authers, passaram a proceder a esse processo de feminilização do idioma, dando origem ao denominado "grupo de Quebec".

A tradução desempenha um papel importante neste trabalho, pois, sendo o Canadá um país bilíngue e multicultural, essa nova forma de linguagem não patriarcal teria de ser divulgada em mais de uma língua. Para isso, seriam necessárias estratégias específicas de transmissão, para outra língua, que permitissem, igualmente, manipular o texto, negar e desconstruir a linguagem patriarcal e feminilizar a língua, para que se torne uma arma em prol da visibilidade das mulheres.

Barbara Godard (1942-2010) é uma das primeiras representantes do movimento de Tradução Feminista canadense. Juntamente com Susanne de Lotbinière-Harwood, traduziu obras da escritora feminista Nicole Brossard, cuja escrita, experimental, era repleta de metáforas, neologismos e jogos de palavras. Elas denominaram essa proposta de tradução de réécriture au feminin (reescrita no feminino), iniciando as primeiras discussões teóricas sobre gênero e tradução. As tradutoras passaram a desenvolver métodos que se assemelhavam aos dos textos de partida e deixavam espaço para a liberdade e a criatividade das tradutoras. Nas palavras de Lotbinière-Harwood, citada por Von Flotow (1997):

Réécriture au feminin (reescrita no feminino) é um ato consciente que coloca as cartas na mesa desde o início. Seu projeto é inserir na prática da tradução a consciência feminista [...] A tradução, assim, se torna uma atividade política 
que tem o objetivo de tornar as mulheres visíveis e presentes na língua e na sociedade $^{53}$ (Lotbinière-Harwood, apud VON FLOTTOW, 1997, p. 36).

Assim como tradutoras de épocas anteriores, Godard recorre ao prefácio para estabelecer um diálogo com o leitor e explicar as dificuldades e desafios de traduzir para o inglês a obra escrita em francês - sem que as marcações de gênero se perdessem - e as liberdades e licenças que tomou, ao longo de sua tradução. Ela denomina sua prática de transformance, da união das palavras transformation e performance.

Luise von Flotow, outra representante do grupo feminista de Quebec, menciona três das estratégias utilizadas pela Tradução Feminista nessa manipulação textual (VON FLOTOW, 1991, p.74). A primeira, supplementing, que pode ser entendida como suplementação ou sobretradução, quando o texto traduzido é suplementado, desenvolvido, e tem ideias e passagens acrescentadas pela tradutora. A segunda, prefácio e notas de rodapé (prefacing and footnoting), para reforçar a presença ativa no texto, ao contrário da visão ultrapassada da tradutora que prezava pela invisibilidade e buscava produzir uma versão agradável na língua de chegada. A terceira estratégia, denominada por Von Flotow de hijacking, refere-se à apropriação do texto, da livre intervenção e até mesmo correção do texto original, para chegar ao objetivo desejado pela tradutora, sem ressalvas ou limites para as alterações.

Em seu artigo, Von Flotow usa como exemplo dessa apropriação do texto e da livre intervenção da tradutora o prefácio de Susanne Lotbinière-Harwood à sua tradução de Lettres d'une autre, da escritora Lise Gauvin:

Lise Gauvin é feminista, e eu também sou. Mas eu não sou ela. Ela escreveu no genérico masculino. Minha prática de tradução é uma atividade política que visa a fazer a língua falar pelas mulheres. Portanto, minha assinatura numa tradução significa: esta tradução utilizou todas as estratégias possíveis de tradução para tornar o feminino visível na língua. Porque tornar o feminino visível na língua significa fazer com que as mulheres sejam vistas e ouvidas no mundo real. E isto é o feminismo ${ }^{54}$ (Lotbinière-Harwood, 1989, p. 9, apud VON FLOTOW, 1997, p. 29).

\footnotetext{
53 "Réécriture au feminin (rewriting in the feminine) is a conscious act that puts its cards on the table from the very beginning. Its project is to imbue translation praxis with feminist consciousness [...] translation thus becomes a political activity that has the objective of making women visible and resident in language and society."

54 "Lise Gauvin is a feminist, and so am I. But I am not her. My translation practice is a political activity aimed at making language speak for women. So my signature on a translation means: this translation has used every possible feminist translation strategy to make the feminine visible in language. Because making the feminine visible in language means making women seen and heard in the real world. Which is what feminism is all about."
} 
As palavras de Lotbinière-Harwood demonstram que, para esse círculo feminista, a tradução é vista como uma operação criativa que não tem compromisso com a fidelidade ao original. A ética e a fidelidade estariam relacionadas à causa feminista e ao propósito de revelação subjetiva. A tradutora tem a liberdade de intervir no texto, desde que mantenha seu foco no ato de destacar a mulher, o feminino e questionar paradigmas sociais, culturais e políticos - daí o termo womanhandling. Ou seja, a tradutora já não se sujeita à autoridade do autor nem à do texto original. Contrariando o adágio do século XVII, a tradutora feminista é definida por LotbinièreHarwood como Re-belle et Infidèle. Ela subverte a visão tradicional e se torna é cocriadora: é sujeito do ato da escrita, tão importante quanto o autor.

A tradutora modesta, recatada, que produz uma versão graciosa, de fácil
leitura na língua alvo, se tornou uma coisa do passado. Como afirma Godard
(1988, p. 50), a tradutora feminista busca ostentar sua assinatura em itálico,
notas de rodapé, e em prefácios, manipulando intencionalmente o texto e
participando ativamente na criação do significado ${ }^{55}$ (VON FLOTOW, 1991,
p. 76).

E é por meio dessa liberdade de criação e experimentação que o papel coadjuvante da mulher também é desmistificado. Assim, a mulher conquista cada vez mais visibilidade, não apenas no cenário político-social, mas também na literatura, ao apoderar-se do texto não mais para reproduzi-lo em outra língua, mas para produzir o seu próprio texto, com sua própria linguagem e explicitando sua própria visão de mundo.

No caso específico de Purple hibiscus, que é, originalmente, uma obra de temática feminista escrita por uma escritora feminista, a história tornou-se o que Von Flotow (1997, p. 43) denomina de "tradução monossêmica", e, em diversos momentos, é perceptível o empobrecimento, o "achatamento" do texto. A tradutora de Hibisco roxo realizou uma tradução literal, o mais próxima possível da letra do texto de partida, e suas escolhas tradutórias objetivas produziram um texto de fácil leitura, mas que gerou um texto de significado superficial, perdendo a profundidade do projeto literário da escritora.

\footnotetext{
55 "The modest, self-effacing translator, who produces a smooth, readable target language version of the original has become a thing of the past. As Godard has put it, the feminist translator seeks to flaunt her signature in italics, in footnotes, and in prefaces, deliberately womanhandling the text and actively participating in the creation of meaning."
} 
Um exemplo desse "achatamento" está no trecho em que Beatrice volta do hospital, dois dias após ter sido punida pelo marido com uma surra que provocou um aborto (Tabela 50).

Tabela 50: Fala de Beatrice após o aborto

\begin{tabular}{|l|l|}
\hline \multicolumn{1}{|c|}{ Purple hibiscus } & \multicolumn{1}{|c|}{ Hibisco roxo } \\
\hline $\begin{array}{l}\text { Her eyes were vacant, like the eyes of those } \\
\text { mad people who wandered around the } \\
\text { roadside garbage dumps in town, pulling } \\
\text { grimy, torn canvas bags with their life } \\
\text { fragments inside. }\end{array}$ & $\begin{array}{l}\text { Os olhos de Mama estavam sem expressão, } \\
\text { como os olhos daqueles loucos que vagueiam } \\
\text { "There was an accident, the baby is gone," } \\
\text { cidade, arrastando bolsas de lona imundas e } \\
\text { she said. (p. 20) }\end{array}$ \\
$\begin{array}{l}\text { rasgadas com os fragmentos de suas vidas } \\
\text { guardados dentro. } \\
\text { - Eu sofri um acidente e o bebê se foi - } \\
\text { disse ela. (p. 19) }\end{array}$ \\
\hline
\end{tabular}

A frase em que a mãe explica aos filhos o que aconteceu com ela e com o bebê, embora simples, é uma frase que carrega muito significado. No texto de partida, a personagem não usa a primeira pessoa, e o foco da primeira parte da frase é a palavra accident. Os filhos sabem o que ocorreu: não foi um acidente que fez com que Beatrice fosse ferida. Na expressão "eu sofri”, o uso da voz ativa reduz a carga dramática, a marca de Beatrice como vítima, como paciente da ação provocada intencionalmente pelo marido violento.

$\mathrm{Na}$ segunda parte, the baby is gone, a expressão registra o fim, um acontecimento sem volta, a morte. Em português, dizer "o bebê se foi" não traz esse significado marcante. Essa notícia tão importante e tão chocante para os filhos teria que ser dada com palavras impactantes em português, como "o bebê morreu” ou "o bebê está morto."

Retomando as estratégias sugeridas por Von Flotow (1991), apresento, a seguir, alguns trechos de Purple hibiscus que seriam mais bem explorados se a Tradução Feminista consciente tivesse sido aplicada.

Um exemplo de trecho em que a estratégia supplementing enriqueceria o texto é o momento de discussão entre Amaka e Ifeoma sobre a escolha do nome de crisma. A adolescente recusa-se e questiona a obrigação de adotar um nome em inglês para participar do ritual (Tabela 51). 
Tabela 51: Confronto entre mãe e filha

\begin{tabular}{|c|c|}
\hline Purl & Hibise \\
\hline $\begin{array}{l}\text { But Amaka refused. "Ekwero } \\
\text { Aunty Ifeoma- I do not a } \\
\text { walked into her room and tu } \\
\text { on very louduntil Aunty If } \\
\text { on the door and shouted th }\end{array}$ & $\begin{array}{l}\text { ela a tia Ifeoma - "Eu não concordo." Ela } \\
\text { então entrou no quarto e colocou uma } \\
\text { música bem alta, até que tia Ifeoma bateu } \\
\text { na porta e gritou que Amaka ia levar um } \\
\text { tapa se não abaixasse o volume naquele } \\
\text { instante. Amaka abaixou o volume. O padre } \\
\text { Amadi foi embora com um sorriso meio } \\
\text { confuso no rosto. (p. 135). }\end{array}$ \\
\hline
\end{tabular}

Uma "sobretradução" do trecho em destaque, desenvolvendo a fala de Amaka e sua expressão de revolta, seria muito mais significativa que a frase "eu não concordo", que é muito contida. Uma possível suplementação seria: "Mas Amaka se recusou. Ela gritou: 'Ekwerom! Eu me recuso! Não vou mudar meu nome!’, entrou no seu quarto, bateu a porta com força e ligou o som no volume máximo. Tia Ifeoma foi até lá, bateu na porta e disse, gritando: 'Amaka, se você não abaixar o volume imediatamente, você vai apanhar!"

A inserção de prefácio e notas - prefacing and footnoting - também é uma estratégia que seria capaz de aprimorar a leitura e a recepção de Hibisco roxo. Com a oportunidade de "conversar" com o leitor, explicar seu processo tradutório, apresentar a autora, a obra e o contexto histórico-cultural, além de suas impressões feministas, tanto antes quanto durante a história, a tradutora se mostraria ativa e criativa e poderia produzir um texto mais rico.

Com o trecho a seguir, Tabela 52, exemplifico essa afirmação.

Tabela 52: Poligamia na cultura Igbo

\begin{tabular}{|l|l|}
\hline \multicolumn{1}{|c|}{ Purple hibiscos } & \multicolumn{1}{c|}{ Hibisco roxo } \\
\hline $\begin{array}{l}\text { "God is faithful. You know after you came } \\
\text { and I had the miscarriages, the villagers } \\
\text { started to whisper. The members of our } \\
\text { umunna even sent people to your father to }\end{array}$ & $\begin{array}{l}\text { - Deus é fiel. Depois que você nasceu e eu } \\
\text { sofri aqueles abortos, o povo da vila começou } \\
\text { urge him to have children with someone } \\
\text { mandaram pessoas para falar com seu pai e } \\
\text { else. So many people had willing daughters, } \\
\text { and many of them were university graduates, }\end{array}$ \\
$\begin{array}{l}\text { insir que ele tivesse filhos com outra } \\
\text { too. They might have borne many sons and Tantos tinham filhas disponíveis, } \\
\text { taken over our home and driven us out, like } \\
\text { Mr. Ezendu's second wife did. But your father } \\
\text { stayed with me, with us." (p. 13) }\end{array}$ & $\begin{array}{l}\text { tudo. Elas poderiam ter parido muitos } \\
\text { filhos, tomado conta da nossa casa e nos } \\
\text { expulsado, como a segunda esposa do senhor } \\
\text { Ezendu fez. Mas seu pai ficou comigo, ficou } \\
\text { conosco. (p. 12) }\end{array}$ \\
\hline
\end{tabular}


O discurso ilustra uma característica cultural nigeriana e igbo: a poligamia. A inserção de uma nota sobre o assunto, explicando o contexto, a visão social local da prática, o significado do status social que tem um homem com várias esposas e a posição da primeira esposa nesses casamentos múltiplos, enriqueceria muito a compreensão da leitura no Brasil. A importância do casamento para a família da mulher, a obrigação de gerar filhos, principalmente do sexo masculino, e o fardo de uma mulher infértil, também poderiam ser comentados em notas da tradutora, tanto ao longo do texto como previamente, no prefácio. Sobretudo em uma tradução feminista militante, os comentários poderiam adquirir um tom crítico e questionador dessas práticas.

A última estratégia tradutória apresentada por Von Flotow - hijacking - é a mais ousada delas. Essa livre intervenção no texto original só seria possível em uma reescrita experimental e com um alerta claro para o leitor de que aquele texto estaria sendo alterado intencionalmente pela tradutora.

\subsection{Translatress, translatrix, translator: problematizando o masculino generalizante}

A visão de mundo predominante, patriarcal e sexista, está presente no uso que se faz da língua. Para a teoria feminista, ela é um produto social que serve para a manutenção dos papéis de gênero, que desprezam e apagam a mulher. Apesar de, pelo senso comum, a padronização do uso do masculino parecer natural, ela é um construto convencionado com o intuito de destacar o masculino e colocá-lo no topo da hierarquia social e política. Assim, a língua colabora para que a história do mundo, na qual a mulher é coadjuvante, seja o que as feministas denominam de his-story. Consequentemente, a proposta de tradução feminista - a ação da translatress ou da translatrix - é considerada subversiva, por sugerir outra posição para a mulher e para a tradução e o fim da hegemonia masculina, o que significaria uma "castração" do original. Como explica Chamberlain (1988):

Gostaria ainda de argumentar que a razão pela qual a tradução é tão controlada, tão regulada, é que ela ameaça apagar a diferença entre produção e reprodução, que é essencial para a hierarquia do poder. [...] Isso é, então, o que um crítico chama de manque inevitable: o que o original corre o risco de perder, em suma, é seu falo, sinal de paternidade, autoridade e originalidade ${ }^{56}$ (CHAMBERLAIN, 1988, p. 14, grifo do original).

\footnotetext{
56 "I would further argue that the reason translation is so overcoded, so overregulated, is that it threatens to erase the difference between production and reproduction which is essential to the establishment of
} 
Von Flotow (1997) apresenta duas abordagens diferentes para a questão da manipulação da linguagem convencional: a "radical" e a "reformista". A primeira vê a língua como a causa da opressão, que teria que ser desmontada e recriada para acolher o feminino. Já a "reformista" vê a língua como um sintoma da sociedade, que seria passível de reforma. Algumas dessas tentativas de reformas já vêm sendo realizadas com o intuito de incluir o feminino e combater o machismo da língua padrão.

Em 1987, a Organização das Nações Unidas para a Educação, a Ciência e a Cultura (UNESCO) publicou um manual de estilo e redação intitulado Guidelines on Gender-Neutral Language. ${ }^{57}$ Como parte da missão da Organização de "buscar transformar o comportamento e as atitudes que legitimam e perpetuam a exclusão social e moral das mulheres" (p. 3), apresenta definições de termos relacionados à luta pela igualdade das mulheres e uma lista de termos a serem evitados de forma a prevenir interpretações dúbias ou preconceituosas, além de sugestões para substituí-los e bibliografia sobre o tema.

Como exemplos para o inglês, podemos citar: a substituição da palavra men por human being ou humanity, quando se referir a ambos os sexos; o uso de s/he ou do plural, em vez da generalização no masculino (como na frase When a client needs assistance, he should contact the front desk, a forma s/he deve ser preferida, ou a colocação da frase completa no plural When clients need assistance, they should contact the front desk); a substituição da partícula -man em profissões, como fireman, policeman, craftsman, que podem ser reescritas como firefighter, police officer e craftworker.

Após a iniciativa da UNESCO, diversos órgãos elaboraram e adotaram manuais de redação para uso não sexista da língua, inclusive no Brasil: redes feministas e de direitos humanos, organizações jornalísticas e órgãos governamentais.

Outra iniciativa recente para dar representatividade e visibilidade às mulheres na língua no Brasil foi a criação da lei federal $n^{0} 12.605$, de 3 de abril de 2012, a qual determina o emprego obrigatório da flexão de gênero para nomear profissão ou grau em diplomas. Alvo de diversas críticas, principalmente pelos meios de comunicação, a lei, na verdade, não cria neologismos, como se aventou na imprensa e nas redes sociais à

power. [...] This, then, is what one critic calls the manque inevitable: what the original risks losing, in short, is its phallus, the sign of paternity, authority, and originality."

${ }^{57}$ Disponível em: <http://unesdoc.unesco.org/images/0011/001149/114950mo.pdf>. 
época. Ao contrário, ela torna obrigatório o uso de formas já existentes e gramaticalmente aceitas na língua portuguesa (como mestra e doutora) que eram camufladas pela generalização no masculino. Esse mesmo tipo de crítica, em defesa da objetivação e da neutralidade, também foi direcionado à proposta de Tradução Feminista.

O primeiro grupo de críticos contrários à abordagem feminista para a tradução, apresentado por Von Flotow (1997), era o daqueles avessos aos ideais feministas como um todo. Para eles, a proposta de Tradução Feminista poderia ser considerada subjetiva, emotiva e pouco acadêmica, carecendo de objetividade nos seus pressupostos. É o grupo mais conservador, que se opõe a reformas na língua e defende que o gênero (igualado, por eles, ao conceito de sexo) faria parte da língua e jamais poderia ser neutro ou apagado da língua.

O segundo grupo de críticas à proposta é o das pessoas que se identificam com os ideais feministas. A primeira crítica que Von Flotow (1997) apresenta é ao ar vanguardista e elitista da proposta de escrita experimental. Para esse grupo, uma proposta inovadora estaria direcionada a um seleto grupo de intelectuais, com conhecimento bilíngue e bicultural, e não traria efeitos concretos na esfera social e política. Assim, se tornaria uma proposta excludente que não abarcaria variadas culturas e tipos de escritas de mulheres.

Uma das mais ferrenhas críticas a essa proposta é a brasileira Rosemary Arrojo. Para ela, manipular um texto originariamente experimental é oportunista, pois a própria estrutura do texto já permite o descortinar de interpretações variadas e contém essa manipulação da língua em si. Outro ponto que Arrojo (1995) critica é a "violência" que as tradutoras aplicam nas suas intervenções ao texto, ao se apropriarem do texto, ao mesmo tempo em que criticam a agressividade de críticos masculinos. A aplicação estratégica da teoria desconstrutiva também é criticada por Arrojo (1995). Para ela, o significado é reconstruído e recriado continuamente, e uma proposta de criação de significado independente, inaugural, é inalcançável:

Como tenho proposto, a grande contribuição que as teorias de linguagem contemporâneas (vinculadas ao pós-modernismo e ao pós-estruturalismo) podem oferecer à reflexão sobre a tarefa da tradutora, ou do tradutor, é exatamente a noção de que toda tradução - como todo ato interpretativo - por se constituir inevitavelmente numa forma de re-escritura, numa interferência eminentemente autoral, será também, "violenta", ou seja, implicitamente se apoderará da escritura de outrém e sobre ela imporá seus próprios 
significados, ainda que tenha como única meta a proteção ao chamado "original" (ARROJO, 1995, p. 1).

Gayatri Spivak é outra crítica dessa proposta, sobretudo quanto à tradução de literatura produzida por mulheres de países de independência mais recente, do "terceiro mundo". Segundo Von Flotow (1997, p. 84), para Spivak (2010), o perigo seria a homogeneização da literatura produzida no Oriente, a interpretação ingênua da literatura do Terceiro Mundo como realismo, e a boa vontade da tradução para entender e disseminar a cultura e a literatura das mulheres do Terceiro Mundo e, assim, falar por elas.

\subsection{A invisibilidade da tradutora no mercado editorial}

Apesar da proposta de valorização e reconhecimento da importância do trabalho do sujeito-tradutor, ainda permanece, no mercado editorial atual, a cultura de tornar o tradutor (ou a tradutora) o menos visível possível na obra. A menos que se trate de um nome de peso, de um escritor ou escritora de renome fazendo a tradução da obra, a intenção da maioria das editoras é transmitir ao público consumidor a sensação de estar lendo a obra original.

No caso de Hibisco roxo, não há espaço de fala da tradutora em forma de paratextos, menos ainda liberdade para trabalhar no corpo do texto. Na página 104 do livro, está inserida a única nota da tradutora em todo o livro: a explicação sobre a frase "Chima e Obiora se deitaram no tapete e começaram a brincar com o baralho de whot* que Obiora havia achado em seu bolso". Diz a nota: “* jogo de baralho parecido com mau-mau (N.T.).” Como o jogo era uma informação secundária, que poderia passar sem o conhecimento detalhado pelo leitor (bastando a palavra "baralho" no corpo do texto), a nota pode ser considerada dispensável.

Além de não haver prefácios ou notas, o nome da tradutora não aparece na capa nem na lombada do livro. Essa invisibilidade intencional pode ser percebida nas instruções do Manual de redação e estilo da Cia. das Letras (2012).

No capítulo dois do Manual, estão listadas as orientações ao tradutor. Ali, podese ver o alerta para que o tradutor evite ao máximo a inserção de notas de rodapé: "2.2.3 Atenção: A não ser que se esteja elaborando uma edição anotada, evite o excesso de notas. Anote só o que for estritamente necessário para a compreensão do leitor médio.” 
Além de problematizar quem seria o "leitor médio", entidade indefinida e indefinível, pode-se ver, nessa nota, a intenção clara de fazer uma tradução transparente - o que é impossível, como discutido anteriormente.

A tradutora de Hibisco roxo, Júlia Romeu, tem formação em Jornalismo e mestrado em Literaturas de Língua Inglesa, e trabalha como free-lance para a editora Companhia das Letras. Também traduziu Americanah, o mais recente romance de Chimamanda, pela mesma editora. Por meio de correio eletrônico, a tradutora respondeu a perguntas sobre seu projeto de tradução.

Em um trecho da entrevista, podem-se observar alguns dos entraves que se colocam à criatividade e à liberdade da tradutora ao realizar uma tradução comercial, como escassez de tempo para realizar pesquisa prévia sobre o autor, a obra e seu contexto histórico, além de normas editorias impostas pela Editora.

E - Como você foi designada para ser a tradutora da obra? ${ }^{58}$

JR - Eu já tinha feito algumas traduções para a Companhia das Letras e alguém me chamou para fazer o Purple hibiscus. Não conhecia a obra da Chimamanda e, realmente, não sei por que me escolheram.

E - O que você sabia sobre a autora/sobre o livro anteriormente?

JR - Nada! A Chimamanda era muito menos conhecida naquela época. Fui pesquisar depois que me pediram para fazer o livro.

E - Half of a yellow sun foi o segundo romance de Chimamanda Adichie, mas o primeiro a ser traduzido no Brasil. Você já havia lido essa obra antes de Purple hibiscus? (Se sim, em português ou inglês?)

JR - Antes de traduzir o Purple hibiscus, comprei e li o original de Half a yellow sun e dei uma pesquisada na tradução para português, embora não tenha lido inteira.

E - Antes ou durante a tradução de Purple hibiscus, você fez algum tipo de pesquisa sociológica, cultural, geopolítica, histórica, etc. sobre a Nigéria?

JR - Sim, entrei em vários blogs sobre a Nigéria para aprender sobre a história, a geografia, a cultura do Brasil e a cultura igbo, à qual pertencem a autora e seus personagens no livro.

E - Quanto tempo você levou para traduzir o livro? Qual o prazo dado pela editora? Você considera que foi suficiente?

JR - Não me lembro exatamente. Em geral, tenho cerca de cinco meses para traduzir um livro. Considero que foi suficiente, sim.

\footnotetext{
${ }^{58}$ Entrevista realizada em 19 de outubro de 2015 por correio eletrônico. (E - entrevistador JR - Júlia Romeu)
} 
E - Por que não há prefácio ou introdução no início do livro, nem notas do tradutor ao longo do romance, ou outros paratextos em Hibisco roxo? Foi uma opção sua ou da editora?

JR - Foi uma opção da editora. A Companhia das Letras tem como regra não colocar notas do tradutor em obras de ficção. É claro que existem exceções, mas eles pedem que nós evitemos ao máximo.

A entrevista com Júlia Romeu ajudou a compreender o processo que levou à produção de um texto "achatado", simplificado. Apesar de a tradutora se considerar feminista e de ter afinidade com a tradução de literatura de autoria feminina, Hibisco roxo não pode ser considerado uma "tradução feminista". Embora em alguns momentos ela tenha produzido, de forma instintiva, uma tradução mais "livre" da letra do texto de partida, o significado e as marcas feministas não aparecem no texto de chegada com a mesma intensidade.

As exigências da editora se mostraram entraves para a criatividade e a liberdade do processo tradutório. As regras de edição, o tempo escasso, a falta de uma pesquisa mais abrangente da tradutora sobre a literatura nigeriana e sobre Chimamanda e a ausência de notas e prefácio se mostraram limitadores para um produto final sem "achatamentos". 


\section{CAPÍTULO 4: A DIFFERENT SILENCE - THE PRESENT: CONSIDERAÇÕES FINAIS}

Desde a iniciativa de escrita experimental no Canadá, muitos avanços ocorreram no campo dos Estudos da Tradução quanto às abordagens das questões relacionadas ao movimento feminista. O campo de pesquisa, que partiu do que Von Flotow (2009) descreve como do "microcosmopolita" - um contexto específico dentro do momento político e cultural em Quebec - para o "macrocosmopolita" - com a proposta local atingindo aplicação global -, ampliou-se e modificou-se. Para além da luta pela identidade da tradução, combatendo "metáforas misóginas" como a polaridade beleza versus fidelidade, a "paternidade do texto" e a invisibilidade da mulher, o alcance da Tradução Feminista tem se estendido e diversificado suas áreas de atuação.

Um dos fatores que contribuíram para essa diversificação e para a ampliação do foco foi o conceito de "interseccionalidade", cunhado pela norte-americana Kimberlé Crenshaw, em 1989. A proposta da interseccionalidade, de particularizar a análise de um sujeito ou grupo, considerando os fatores sociais, históricos, culturais, religiosos, econômicos, entre outros, tem influenciado o movimento feminista - e, consequentemente, os estudos da Tradução Feminista -, mudando, sobretudo, a abordagem de gênero:

\footnotetext{
A interseccionalidade é uma conceituação do problema que busca capturar as consequências estruturais e dinâmicas da interação entre dois ou mais eixos da subordinação. Ela trata especificamente da forma pela qual o racismo, o patriarcalismo, a opressão de classe e outros sistemas discriminatórios criam desigualdades básicas que estruturam as posições relativas de mulheres, raças, etnias, classes e outras. Além disso, a interseccionalidade trata da forma como ações e políticas específicas geram opressões que fluem ao longo de tais eixos, constituindo aspectos dinâmicos ou ativos do desempoderamento (CRENSHAW, 2002, p. 177).
}

O gênero é visto como um elemento dentro de uma gama de outros fatores e não é analisado isoladamente como motivador da opressão, mas como elemento dentro de uma intersecção de características que determinam identidades diferentes e subalternidades diversas. A problematização não é mais concentrada em direitos, representatividade ou preconceito contra "a mulher", como entidade abstrata e homogênea, mas contra a "mulher negra", a "mulher imigrante", a "mulher pobre", a "mulher homossexual", a "mulher latina", a "mulher muçulmana", entre tantos outros. 
Segundo Von Flotow (2012), teorias das Ciências Humanas como a interseccionalidade e a queer theory - que combatem o binarismo homem/mulher e busca representar outros grupos, como transgêneros e bissexuais - servem para promover na tradução performances variadas de acordo com a ideia que se deseja reforçar. Essa diversificação pode ocorrer tanto na tradução dentro de uma mesma língua (por tradutores diferentes) como de um mesmo texto para várias línguas:

Cada tradução reivindica o espaço interlocutório, cada tradutor procura ter acesso a ele. Alguns tradutores podem ultrapassar os limites habituais deste espaço, ou podem lutar contra o confinamento que esse espaço impõe. Ainda assim, tomam conta e ocupam o espaço, seja de forma inadequada, fragmentada ou brilhante, proporcionando transformações de novos textos e, com isso, novas possibilidades de leitura e entendimento ${ }^{59}$ (VON FLOTOW, 2012, p. 33).

Apesar do surgimento de teorias e denominações variadas, Von Flotow (2012) defende que o termo global women ("mulheres") continue sendo usado no campo da Tradução Feminista. Ela alerta para o risco de pulverização desse movimento e de dispersão devido à identificação com grupos minoritários. O termo women deveria, segundo ela, continuar a ser usado de forma a manter a unidade dentro da diversidade feminista, e para deixar marcado que os avanços históricos na área da Tradução Feminista foram conquistados por mulheres.

Influenciada pela Filosofia e pela Psicanálise, a Tradução Feminista passou a revisitar e reinterpretar mitos e personagens históricos tradicionalmente relacionados à posição inferior da mulher e da tradução. A análise da personagem mitológica Pandora é um exemplo de mudança de paradigma apresentado por Luce Irigaray. Em vez de ser apresentada como a culpada pelas desgraças que assolam a humanidade por ter aberto a caixa proibida, é retratada como uma figura com "atividade geradora, fecundidade, multiplicidade e produtividade"60 (VON FLOTOW, 2012, p. 5).

A personagem histórica "La Malinche", uma das primeiras mulheres a atuar como tradutora que a história registrou, também tem sido reescrita sob o viés feminista. Von Flotow (1997) explica que ela é apresentada tradicionalmente como a culpada pela queda do Império Asteca por ter servido como tradutora ao conquistador espanhol

\footnotetext{
59 "Every translation claims interlocutory space, every translator seeks access to it. Some translators may overstep the usual bounds of this space, or they may struggle against the confinement this space imposes. Nonetheless, they take up and fill the space, however inadequately, fragmentedly or brilliantly, providing transformances of new texts, and with that, new possibilities of reading and understanding."

60 "generative activity, fruitfulness, multiplicity, creativity and productivity."
} 
Hernán Cortés, no México. Por meio da reescrita feminista, o papel de "La Malinche" deixa de ser o de traidora do seu povo, associada ao personagem bíblico Judas, para ser vista como uma estrategista, uma mediadora hábil que ajudou a evitar uma guerra violenta em uma conquista que aconteceria de qualquer maneira, com ou sem sua participação.

Releituras e retraduções da Bíblia também têm sido feitas por mulheres desde o século XIX, as quais questionam, etimologicamente e culturalmente, dogmas como o da criação da mulher a partir da costela do homem, do fruto proibido e da virgindade de Maria. Ainda hoje, debates e reescritas são feitos sobre o tema, sempre cercados de polêmica. Como afirma Von Flotow (2000, p. 15), trata-se de uma reescrita ideológica do texto, na qual o impulso é por "repensar o status das mulheres na sociedade e estabelecê-lo como igual (lado a lado)". ${ }^{61}$ Nessa escrita ideológica, não se busca manipular o texto, mas, sim, resgatar linguisticamente, a partir dos textos originais e com auxílio de historiadores, trechos que foram omitidos ou erroneamente traduzidos com a finalidade de fundamentar o discurso religioso patriarcal:

\begin{abstract}
Ao longo de centenas de séculos de adaptação e tradução em culturas patriarcais agressivas, esses detalhes haviam desaparecido, esconderam-se e perderam-se, de modo que sistemas sociais e políticos inteiros puderam ser fundados na natureza "secundária" das mulheres: vieram em segundo lugar na Criação, originadas do corpo de Adão, o primeiro humano, e assim por diante $^{62}$ (VON FLOTOW, 2012, p. 129).
\end{abstract}

O resgate e a redescoberta de obras e autoras feministas ocultadas pela tradição histórica também são ações propostas pela Tradução Feminista que têm crescido em importância. Ampliar o conhecimento dessas autoras, como da poetisa galega do século XVII Rosalía de Castro, para além de seus países, permite uma releitura nova e enriquecedora, em outros contextos históricos e culturais. Da mesma forma, há também a proposta de retradução de textos que tenham sido censurados ou cujo conteúdo tenha sido alterado e reduzido, como foi o caso da primeira versão de $O$ segundo sexo, de Simone de Beauvoir, para o inglês, de 1953, retraduzida em versão estendida em 2009.

\footnotetext{
61 "to reconsider the status of women in society and to establish it as equal (side by side)."

62 "Over the hundreds of centuries of adaptation and translation in aggressive patriarchal cultures, these details had disappeared, been hidden and lost, so that entire social and political systems could be founded on the 'secondary' nature of women, coming second in Creation, derived from the body of Adam, the first human, and so on."
} 
A convergência de interesses de vários campos do conhecimento em torno da Tradução Feminista também tem se mostrado um caminho em expansão. O projeto intitulado Translating Feminism: Transfers, Transgression, Transformation, da Escola de Humanidades da Universidade de Glasgow, na Escócia, demonstra essa tendência. ${ }^{63}$ Trata-se de um projeto internacional interdisciplinar em andamento, formado por pesquisadoras de diversas áreas, como História, Antropologia, Literatura, Linguística, Comunicação, Direito e Ciências Sociais, de três continentes, que busca investigar questões sobre circulação e adaptação cultural de textos feministas, sobretudo com motivação política - por quem foram traduzidos, com quais objetivos e para qual público, além de analisar estratégias e práticas empregadas na adaptação do texto e à promoção de encontros culturais.

O projeto busca formar uma rede de pesquisas sobre o papel fundamental da tradução nas conexões transnacionais entre grupos de direitos das mulheres, no intercâmbio de experiências entre esses grupos e em suas demandas por mudanças sociais. Com a finalidade de promover interação e trabalho conjunto, o projeto pretende realizar workshops, divulgar publicações e produzir ferramentas interativas a serem disponibilizadas na Internet.

O primeiro workshop acadêmico do projeto foi realizado em 2016, na Universidade de Glasgow, sobre o tema Translating Feminism: Beyond the Canon (ca. 1945-1990), e o próximo encontro está programado para junho de 2017 em Berne, na Suíça.

No primeiro evento, pesquisadoras debateram temas como a canonização de textos literários feministas - que se tornaram clássicos em âmbito internacional - e a tradução e a recepção/rejeição desses textos em diferentes ambientes culturais.

Também foram apresentadas pesquisas em andamento sobre a importância da tradução para o resgate de autoras feministas relevantes que não foram inseridas do cânone, e para conexões dos continentes americano e europeu com movimentos feministas de diferentes países, como as feministas da Indonésia na década de 1960, grupos feministas em países comunistas e o feminismo islâmico. O papel central da tradução na era atual do feminismo transnacional é um tema muito discutido e investigado nesse projeto.

\footnotetext{
${ }^{63}$ Disponível em: <http://www.gla.ac.uk/schools/humanities/research/historyresearch/researchprojects/translatingfeminis $\mathrm{m} / \# /$ links,contact,background $>$.
} 
Estudos sobre a implantação de livrarias feministas na Europa durante o século $\mathrm{XX}$ - com o intuito de investigar de quem partiram as iniciativas para implantação e manutenção dos locais, quais obras compunham os acervos e tipos de clientes - também têm surgido. Esse é outro vasto campo de pesquisa, ainda pouco explorado, de grande significado para os estudos feministas e da tradução, uma vez que essas bibliotecas eram locais onde ativistas divulgavam suas ideias e tinham contato com outros movimentos pelos direitos das mulheres de outros países, por meio de textos traduzidos.

Outro campo a ser investigado, que tem atraído interesse ainda modesto no campo da Tradução Feminista, é a denominada "paratradução". Se, nos primórdios da atuação da mulher na literatura e na tradução, os paratextos serviam para dar voz e visibilidade à tradutora, hoje, a proposta é de traduzir paratextos a fim de verificar o quanto podem influenciar ou modificar a leitura.

Pelatt (2013) define paratextos como:

qualquer material adicional, anexado ou externo ao texto central, que tenha funções de explicar, definir, instruir ou dar suporte, acrescentar informações históricas ou opiniões e ações relevantes de estudiosos, tradutores e revisores $^{64}$ (PELATT, 2013, p. 7).

Para a autora, o conteúdo dos paratextos jamais pode ser considerado neutro ou imparcial, uma vez que carregaria a visão subjetiva de todos os sujeitos envolvidos.

Pelatt (2013) explica que as categorias de paratextos podem ser divididas em duas: verbais - prefácio, introdução, nota de rodapé, nota de fim e epílogo; e não verbais - capa, sobrecapa, sumário, índice, ilustrações, tabelas e gráficos, layout, parágrafos, fontes. Para além da autoria compartilhada entre autor e tradutor, editores, revisores, e os próprios leitores, com seus discursos culturais preexistentes, transformam a obra e dão a ela múltiplos significados e interpretações por meio dos paratextos.

Um exemplo de pesquisa recente sobre Tradução Feminista de paratextos ou feminist paratranslation é o estudo de Abou Rached (2017) sobre a tradução de escritoras iraquianas feministas para o inglês após 2003. A análise da forma como foi feita a tradução (editora, tradutores selecionados), a visão política transmitida pelos paratextos, os comentários inseridos, o "pré-conceito" que leitores norte-americanos carregavam sobre o Iraque e as mulheres iraquianas, são investigados de forma a

\footnotetext{
64 “ $[\ldots]$ any material additional to, rpended to or external to the core text which has functions of explaining, defining, instructing, or supporting, adding background information, or the relevant opinions and attitudes of scholars, translators and reviewers."
} 
verificar de que maneira essa publicação afetou a recepção da obra nos Estados Unidos e a produção feminista ativista no país de origem.

Essas linhas de pesquisa demonstram o poder "transformativo e transgressivo" da tradução, ao revelar outras realidades e outras possibilidades de arranjos sociais e culturais, e fazem da tradução um agente promotor de mudanças. Ao conhecer outras realidades e, simultaneamente se fazer conhecido, o contato com "o outro" incita à análise crítica da realidade e ao questionamento de normas e opressões impostas.

A multidisciplinaridade tende a tornar a Tradução Feminista ainda mais frutífera e fazer dela um campo ainda mais fértil para pesquisas, e a tornar a prática tradutória mais reflexiva. Na tradução de obras literárias feministas, ao refletir sobre a subjetividade e o poder transformativo que envolvem o seu trabalho, a tradutora (e o tradutor) pode evitar o reducionismo, o "achatamento" do conteúdo dessa obra na língua de chegada. Na tradução de autoras feministas contemporâneas como Chimamanda, uma tradutora (ou um tradutor) que tenha consciência da ideologia, da temática trabalhada e do background da escritora, e que tenha o esforço consciente de manter a proposta feminista no texto de chegada, certamente contribuirá para uma recepção mais próxima àquela proposta pela autora aos leitores do texto de partida.

É importante perceber que, assim como as conquistas pelas quais lutam as feministas, as conquistas da Tradução Feminista ainda não estão consolidadas. Ainda que sem a unanimidade de outros tempos, permanece a premissa de fidelidade e de submissão ao homem, assim como ao texto de partida. A tradução continua sendo secundária, e o sujeito-tradutor continua, muitas vezes, silenciado e oculto atrás de regras editoriais, às quais não somente textos feministas estão sujeitos.

Questionar essas regras, os limites impostos à voz da tradução e a busca pelo ideal (inexistente) de neutralidade, é de suma importância, tanto para revisitar, sob outro prisma, fatos históricos, mitos e textos de escritoras feministas e suas traduções, como para descobrir e resgatar obras e escritoras importantes para o movimento feminista que caíram no esquecimento, além de assegurar uma tradução consciente, sem “achatamentos" para produções de autoras atuais, como é o caso de Chimamanda.

Uma tradução sem essa consciência de manter a proposta ideológica e o projeto literário da escritora traz o risco de diminuir a receptividade dela no país, ou de inserir sua obra dentro de um gênero literário menor, inferiorizado, chamado, pejorativamente, de "literatura de mulherzinha" ou chick-lit, em inglês. É necessário atentar para esse risco, principalmente tratando-se de uma escritora jovem que, provavelmente, ainda 
escreverá muitos livros. Como visto nesta dissertação, no caso específico de Purple hibiscus, empoderar a tradutora é mudar o viés da fidelidade, deixando de lado a literalidade para manter-se fiel aos ideais feministas de Chimamanda.

Finalmente, ressalto que as propostas da Tradução Feminista aqui elencadas podem ser adotadas não apenas para traduções de textos feministas escritos e traduzidos por mulheres, mas também por traduções de textos de temas diversos, independentemente do sexo de quem traduz. A reflexão sobre o projeto literário do autor (ou da autora), a consciência da importância de manutenção desse projeto e a liberdade na atividade tradutória para manipular o texto, juntamente com a possibilidade de dialogar com o leitor e com a leitora tanto por meio de uma introdução como por notas inseridas ao longo do texto, certamente serão enriquecedoras em outras áreas.

Meu desejo é que esta pesquisa venha a contribuir para a reflexão, e que desperte interesse para pesquisas futuras, tanto na área de Estudos da Tradução como na de Estudos Literários. Sobretudo no Brasil, onde o pouco que se fala sobre a Tradução Feminista ainda está ligado às propostas pioneiras da escola canadense e pesquisas multidisciplinares, como as realizadas atualmente em outros países, teriam uma grande contribuição a oferecer, tanto para a leitura como para a releitura de autoras estrangeiras traduzidas no país como para a tradução de autoras brasileiras, promovendo o seu florescer no cenário literário internacional. 


\section{REFERÊNCIAS BIBLIOGRÁFICAS}

ABOU RACHED, Ruth. Feminist paratranslation as literary activism: Iraqi writeractivist Haifa Zangana in the Post-2003 US. In: CASTRO, Olga; ERGUN, Emek (Ed.). Feminist Translation Studies: local and transnational perspectives. London: Routledge, 2017. No prelo.

ALVES, Branca Moreira; PITANGUY, Jacqueline. O que é feminismo. São Paulo: Brasiliense, 1985.

ANCHIETA, Amarílis Macedo Lima Lopes de. Tongue-tied: traduzindo os contos em guerra de Chinua Achebe. 2014. 194 f. Dissertação. (Mestrado em Estudos da Tradução) - Brasília: Departamento de Línguas Estrangeiras e Tradução, Universidade de Brasília, Brasília, 2014.

ANCHIETA, Amarilis; PEREIRA, Fernanda A. Things fall apart as published in Brazil: searching for a mouth with which to tell the story. In: KOBUS, Marais; FEINAUER, Ilse (Ed.). Translation Studies beyond the postcolony. Newcastle upon Tyne, UK: Cambridge Scholars Publishing, UK, 2017. p. 242-262.

ARROJO, Rosemary. Feminist, "orgasmic" theories of translation and their contradictions. Tradterm, São Paulo, v. 2, p. 67-75, dec. 1995. Disponível em: <http://www.revistas.usp.br/tradterm/article/view/49916>. Acesso em: 02 fev. 2017.

BAILEY, Cristina Ferreira-Pinto. Künstlerroman: a mulher artista e a escrita do ser. Rev. Estud. Fem., Florianópolis , v. 13, n. 2, p. 444-446, Aug. 2005. Disponível em <http://www.scielo.br/scielo.php?script=sci_arttext\&pid=S0104-

026X2005000200020\&lng=en\&nrm=iso>. Acesso em: 02 fev. 2017.

BARROS, Raquel da S. O púrpura e a lavanda: o womanism em A cor púrpura de Alice Walker. Revista África e Africanidades, ano IV, n. 14/15, ago.-nov. 2011.

BASSNETT, Susan. Writing in no man's land: questions of gender and translation. Ilha do Desterro a Journal of English Language, Literatures in English and Cultural Studies, Florianópolis, n. 28, p. 63-74, jan. 1992. Disponível em: <https://periodicos.ufsc.br/index.php/desterro/article/view/8751/10654>. Acesso em: 02 fev. 2017.

BRYCE, Jane. "Half and half children": third-generation women writers and the new Nigerian novel. Research in African Literatures, v. 39, n. 2, p. 49-67, 2008.

CAMPOS, Giovana C. Estudos da Tradução e Análise do Discurso: diálogos possíveis. In: CÍRCULO FLUMINENSE DE ESTUDOS FILOLÓGICOS - Congresso Nacional de Linguística e Filologia, Universidade Estadual do Rio de Janeiro/RJ, v. XII, n. 12, 2008.

CHAMBERLAIN, Lori. Gender and the metaphorics of translation. Signs, v. 13, n. 3, p. 454-472, 1988. Published by: The University of Chicago Press URL: Disponível em: <http://www.jstor.org/stable/3174168>. Acesso em: 02 fev. 2017. 
CRENSHAW, Kimberlé. Documento para o encontro de especialistas em aspectos da discriminação racial relativos ao gênero. Estudos Feministas, Florianópolis, v. 10, n. 1, p. 171-188, jan. 2002. Disponível em: 〈http://www.scielo.br/pdf/ref/v10n1/11636.pdf>. Acesso em: 02 fev. 2017.

DICIONÁRIO DE CAMBRIDGE. Disponível em: <http://dictionary.cambridge.org>. Acesso em: 02 fev. 2017.

DÉPÊCHE, Marie-France. A tradução feminista: teorias e práticas subversivas Nísia Floresta e a Escola de Tradução canadense. Textos de História, Universidade de Brasília - UnB, v. 8, n. 1/2, 2000.

GARNER, Claire. "Profile of Chimamanda Ngozi Adichie" P.S. (Afterword). In: ADICHIE, Chimamanda Ngozi. Purple hibiscus. London: Harper, 2005 (versão digital).

GOROVITZ, Sabine; MARTÍNEZ, Susana. Verbete "Diglossia". In: CAVALCANTI, L.; TONHATI, T.; BOTEGA, T. Criminalização das migrações. In: Dicionário crítico sobre migrações internacionais. [s.L.: s.n.e., s.d.].

HUDSON-WEEMS, Clenora, Africana womanism: reclaiming ourselves. Troy, Mich.: Bedford Publishers, 1993.

JAMES, Kate. Speaking in the feminine: considerations for gender-sensitive. Translation, v. 16, n. 2, abr. 2011. Disponível em: <http://translationjournal.net/journal/56feminine.htm>. Acesso em: 02 fev. 2017.

MANUAL DE REDAÇÃO E ESTILO DA COMPANHIA DASLETRAS. Versão eletrônica. São Paulo: Editora Schwarcz S.A., 2012.

NUNES, Alyxandra Gomes. Things fall apart de Chinua Achebe como romance de fundação da literatura nigeriana em língua inglesa. - 2005. Dissertação (Mestrado em Teoria e História Literária) - Campinas: Instituto de Estudos da Linguagem - IEL, Universidade de Campinas, SP, 2005.

NUNES, Alyxandra Gomes. História, etnicidade e memória da guerra de Biafra (196770) na poesia de Chinua Achebe e na prosa de Chimamanda Ngozi Adichie em Half a yellow sun. In: XI Congresso Internacional da ABRALIC Tessituras, Interações, Convergências 13 a 17 de julho de 2008 USP São Paulo, Brasil. Disponível em: <http://www.abralic.org.br/eventos/cong2008/AnaisOnline/simposios/pdf/024/ALYXA NDRA_NUNES.pdf >. Acesso em: 02 fev. 2017.

OGUNYEMI, Chikwenye Okonjo. Womanism: the dynamics of the contemporary black female novel in English. Signs, v. 11, n. 1 p. 63-80, 1985.

PAVLIC, Brenda (Ed.). Guidelines on Gender-Neutral Language UNESCO, 1999. Disponível em: <http://unesdoc.unesco.org/images/0011/001149/114950mo.pdf>. Acesso em: 02 fev. 2017.

PELLATT, Valerie (Ed.). Text, extratext, metatext and paratext in translation. Newcastle upon Tyne: Cambridge Scholars Publishing, Inglaterra, 2013. 
PEREIRA, Fernanda Alencar. Literatura e política: a representação das elites póscoloniais africanas em Chinua Achebe e Pepetela. Tese (doutorado) - Universidade Federal de Minas Gerais, Faculdade de Letras, Programa de Pós-Graduação em Estudos Literários, Université Européenne de Bretagne/Rennes, École Doctorale Arts, Lettres, Langues, 2012.

SIMON, Sherry. Gender in translation. London: Routledge, 1996.

SOMMER, Doris. Resistant texts and incompetent readers. Poetics Today, v. 15, p. 2-3, 1994.

SOUSA, Germana H. P.; COSTA, Patrícia R. O lugar da literatura nos cursos de Tradução. In: SOUSA, Germana H. P. (Org.). História da Tradução: ensaios de teoria, crítica e tradução literária. Campinas, SP: Pontes Editores, 2015. p. 157-173. (col. Estudos da Tradução, v. 1).

SPIVAK, Gayatri Chakravorty. Pode o subalterno falar?. Trad. Sandra Regina Goulart Almeida; Marcos Pereira Feitosa; André Pereira. Belo Horizonte: Editora UFMG, 2010.

TELEGA-SOARES, Natalia. "E ouviram-se as vozes de mulheres africanas...": o feminismo africano e a escrita de Chimamanda Ngozi Adichie. Dissertação de Mestrado em Estudos sobre as Mulheres - As Mulheres na Sociedade e na Cultura. Faculdade de ciências sociais e humanas - Universidade Nova de Lisboa, 2014.

THE DANGER OF A SINGLE STORY [O perigo de uma única história]. Disponível em:

$<$ https://www.ted.com/talks/chimamanda_adichie_the_danger_of_a_single_story?langu age $=$ pt-br $>$.Acesso em: 02 fev. 2017.

TUNCA, Daria. Ideology in Chimamanda Ngozi Adichie's Purple hibiscus. English Text Construction, v. 2, n. 1, p. 121-131, 2009.

VERONESI, Raquel Barros. A reescritura das personagens "womanistas" de The color purple para o cinema / Raquel Barros Veronesi. - 2015. 158 f. : il. color., enc. ; $30 \mathrm{~cm}$. Dissertação (mestrado) - Universidade Federal do Ceará, Centro de Humanidades, Departamento de Literatura, Programa de Pós-Graduação em Letras, Fortaleza, 2015.

VON FLOTOW, Luise. Feminist Translation: contexts, practices and theories. TTR: Traduction, Terminologie, Rédaction, v. 4, n. 2, 1991, p. 69-84, 1991. Disponível em: <http://id.erudit.org/iderudit/037094ar>. Acesso em: 02 fev. 2017.

VON FLOTOW, Luise. Women, Bibles, Ideologies. TTR: Traduction, Terminologie, Rédaction, v. 13, n. 1, p. 9-20, 2000. Disponível em: <http://id.erudit.org/iderudit/037390ar>. Acesso em: 02 fev. 2017.

VON FLOTOW, Luise. Contested gender in translation: intersectionality and metramorphics. Palimpsestes, v. 22, 2009, Ed. Presses Sorbonne Nouvelle. Disponível em: 〈http://palimpsestes.revues.org/211〉. Acesso em: 02 fev. 2017. 
VON FLOTOW, Luise. Translating Women: from recent histories and re-translations to "queerying" translation, and metramorphosis. Quaderns. Revista de Traducción, Barcelona, v. 19, p. 127-139, 2012.

VON FLOTOW, Luise. Translation and gender: translating in the "era of feminism". Ottawa: University of Ottawa Press, 1997.

WALKER, Alice. In Search of our mother's gardens. New York: Harcourt Books, 1983.

WE SHOULD ALL BE FEMINISTS [Todos devemos ser feministas]. Discurso Chimamanda Ngozi Adichie. Disponível em: <https://www.youtube.com/watch?v=hg3umXU_qWc>. Acesso em: 02 fev. 2017.

\section{CORPUS LITERÁRIO DA OBRA DE CHIMAMANDA NGOZI ADICHIE}

ADICHIE, Chimamanda Ngozi. For love of Biafra. Ibadan: Spectrum Books, 1998.

ADICHIE, Chimamanda Ngozi. Half of a yellow sun. London: Fourth Estate, 2006.

ADICHIE, Chimamanda Ngozi. Hibisco roxo. Tradução de Júlia Romeu. São Paulo: Companhia das Letras, 2016.

ADICHIE, Chimamanda Ngozi. Meio sol amarelo. Tradução de Beth Vieira. São Paulo: Companhia das Letras, 2008.

ADICHIE, Chimamanda Ngozi. Purple hibiscus. London: Fourth Estate, 2004. (versão digital).

ADICHIE, Chimamanda Ngozi. Sejamos todos feministas. Tradução de Christina Baum. São Paulo: Companhia das Letras, 2015.

ADICHIE, Chimamanda Ngozi. Para educar crianças feministas - um manifesto Tradução de Denise Bottman. São Paulo: Companhia das Letras, 2017 


\section{APÊNDICE}

\section{ENTREVISTAS COM A TRADUTORA JÚLIA ROMEU}

\section{Resposta enviada por e-mail em 19 de outubro de 2015}

\section{SOBRE O SUJEITO-TRADUTOR}

1. Pesquisando na Internet, vi que você é graduada em Jornalismo. Como você se enveredou pelos caminhos da tradução?

JÚLIA ROMEU: Sempre tive facilidade para aprender línguas, e, desde que morei nos Estados Unidos, na adolescência, sou fluente em inglês. Ainda na faculdade, comecei a traduzir artigos para a revista Seleções. Dessa maneira, pude treinar com textos menores antes de passar para os livros. Minha mãe, a escritora Heloisa Seixas, tinha alguma experiência como tradutora e me ajudou bastante no começo, revisando meus textos. Aos 23 anos, traduzi meu primeiro livro. Depois disso, não parei mais. Fui me apaixonando pela tradução e acabei me tornando mais tradutora do que jornalista, apesar da minha formação não ter sido na área.

2. Você também é escritora? Que tipo de textos escreve? Já publicou/tem intenção de publicar um livro?

JÚLIA ROMEU: Sou, sim. Escrevi, junto com Heloisa Seixas, duas peças (Era no tempo do rei, de 2010, e Bilac vê estrelas, que estreou este ano) e uma biografia de Carmen Miranda para crianças (Carmen, a grande pequena notável, publicada em 2014 pela Edições de Janeiro e ganhadora do Prêmio FNLIJ 2015 de Melhor Livro Informativo). E tenho alguns contos na gaveta, só meus, que espero publicar em breve.

3. Por favor, fale um pouco sobre sua experiência com o teatro.

JÚLIA ROMEU: Eu e minha mãe tivemos a ideia de começar a escrever musicais em 2007, quando muitas peças desse tipo estavam estreando aqui no Rio. Durante o processo de escrita do livro do meu padrasto, o Ruy Castro, de sua biografia da Carmen Miranda, Carmen: uma biografia (Companhia das Letras, 2005), nós também nos apaixonamos pela personagem, e quisemos fazer uma peça que mostrasse o lado menos conhecido dela, os 10 anos durante os quais foi considerada a maior cantora do Brasil, 
antes de partir para os Estados Unidos. O repertório dessa época é maravilhoso, com muitas músicas que a maioria das pessoas conhece, mas não sabe que foram lançadas por Carmen, e isso também nos incentivou. Escrevemos a peça, mas não conseguimos patrocínio para encenar. Quando estávamos tentando, o compositor Carlinhos Lyra deu a ideia de transformarmos o romance do Ruy, Era no tempo do rei, num musical, que foi encenado em 2010, com direção de João Fonseca, músicas do próprio Lyra e letras de Aldir Blanc. Como nos apaixonamos pela experiência, adaptamos também o outro romance do Ruy, Bilac vê estrelas, para os palcos, e ele ganhou letra e música de Nei Lopes. A peça também foi dirigida por João Fonseca e esteve em cartaz este ano [2017] no Sesc Ginástico, no Teatro dos Quatro, e no Espaço Promon, em São Paulo. Semana passada, ganhamos o prêmio Bibi Ferreira de Melhor Música Original e Melhor Musical Brasileiro. Eu e minha mãe já escrevemos uma quarta peça, para a qual buscamos patrocínio, e estamos planejando uma quinta.

4 No seu blog, vi que você já traduziu várias obras literárias de autoria feminina, como Charlotte Brontë e Jane Austen. De quem partiu a iniciativa dessas traduções? Você escolheu essas obras por algum motivo especial?

JÚLIA ROMEU: Sou completamente apaixonada por Jane Austen e as duas obras da autora que traduzi partiram de iniciativa minha. Em 2010, sugeri à Best Bolso a tradução de A abadia de Northanger, um livro que amo e que, na época, só tinha sido traduzido para o português do Brasil por Ledo Ivo. Não havia nenhuma edição daquela tradução disponível em livrarias, portanto, quem quisesse ler em português teria que procurá-la nos sebos ou ler em português de Portugal. Vendo o meu entusiasmo, a Silvia Leitão, editora da Best Bolso, me chamou também para fazer os prefácios dos cinco outros romances da autora, que foram lançados numa coleção pela editora. Com a Juvenília foi a mesma coisa: li a edição da Penguin dos escritos de infância da Jane Austen e da Charlotte Brontë e quis ajudar a torná-los disponíveis para os leitores brasileiros. Sugeri a tradução para a Penguin/Companhia das Letras, e eles toparam. Foi minha paixão por Jane Austen, entre outras coisas, que me levou a entrar no Mestrado de Literaturas de Língua Inglesa da UERJ, onde estou escrevendo uma dissertação sobre o viés feminista da obra dela.

\section{SOBRE O PROJETO DE TRADUÇÃO DE PURPLE HIBISCUS}

\section{Como você foi designada para ser a tradutora da obra?}


JÚLIA ROMEU: Eu já tinha feito algumas traduções para a Companhia das Letras e alguém me chamou para fazer o Purple hibiscus. Não conhecia a obra da Chimamanda e, realmente, não sei por que me escolheram.

2. O que você sabia sobre a autora/sobre o livro anteriormente?

JÚLIA ROMEU: Nada! A Chimamanda era muito menos conhecida naquela época. Fui pesquisar depois que me pediram para fazer o livro.

3. Half of a yellow sun foi o segundo romance de Chimamanda Adichie, mas o primeiro a ser traduzido no Brasil. Você já havia lido essa obra antes de Purple hibiscus? (Se sim, em português ou inglês?)

JÚLIA ROMEU: Antes de traduzir o Purple hibiscus, comprei e li o original de Half a yellow sun e dei uma pesquisada na tradução para português, embora não tenha lido inteira.

4. Antes ou durante a tradução de Purple hibiscus, você fez algum tipo de pesquisa sociológica, cultural, geopolitica, histórica, etc. sobre a Nigéria?

JÚLIA ROMEU: Sim, entrei em vários blogs sobre a Nigéria para aprender sobre a história, a geografia, a cultura do Brasil e a cultura igbo, à qual pertencem a autora e seus personagens no livro.

5. Ao traduzir Purple hibiscus, você leu a tradução feita para o português de Portugal, A cor do hibisco, publicada em 2010?

JÚLIA ROMEU: Não.

6. Quanto tempo você levou para traduzir o livro? Qual o prazo dado pela editora? Você considera que foi suficiente?

JÚLIA ROMEU: Não me lembro exatamente. Em geral, tenho cerca de cinco meses para traduzir um livro. Considero que foi suficiente, sim.

7. Por que não há prefácio ou introdução no início do livro, nem notas do tradutor ao longo do romance, ou outros paratextos em Hibisco roxo? Foi uma opção sua ou da editora? 
JÚLIA ROMEU: Foi uma opção da editora. A Companhia das Letras tem como regra não colocar notas do tradutor em obras de ficção. É claro que existem exceções, mas eles pedem que nós evitemos ao máximo.

\section{Respostas enviadas por e-mail em $1^{0}$ de maio de 2016}

\section{SOBRE A TRADUÇÃO DE AMERICANAH}

1. Qual foi o processo para que você fosse a tradutora designada para traduzir o romance? O fato de ter sido a tradutora de Purple hibiscus teve algum peso nessa escolha, tanto para você quanto para a editora?

JÚLIA ROMEU: Não posso responder pela editora. Para mim teve um peso, sim. Como eu tinha adorado traduzir Purple hibiscus, fiquei muito feliz com a oportunidade de traduzir Americanah.

2 Quanto tempo você levou para traduzir Americanah? Qual o prazo estabelecido pela editora? Você considera que foi suficiente?

JÚLIA ROMEU: Não me lembro exatamente, mas foi um prazo relativamente longo, já que o livro é extenso. Foi suficiente, sim.

$3 \quad$ Você estabeleceu previamente um projeto de tradução do livro?

JÚLIA ROMEU: O que faço é ler o livro todo e começar a identificar os pontos que acho que serão mais problemáticos. Começo a traduzir o livro já dando atenção a esses pontos. Se não encontro uma solução satisfatória, sigo em frente e vou voltando a eles, pois a solução, muitas vezes, aparece naturalmente com o trabalho.

4. Você buscou saber mais sobre a autora, sobre o livro e sobre os temas que ele trata, antes de iniciar a tradução?

JÚLIA ROMEU: Eu já sabia bastante sobre a autora, por tê-la traduzido e trabalhado com ela no Mestrado em Literaturas de Língua Inglesa da UERJ que já estava fazendo na época em que traduzi o Americanah. Pesquisei sobre a geografia de Lagos e sobre alguns aspectos da cultura nigeriana e americana que desconhecia.

5. Como você traduziu também o primeiro romance de Chimamanda, ao traduzir Americanah, você conseguiu identificar semelhanças entre os dois livros (marcas de 
estilo da escritora, na linguagem, nas narrativas, ou quaisquer marcadores que se repetem em ambas as obras)?

JÚLIA ROMEU: Eu acho as duas obras bastante diferentes. Em Purple hibiscus a linguagem é mais formal; é um inglês de uma menina nigeriana de classe alta, um inglês com tintas britânicas. Já em Americanah, o inglês é mais contemporâneo e americano. Acredito que isso se deva ao fato de que Purple hibiscus é narrado em primeira pessoa pela protagonista Kambili, reproduzindo o inglês que ela falaria, enquanto Americanah, além de ser narrado na terceira pessoa, fala bastante do universo dos Estados Unidos. Talvez tenha sido uma escolha deliberada da autora; talvez, em parte, seja fruto da própria mudança no vocabulário dela, já que ela agora passa parte do tempo morando nos Estados Unidos.

\section{A TRADUTORA}

1. O que é tradução, para você?

JÚLIA ROMEU: A tradução pode ser muitas coisas, pois sua função muda de acordo com o que está sendo traduzido e para quem está sendo traduzido. Na tradução literária, acredito que a função é levar o espírito de uma obra de arte para o público leitor que não tem possibilidade de lê-la no original. É um trabalho de grande responsabilidade, sempre imperfeito, a ser feito em parte com o cérebro, em parte com a alma.

2. Como você se posiciona quanto à questão da fidelidade ao texto de partida e à liberdade de manipulação do texto pelo tradutor?

JÚLIA ROMEU: Não existe uma fórmula fixa. Acho que devemos nos manter sempre os mais fiéis possíveis, mas o que é ser "fiel"? A tradução literal pode ser fiel às palavras usadas no original, mas deforma a mensagem. É preciso decidir o que fazer a cada caso. E mudar de ideia é inevitável.

\section{A TRADUTORA, CHIMAMANDA E O FEMINISMO}

1. Você se considera feminista?

\section{JÚLIA ROMEU: Sim.}


JÚLIA ROMEU: Feminismo é acreditar que as mulheres não são inferiores aos homens, e que, portanto, devem ser tratadas como iguais e terem as mesmas liberdades e oportunidades.

1. Você conhece a postura de Chimamanda Adichie como ativista pró-feminismo e da cultura nigeriana? (Caso a resposta seja afirmativa, quando/como você tomou conhecimento da ideologia da escritora?)

JÚLIA ROMEU: Depois que li Purple hibiscus, fui procurar saber mais sobre a Chimamanda na Internet, e a primeira coisa que encontrei foi a palestra "O perigo de uma única história". Ali, já fica clara sua posição em defesa da cultura nigeriana, ou melhor dizendo, da multiplicidade de culturas. Sua posição em relação ao feminismo, descobri depois; não me lembro quando.

2. Você consegue identificar alguns traços de feminismo nas obras que traduziu, para além dos personagens (marcas linguísticas, traços sintáticos, etc.)?

JÚLIA ROMEU: Para mim, a principal marca do feminismo nas obras que traduzi está mesmo nas personagens femininas e na maneira como elas são retratadas. A submissão de Kambili e de sua mãe, em Purple hibiscus, contrastada com a independência e força da tia Ifeoma; e a representação de Ifemelu em Americanah, outra mulher forte, com opiniões que incomodam, muitas vezes desconcertam, os homens da sua vida.

\section{Resposta enviada por e-mail em 04 de janeiro de 2017}

1 Você chegou a elaborar (ou talvez tenha recebido de alguém, ou da editora) um glossário dos termos em igbo, ou de termos da cultura nigeriana ou coisas do tipo, para auxiliar na tradução dos livros da Chimamanda? Se sim, você poderia nos mostrar e dar informações? Se não, por quê? E acha que fez falta no trabalho tradutório?

JÚLIA ROMEU: Não, não elaborei. Acredito que a Chimamanda, assim como muitos autores que falam línguas pouco conhecidas pelo grande público, deixou alguns termos em igbo sem tradução propositalmente, para causar uma estranheza no leitor com a presença deles ali. Na época, procurei a tradução de alguns por curiosidade e para melhor compreensão da obra como um todo, mas não tinha uma fonte confiável e não considerei a hipótese de incluir as traduções que encontrei na edição. 
ANEXOS - IMAGENS

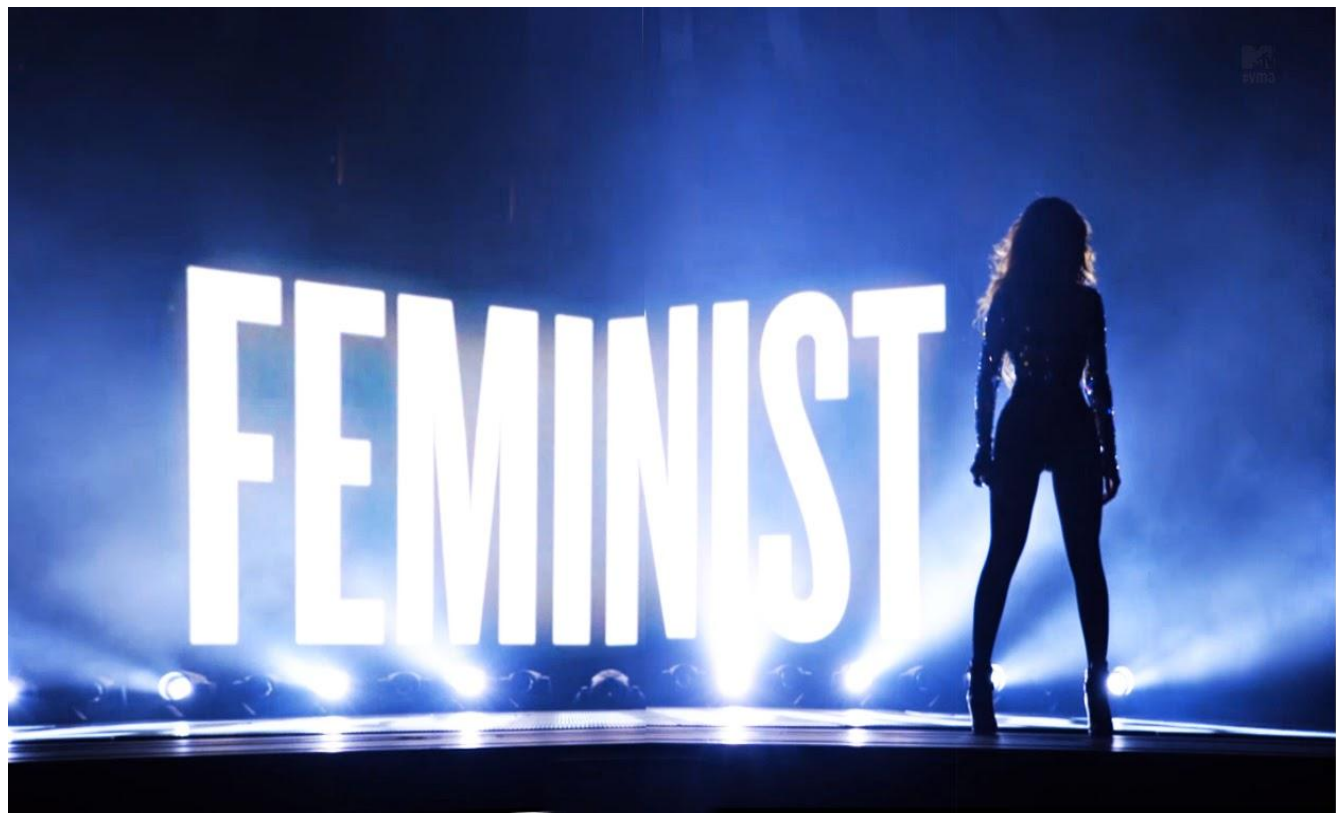

Imagem 1: Apresentação da cantora Beyoncé no 2014 MTV VMAs.

Fonte: 〈http://www.mtv.com/news/1910270/beyonce-2014-vma-perfomance/> (Acesso em 01 de fevereiro de 2017)

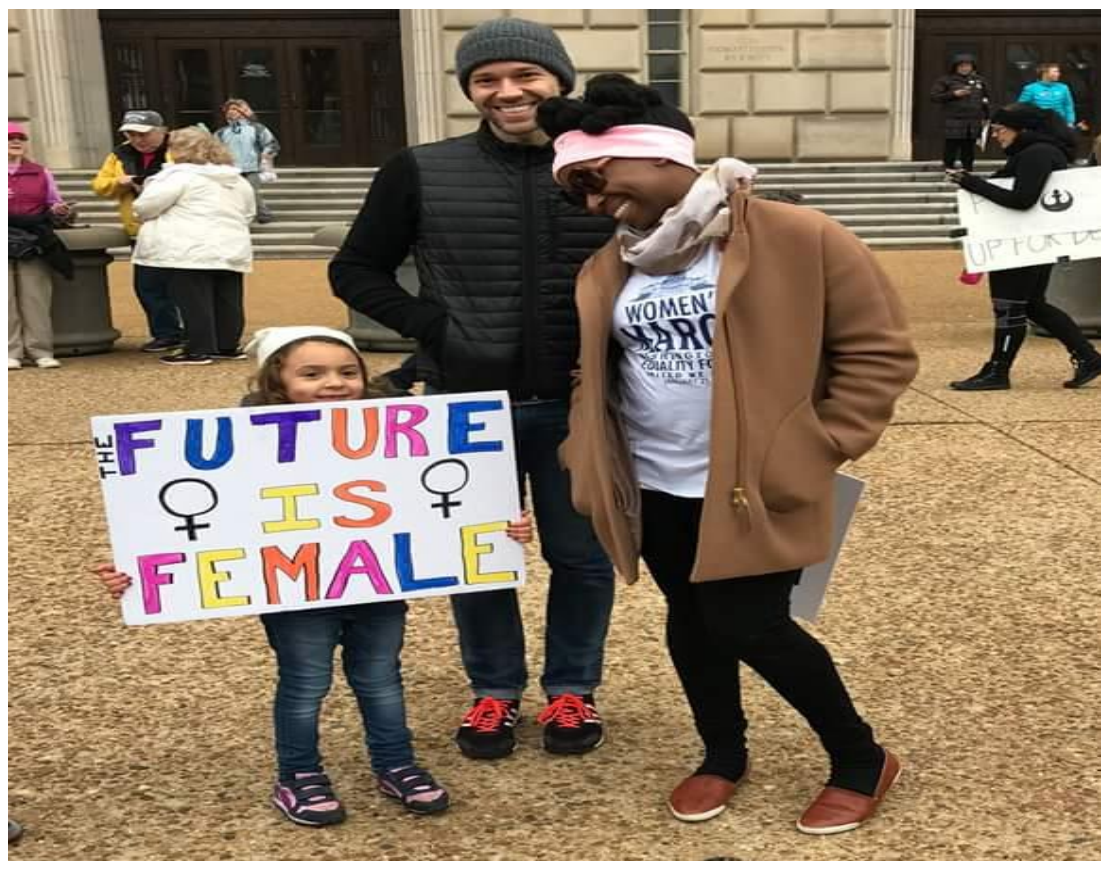

Imagem 2: Chimamanda durante a Women's March on Washington, em 21/01/2017.

Fonte: <http://www.lindaikejisblog.com/2017/01/photos-of-chimamanda-ngozi-adichie-at.html>. (Acesso em 01 de fevereiro de 2017) 


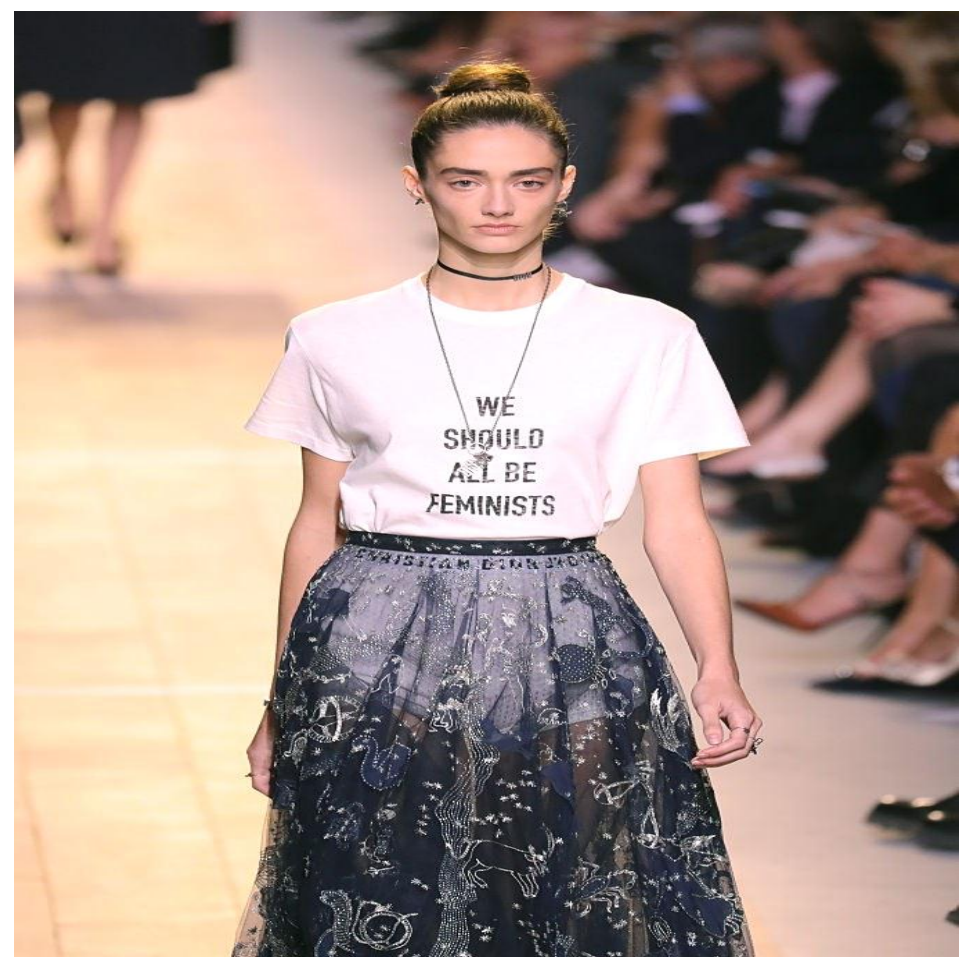

Imagem 3: Desfile de estreia de Maria Grazia Chiuri para Dior, em setembro/2016.

Fonte: <http://www.okayafrica.com/in-brief/chimamanda-ngozi-adichie-dior-maria-grazia-chiuri-parisfashion-week/> (Acesso em 01 de fevereiro de 2017).

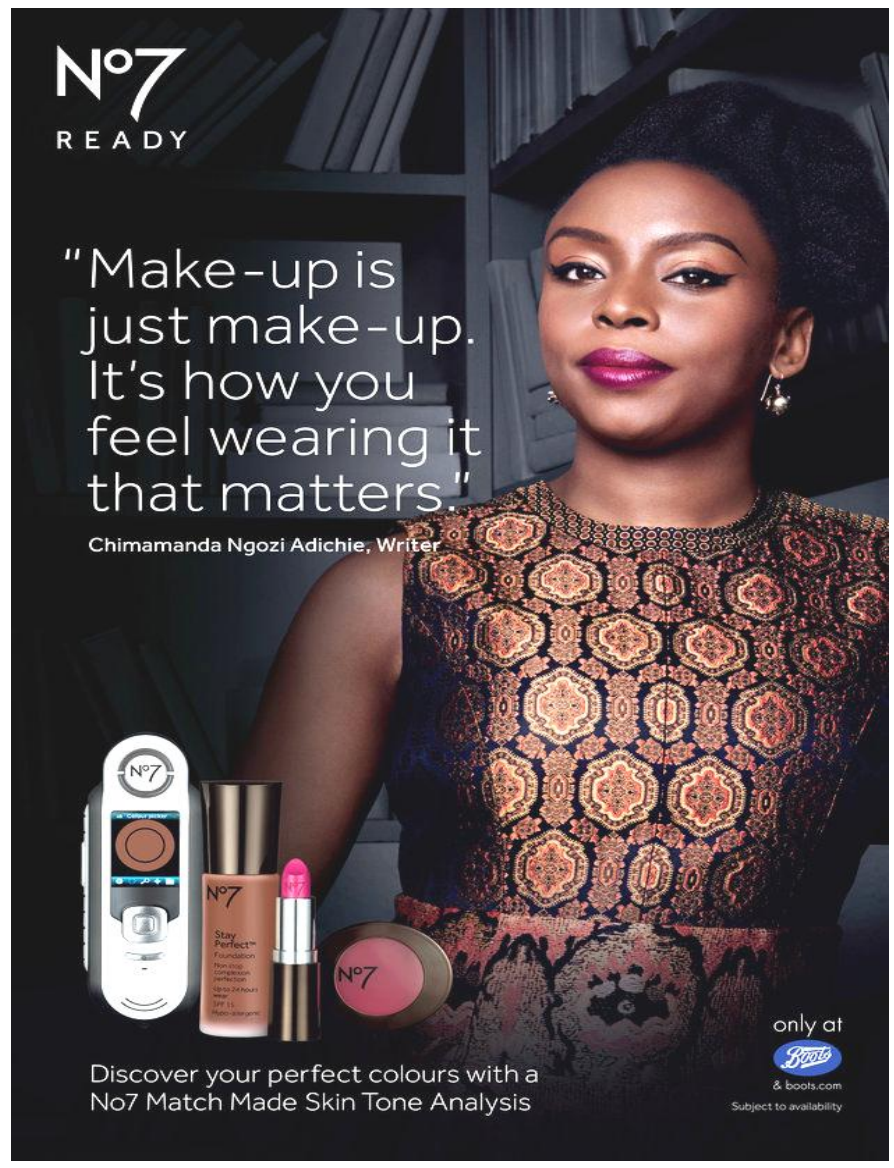

Imagem 4: Anúncio da linha No. 7, da marca inglesa de cosméticos Boots.

Fonte: <http://www.forbes.com/sites/karenhua/2016/10/21/the-cultural-importance-of-chimamanda-ngoziadichies-boots-beauty-campaign/>. (Acesso em 01 de fevereiro de 2017) 